AUTARQUIA ASSOCIADA À UNIVERSIDADE DE SÃO PAULO

\title{
A FLEXIBILIZAÇÃO DA COMPETÊNCIA E DO PROCESSO NORMATIVO EM RELAÇÃO À SEGURANÇA E A PROTEÇÃO RADIOLÓGICA
}

\author{
VANESSA DA ANA
}

\begin{abstract}
Dissertação apresentada como parte dos requisitos para obtenção do Grau de Mestre em Ciências na Área de Tecnologia Nuclear - Aplicações
\end{abstract}

Orientador:

Prof. Dr. Gian Maria Agostino Angelo Sordi 


\title{
INSTITUTO DE PESQUISAS ENERGÉTICAS E NUCLEARES
}

Autarquia associada à Universidade de São Paulo

\section{A FLEXIBILIZAÇÃO DA COMPETÊNCIA E DO PROCESSO NORMATIVO EM RELAÇÃO À SEGURANÇA E A PROTEÇÃO RADIOLÓGICA}

\author{
VANESSA DA ANA
}

Dissertação apresentada como parte dos
requisitos para obtenção do Grau de
Mestre em Ciências na Área
de Tecnologia Nuclear-Aplicações

Orientador:

Prof. Dr. Gian Maria Agostino angelo Sordi

Versão Corrigida

Versão Original disponível no IPEN

São Paulo

2016 


\section{DEDICATÓRIA}

A Deus e a Nossa Senhora de Aparecida pelo dom da vida que me concedeu e por ter me iluminado o meu caminho durante todos estes anos.

À minha família, meus pais Mário e Marta e minha irmã Patrícia, que no decorrer da minha vida, proporcionaram-me, além de extenso carinho e amor, os conhecimentos da integridade, da perseverança e de procurar sempre em Deus à força maior para o meu desenvolvimento como ser humano. Por essa razão e pelos sacrifícios consentidos durante a minha formação é que dedico e reconheço a vocês, minha imensa gratidão e sempre amor.

Ao Marcelo, meu esposo, por ter me dado asas que me fizeram voar e por ter acreditado que nenhuma estrela estava fora de alcance. 


\section{AGRADECIMENTOS}

Á Universidade de São Paulo por promover todas as formas de conhecimento através da pesquisa, do ensino e da aprendizagem.

Ao Instituto de Pesquisas Energéticas e Nucleares pelos ensinos transmitidos de forma interdisciplinar, pela oportunidade de convivência com profissionais de competência inigualáveis e pela infraestrutura e tecnologia colocados a disposição da presente pesquisa.

A Anhanguera Educacional S.A., pelo auxílio, suporte financeiro e apoio concedido, que foi de fundamental importância para o desenvolvimento deste trabalho.

Ao Prof. Dr. Gian Maria Agostino Angelo Sordi, pessoa dedicada, honesta, competente, carinhosa, grande docente e profissional com a qual tenho muito orgulho e muita honra de ser aluna. Obrigada por tudo, pela orientação, paciência, confiança, dedicação na execução desse trabalho e principalmente pelo seu amor fraternal que será eterno. Seu exemplo motiva e engrandece muito!

Ao Prof. Dr. Nelson Leon Meldonian, grande profissional e um excelente amigo, a quem os meus agradecimentos são infinitos diante de todo carinho, apoio, confiança durante todos esses anos.

Ao Prof. Dr. Tufic Madi Filho, pela participação na Comissão Julgadora do exame de capacidade e seus comentários críticos ao plano de trabalho.

Aos demais amigos, familiares, professores e todos aqueles que cruzaram em minha vida, participando de alguma forma, direta ou indiretamente, na construção e realização deste trabalho, meus sinceros agradecimentos. 
"Que os vossos esforços desafiem as impossibilidades, lembrai-vos de que as grandes coisas do homem foram conquistadas do que parecia impossível."

Charles Chaplin 


\title{
A FLEXIBILIZAÇÃO DA COMPETÊNCIA E DO PROCESSO NORMATIVO EM RELAÇÃO À SEGURANÇA E A PROTEÇÃO RADIOLÓGICA
}

\author{
Vanessa da Ana
}

\section{RESUMO}

O uso e a aplicação cada vez mais constante da tecnologia nuclear consistente em áreas relacionadas à saúde, energia, industrial, bélica, agrícola, entre outras, faz com que haja a necessidade de uma regulamentação de acordo com os padrões de segurança e proteção radiológica internacionais. Dessa forma, utilizando-se de conceitos provenientes do Direito Constitucional, do Direito Ambiental e do Direito do Trabalho, o enfoque da presente pesquisa foi investigar a difícil questão da competência nuclear e a competência ambiental, a impossibilidade de legislar dos Estados, bem como a falta de regulamentação sobre Rejeitos radioativos. Para tanto, foram atualizados e revisados critérios e métodos de interpretação constitucional para solucionar possíveis antinomias jurídicas advindas de múltipla positivação de normas pelos entes federados que dificultam tanto $\circ$ asseguramento quanto 0 aprimoramento da Proteção radiológica do trabalhador e do meio ambiente. Finalmente, a hipótese considerada demonstrou que as mudanças na estrutura legislativa nas três esferas de poderes são necessárias, visando à aplicabilidade de responsabilidade legal na esfera nuclear, principalmente no que se refere às entidades administrativas e estatais. 


\title{
THE FLEXIBILITY OF COMPETENCE AND REGULATORY PROCESS REGARDING SAFETY AND RADIATION PROTECTION
}

\section{Vanessa da Ana}

\begin{abstract}
The use and increasingly steady application of consistent nuclear technology in areas related to health, energy, industrial, war, agriculture, among others, means that there is a need for regulation in accordance with the safety standards and international radiological protection. Thus, using concepts from the Constitutional Law, Environmental Law and Labor Law, the focus of this research was to investigate the difficult issue of nuclear competence and environmental responsibility, the impossibility of legislating states, as well as the lack of regulation on radioactive waste. Therefore, it has been updated and revised criteria and methods of constitutional interpretation to solve possible legal antinomies arising from multiple positivation of the federal entities rules that hinder both the assurance and the improvement of radiation protection of workers and the environment. Finally, the working hypothesis has shown that changes in the legislative framework in the three spheres of power is needed in order to applicability of legal liability in the nuclear sphere, especially with regard to administrative and state entities
\end{abstract}




\section{SUMÁRIO}

Página

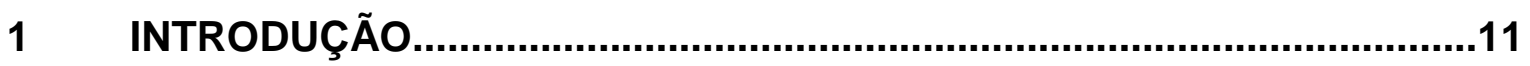

2 FINALIDADE, OBJETIVOS E JUSTIFICATIVA.....................................13

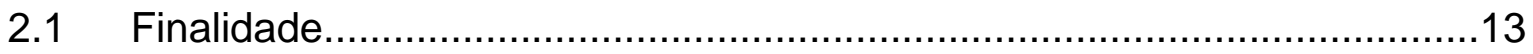

2.2 Objetivos

2.3 Justificativa

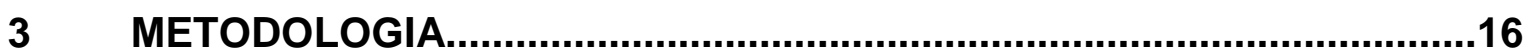

4 NOÇÕES HISTÓRICAS DO SURGIMENTO DO PARLAMENTO...............19

4.1 Conceito e contexto histórico da proteção e segurança radiológica no Brasil

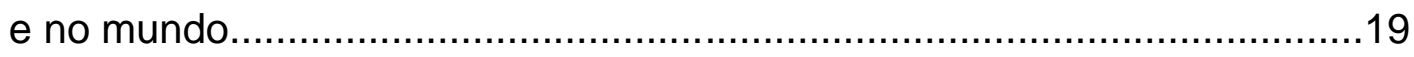

4.2.1 Processo Normativo: principais aspectos estruturais, históricos e de funcionamento no sistema romano germânico e na aplicação em alguns

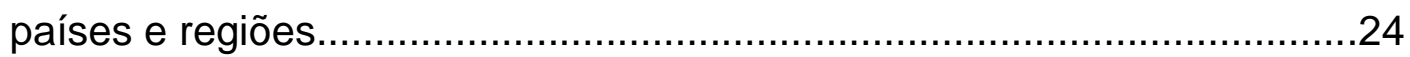

4.2.2 Revolução Liberal de 1688 e a monarquia constitucional...........................28

4.2.3 Revolução Francesa e a Constituição da Assembleia Legislativa...............31

4.2.4 O modelo de parlamento Norte-Americano: função do Senado....................32

4.3 O Parlamento e a América Latina.............................................................

4.4 Poder Legislativo no sistema Brasileiro: aspectos gerais e históricos.........35

4.3.1 Formação histórica: a Constituição de 1824, a Constituição de 1891 e o

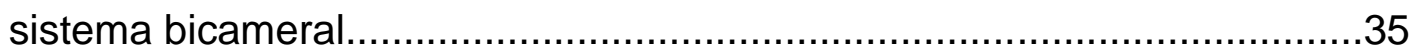

4.3.2 O Legislativo na Constituição de 1934 e o bicameralismo de 1937.............39

4.3.3 A redemocratização de 1946 e a atividade legislativa................................40

4.3.4 O regime militar: novo modelo de funcionalismo do Congresso .................42

4.3.5 A Constituição de 1988 e a participação social...........................................44 
5 DIREITO NUCLEAR BRASILEITO: COMPETÊNCIA LEGISLATIVA .46

5.1 Elementos do processo legislativo e o processo de formação das leis......46

5.1.1 Definição e principais modalidades de norma.......................................47

5.1.2 A lógica e o funcionamento do processo de formação legislativa...............50

5.1.3 As comissões parlamentares no processo legislativo brasileiro.................52

5.2 A Competência legislativa no Direito Nuclear Brasileiro............................53

5.2.1 A competência legislativa e privativa da União.......................................56

5.2.2 A competência legislativa dos Estados e do Distrito Federal....................60

5.2.3 A competência legislativa e privativa dos Municípios...............................65

5.2.4 Competência legislativa concorrente dos entes federados: aspectos

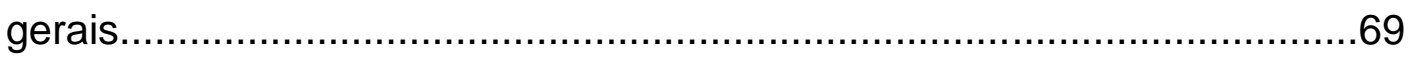

5 Competências administrativas comuns a todos os entes federados..........73

6 DESENVOLVIMENTO DO TRABALHO................................................76

6.1 Competência materiais ou legislativas decorrentes no Direito Nuclear......76

6.2 Competência em relação aos rejeitos radioativos e a responsabilidade civil.

6.3 Interpretação constitucional e sua flexibilidade: na busca de celeridade e da regulamentação do Direito nuclear.................................................81

6.3.1 Multiplicidade de centros normativos................................................... 83

6.3.2 Antinomias e a taxonomia na análise dos conflitos................................84

6.3.3 Tratados internacionais: celeridade na solução de conflitos e maior regulamentação na segurança e proteção radiológica..............................87

7 RESULTADOS E DISCUSSÃO..........................................................89

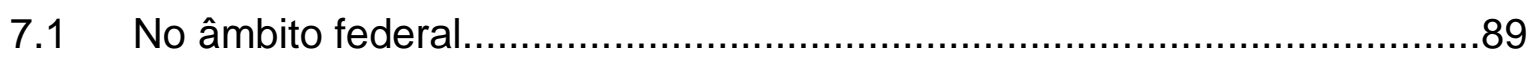

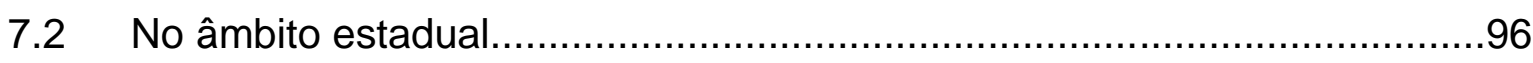

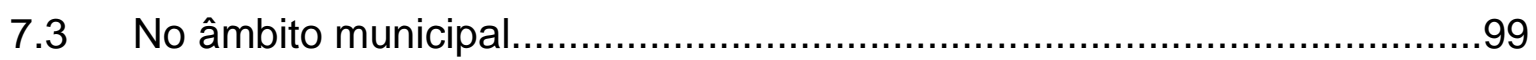

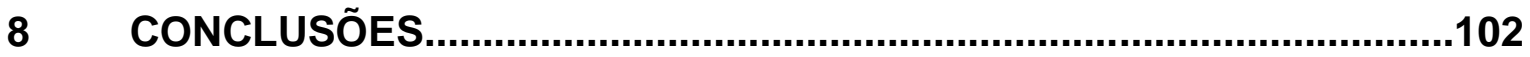

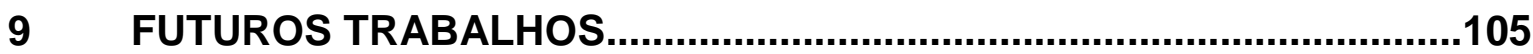

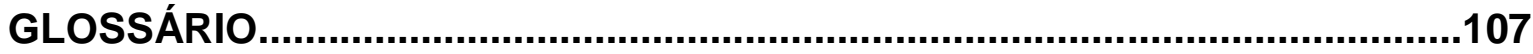

REFERÊNCIAS BIBLIOGRÁFICAS.............................................................117 


\section{LISTA DE ABREVIATURAS E/OU SIGLAS}

CF/88 Constituição da República Federativa do Brasil de 1988, também conhecida como Carta Magna ou Constituição de 1988.

CNEN Comissão Nacional de Energia nuclear.

EC Emenda Constitucional

IAEA International Atomic Energy Agency.

ICRP International Commission on Radiological Protection.

LC Lei Complementar.

MCT Ministério da Ciência e Tecnologia.

OEIA Organismo Internacional de Energia Atômica.

ONU Organização das Nações Unidas.

SIPRON Sistema de Proteção ao Programa Nuclear Brasileiro

UNSCEAR United Nations Scientific Committee on the Effects of Atomic Radiation 


\section{INTRODUÇÃO}

Com o passar dos tempos o homem cada vez mais vem se tornando dependente das fontes de energia, não apenas da energia proveniente dos alimentos que gera seu sustento, mais também de todas aquelas que por ventura vem ser utilizadas por ele, melhorando cada vez mais o ambiente e a qualidade de vida em que vive.

Exemplo disso é a utilização crescente da energia nuclear, considerada como umas das principais fontes de energia mais limpas para o meio ambiente e benéfica ao homem. Tornou-se, então, mais uma opção, capaz de atender a demanda energética do mundo moderno com eficácia e especialmente Segurança'.

Contudo, alguns estudos demonstram que o consumo de energia tende a se estabilizar ou crescer em menor escala a medida que o país se desenvolve, porém nos países em desenvolvimento que é o caso do Brasil, a demanda de energia está em extraordinário crescimento, o que preocupa as dimensões das ações governamentais a serem tomadas, principalmente no que se refere a sua regulamentação, proteção e utilização ${ }^{2}$.

Para se obter uma melhor ideia deste crescimento, desde a utilização da energia nuclear no $\mathrm{Brasil}^{3}$, em meados da década de 1930, momento em que a possível utilização do potencial energético dos minérios radioativos instigava a indústria bélica em todo o mundo, até 2012 já houve inúmeros investimentos financeiros e incentivos na excelência científico-tecnológica na busca do melhor desenvolvimento sócio econômico nacional sustentável. Como exemplo disso, é a retomada do Programa Nuclear Brasileiro em 2002 pelo governo que mantém em sua Política Nacional a aplicação dos materiais nucleares estritamente voltados para a paz, conforme firmado pelo Brasil desde o ano de 1984 na Assembleia Geral da ONU como signatário da "Declaração sobre o Direito dos Povos à Paz"4 . 
No que se refere à regulamentação deste crescimento na demanda de Energia nuclear é importante ressaltar que, desde a promulgação da primeira Lei ordinária que criou o monopólio dos minerais nucleares submetidos à união em 1950, foi somente com a Constituição da República Federativa do Brasil de $1988^{5}$, ainda vigente em todo território nacional, que dispôs, expressamente, mas maneira superficial, sobre a responsabilidade civil pelos danos decorrentes da utilização de material nuclear e mais, em seu art. 225 determinou que a localização das usinas que se utilizasse de material radioativo em sua Instalação deveria ser definida por competência de Lei Federal, após autorização dos estados e municípios.

Dessa forma, com base na revisão de literatura, nota-se que foi traçado, de forma genérica, toda a estrutura de Direito Nuclear na atualidade baseada em uma repartição legiferante positivada pelo constituinte, decorrente do modelo de Estado que adotou o federalismo de equilíbrio.

No entanto, observa-se que embora a União tenha competência legislativa privativa frente ao seu papel institucional de coesão nacional sobre assuntos nucleares e radioativos, os Estados-membros, o Distrito Federal e os municípios ${ }^{6}$ possuem grande importância na aplicação da estrutura do Direito Nuclear, principalmente no que se refere à tecnologia empregada, ao meio ambiente, a Proteção às radiações ionizantes e Rejeitos radioativos e, ainda, suas consequências sociais e jurídicas. 


\section{FINALIDADE, OBJETIVOS E JUSTIFICATIVA}

\subsection{Finalidade}

O presente trabalho estuda a repartição da competência positivada pelo constituinte, decorrente do modelo de Estado encampado pela Carta Magna de 1988, que adotou o federalismo de equilíbrio ${ }^{7}$. Em contrapartida, também se estuda o desenvolvimento do processo normativo em relação à Proteção radiológica e a Segurança quando aplicado nas áreas de energia, indústria, saúde, meio ambiente, agricultura e recursos hídricos ${ }^{8}$. O estudo busca aclarar critérios e métodos de interpretação constitucional para solucionar possíveis antinomias jurídicas advindas de múltipla positivação de normas pelos entes federados que dificultam tanto o asseguramento quanto o aprimoramento da Proteção radiológica do trabalhador e do meio ambiente ${ }^{9}$.

\subsection{Objetivos}

O trabalho inicia-se com o exame dos conceitos essenciais do Direito Nuclear, bem como um breve contexto histórico da segurança e proteção radiológica no Brasil, com o intuito de esclarecer as principais peculiaridades sobre o tema.

Em seguida, parte-se para a análise da clássica teoria da separação de Poderes $^{10}$ levando-se em consideração que, dentre as três instituições do Estado, é o Poder Legislativo que tem a sua história de criação relacionada com as mudanças sociais que culminaram com a criação de novos direitos, garantias e a reformulação do próprio Poder Público ${ }^{11}$. Diante desse poder de controlar os atos reais a partir da elaboração de normas jurídicas é que o Poder legislativo 
adquiriu maior notoriedade à medida que se tornou o poder de representação da vontade social e cientifica.

Já a terceira parte do trabalho dedica-se à temática da divisão de competências legislativas entre os entes federados, sua concepção, suas características e sua evolução ${ }^{12}$. Aborda, assim, a trajetória do federalismo brasileiro, as peculiaridades da distribuição de competências conforme os critérios de ótica horizontal e vertical, as outras formas de cooperação administrativa, a divisão de forças políticas entre os entes federados e as críticas daí decorrentes ${ }^{13}$.

O estudo então se foca na competência legislativa privativa dos entes federados, inicialmente pela União ${ }^{14}$ frente ao seu papel institucional de coesão nacional sobre assuntos nucleares e radioativos. A posteriori, analisar-se-á a competência legislativa dos Estados-membros e do Distrito Federal na busca de competência legislativa remanescente no concerto da federação ${ }^{15}$ e das diretrizes da Constituição da República Federativa do Brasil de 1988 na formatação da autonomia dos entes federados. Além disso, o estudo voltar-se à competência legislativa municipal, sob a perquirição do interesse municipal para batizar a legitimidade da Lei municipal no concerto com as demais ${ }^{16}$.

A discussão é enriquecida com as implicações legislativas do sistema de cooperação entre os entes federados no regime da região metropolitana e a execução de funções públicas de interesse comum ${ }^{17}$.

Por fim, discute-se à temática da interpretação jurídico-constitucional das competências legislativas a partir da leitura dos métodos da neohermenêutica constitucional, baseada no contexto fático, valorativo e principiológico ${ }^{18}$ que 0 intérprete ${ }^{19}$ depara na análise das possíveis antinomias que os multicentros normativos podem originar.

Fiel às origens do federalismo e a sua interpretação, sugere-se soluções hermenêuticas ${ }^{20}$ e principiológicas para a maior atualização e flexibilização da legislação brasileira no setor nuclear; as críticas aos preceitos normativos que geram insegurança e multiplicação desorganizada de diplomas legais esparsos e a consequente repercussão política na conjugação dessas forças ${ }^{21}$, com o intuito de proporcionar o fortalecimento da comunicação e interação da equipe gerencial e executiva da tecnologia nuclear. 
O trabalho procura trazer exemplos marcantes colhidos da jurisprudência nacional e do Direito Comparado ${ }^{22}$, bem como as possíveis interações dos Tratados Internacionais do Direito Nuclear no ordenamento jurídico brasileiro, ${ }^{23}$ como forma de ilustrar possíveis conflitos de leis entre os entes federados, seja entre leis federais versus estaduais ou sua recíproca ${ }^{24}$ e a interação das municipais ${ }^{25}$, quando 0 assunto é proteção e segurança radiológica ${ }^{26}$.

Neste contexto, o tema do presente trabalho é realmente importante, apresentando contribuição à área do conhecimento.

\subsection{Justificativa}

Há uma grande necessidade de assegurar a proteção e segurança radiológica nos setores que envolvem aplicação nuclear, como por exemplo, na energia, na industrial, na saúde, no meio ambiente, entre outros. Para isso é necessário a atualização e a flexibilização da legislação brasileira tanto no aspecto da aplicação aos entes federativos quanto no processo normativo de futuras leis regulamentadoras.

Neste contexto, o tema da presente pesquisa é realmente importante, apresentando contribuição à área científica e social do conhecimento. 


\section{METODOLOGIA}

A presente pesquisa classifica-se quanto aos fins em exploratória e aos meios em bibliográfica, analise de normas e documentos reguladores da Proteção radiológica no Brasil.

$\mathrm{Na}$ elaboração da pesquisa bibliográfica e documental foram utilizadas bases de dados nacionais de assuntos que estão publicados em livros, artigos de revistas, eventos e teses, a saber: INIS - Internacional Nuclear Information System, Biblioteca digital brasileira de teses e dissertações, Biblioteca do Senado Federal, Biblioteca Brasileira de Direito, Biblioteca Digital de Teses e Dissertações da Universidade de São Paulo, entre outros.

No que se refere ao processo normativo foi efetuado uma analise da Constituição da República Federativa do Brasil de 1988 e de um consolidado da legislação brasileira aplicada ao setor nuclear, através de visitas monitoradas às Casas Legislativas do Brasil, quais sejam: Câmara dos Deputados e o Senado Federal.

$\mathrm{Na}$ segunda parte da pesquisa-científica foi realizada uma análise bibliográfica da clássica teoria da separação de Poderes, mantendo-se o enfoque dogmático e dedutivo.

Foram utilizadas as bases de dados nacionais como: Biblioteca digital brasileira de teses e dissertações, Biblioteca do Senado Federal, Biblioteca Brasileira de Direito, Biblioteca Digital de Teses e Dissertações da Universidade de São Paulo, Banco de teses da Coordenação de Aperfeiçoamento de Pessoal de Nível Superior, entre outras.

Já a terceira parte do trabalho dedicou-se à temática da divisão de competências legislativas entre os entes federados. Nesta etapa foi mantido o enfoque dogmático e dedutivo, sendo utilizadas as bases de dados nacionais 
como: Biblioteca digital brasileira de teses e dissertações, Biblioteca do Senado Federal, Biblioteca Brasileira de Direito, Biblioteca Digital de Teses e Dissertações da Universidade de São Paulo.

Considera-se que estas primeiras três partes desenvolvidas nos capítulos 4 e 5 constituem o conhecimento profundo sobre o tema proposto a ser desenvolvido na pesquisa e estão descritos nos capítulos 6, 7 e 8 deste trabalho de dissertação.

Em seguida, quando o foco da pesquisa foi a analise da competência legislativa privativa dos entes federados em relação a assuntos nucleares $\mathrm{e}$ radioativos, foi efetuada a analise da Constituição da República Federativa do Brasil de 1988 e de documentos consultados através de visitas monitoradas às Casas Legislativas do Brasil.

Por fim, foi realizada uma leitura dos métodos da neo-hermenêutica constitucional, baseada no contexto fático, valorativo e principiológico das principais Doutrinas e Jurisprudências sobre Direito Constitucional Comparado e Direito Nuclear.

Dessa forma, para atingir os objetivos do presente trabalho, foi utilizada ampla pesquisa bibliográfica e documental baseadas em dados referenciais e internacionais de assuntos que foram publicados em livros, artigos de revista, eventos e teses, como: INIS - Internacional Nuclear Information System, Nuclear Power; Nuclear Fuel Cycle \& Waste Technology, Planning \& Economic Studies Section, Energy Technology Data Exchange, Biblioteca digital brasileira de teses e dissertações, Biblioteca do Senado Federal, Biblioteca Brasileira de Direito, Biblioteca Digital de Teses e Dissertações da Universidade de São Paulo, Banco de teses da Coordenação de Aperfeiçoamento de Pessoal de Nível Superior, entre outras.

O desenvolvimento do presente trabalho foi realizado nas dependências tanto do Instituto de Pesquisas Energéticas e Nucleares bem como da Faculdade de Direito da Universidade de São Paulo, para que, de posse de todo o arcabouço técnico-cientifico e legislativo internacional, nacional, estadual e municipal, cumpra-se todos os objetivos já expostos.

É relevante ainda afirmar que em toda a pesquisa bibliográfica foi também utilizado o sistema eletrônico internet, por meio de sites de buscas como - Google, por meio de um microcomputador de propriedade da autora do 
presente trabalho científico, marca Dell, modelo Inspiron14, série 300 e IP №. 143442-B10. 


\section{NOÇÕES HISTÓRICAS DO SURGIMENTO DO PARLAMENTO}

\subsection{Conceito e contexto histórico da Proteção e Segurança radiológica no Brasil e no mundo}

Inicialmente é importante conceituar os institutos encarregados da proteção e da segurança radiológica no Brasil. Elas podem ser definidas como o conjunto de medidas que visam proteger o ser humano contra possíveis efeitos indesejáveis causados pela radiação ionizante' ou ainda como um padrão apropriado de proteção para o homem, sem limitar os inegáveis benefícios das aplicações destas radiações.

A proteção radiológica, também conhecida como radioproteção, visa a segurança em situações normais de trabalho na Instalação enquanto que a segurança visa a proteção em situações anormais de trabalho, isto é, nas situações indesejáveis que fogem a normalidade. Considera-se situação normal de trabalho aquela que ocorre normalmente conforme planejado, mas engloba pequenas situações anormais com probabilidades anuais iguais ou superiores a $1 \%$ (um por cento). Para as situações normais de trabalho deve (obrigatório) aplicar-se o sistema de limitação de dose.

As situações anormais de trabalho englobam o que se convencionou determinar de exposição potencial, ela engloba as situações de trabalho indesejáveis, mas que podem ocorrer com probabilidades anuais inferiores a 1\% (um por cento) e com doses somente previsíveis sem nenhuma certeza que elas

\footnotetext{
' A radiação ionizante consiste em ondas eletromagnéticas ou de partículas com energia suficiente para fazer com que os elétrons se desprendam de átomos e moléculas, alterando sua estrutura num processo conhecido como ionização. Como resultado, eles tornam-se eletricamente carregados. As principais radiações particuladas em uso são a radiação beta, isto é, elétrons negativos e positivos; prótons, radiação alfa constituída de um núcleo de hélio e nêutrons.
} 
devam ocorrer. Neste caso, as doses previstas são superiores àquelas prognosticadas no sistema de limitação de doses.

Atividades que tenham probabilidades superiores a 1\% (um por cento) ao ano com situações anormais previsíveis que apresentam doses superiores às preconizadas pelo sistema de limitação de doses são proibidas. As exposições potenciais podem envolver tanto incidentes como acidentes.

Considera-se como incidente se a exposição potencial permanece limitada à propriedade da instalação radiativa ou nuclear e como acidente aquela que envolve o público externo à propriedade da instalação.

Agora examinar-se-á o porquê em proteção radiológica faz-se esta diferença entre proteção e segurança.

Em situações normais de trabalho, que é quando se aplica a denominação de proteção, ela é realizada de três maneiras diferentes, a saber:

a) Proteção a fonte, isto é, protege-se a fonte por meio da blindagem.

b) Proteção ao indivíduo, interpondo-se meios blindantes entre a fonte de radiação e o indivíduo.

c) Proteção ao meio ambiente entre a fonte de radiação e o indivíduo. Esta proteção é realizada modificando ou suprimindo vias de percurso da radiação que alcança o indivíduo.

A segurança, conforme já mencionado, relaciona-se com a exposição potencial e ela é realizada com o que se convencionou denomina-la em proteção em profundidade, que é realizada por barreiras em várias distâncias. Por exemplo, o reator IEA-R1 do IPEN tem como primeira barreira em profundidade a piscina, como segunda barreira, as paredes de concreto e aço da piscina, como terceira barreira as paredes do prédio do reator, como quarta barreira a portaria que cerca o prédio do reator e o bloco 00 e por último, como quinta barreira a portaria geral do IPEN.

A radioproteção compreende 0 estudo das características das radiações ionizantes, isto é, nas situações indesejáveis que fogem a normalidade; da constituição da matéria; da interação da radiação ionizante com a matéria; da célula; dos efeitos biológicos associados ao ser vivo; das formas de proteção, incluindo a blindagem à radiação e da legislação aplicada à área.

Ressalva-se que as radiações ionizantes não são percebidas naturalmente pelo homem por meio de seus órgãos e sentidos, como ocorre, por 
exemplo, com a luz e com o calor. Talvez seja por isso que a humanidade não conhecia a existência da radioatividade e nem seu poder de dano e benefícios até os últimos anos do século XIX, embora fizessem parte do meio ambiente.

Em 1895, Wilhelm Conrad Roentgen, pesquisador alemão, descobriu os raios $\mathrm{X}$ bem como suas propriedades, o que despertou grande interesse principalmente da classe médica", pois, em 1896, já foi instalada a primeira unidade de radiografia diagnóstica nos Estados Unidos.

Também em 1896, Antoine Henri Becquerel, físico francês, demonstrou que $O$ sal de urânio com que ele fazia seus experimentos emitia radiações espontaneamente semelhantes às dos raios $X$.

As pesquisas e as descobertas sucederam-se anos seguintes e o casal Pierre e Marie Curie foram responsáveis pela descoberta e isolamento dos elementos químicos naturalmente radioativos como o polônio e o rádio.

A posteriori, estudos, experimentos e conhecimentos obtidos por muitos pesquisadores e cientistas como Ernest Rutherford, Niels Bohr, Max Planck, Louis de Broglie, Albert Einstein, Enrico Fermi, entre outros, sobre a constituição da matéria e dos átomos foram sendo elucidados, o que resultou na descoberta da radioatividade e de suas interações com a matéria, contribuindo, dessa forma, para o desenvolvimento da física atômica, nuclear e de partículas, mecânica quântica e ondulatória.

Em 1939, já se tinha o conhecimento de que o átomo podia ser rompido e que uma grande quantidade de energia seria liberada na ruptura, ou seja, na fissão do átomo. Essa energia foi designada como "energia atômica" e mais tarde como "Energia nuclear". Esses conhecimentos científicos possibilitaram a construção de reatores nucleares e explosivos nucleares.

No final da década de 30 e início da década de 40, a busca pela hegemonia nuclear fez com que muitos países que estavam envolvidos na Segunda Guerra Mundial, investissem na construção da bomba atômica e em seu

"Os raios $X$ atravessavam o corpo humano, provocavam fluorescência em determinadas substâncias e impressionavam chapas fotográficas. Eles permitiam obter imagens do interior do corpo. 
poder destruidor perante a humanidade, como ocorreu em meados de 1945, com bombas atômicas lançadas nas cidades de Hiroshima e Nagasaki'l'.

Após o período da Grande Guerra, houve a preocupação em se aplicar a energia nuclear em benefício da humanidade, como por exemplo, na construção de usinas elétricas e na aplicação de materiais radioativos para melhorar as condições de vida da população, principalmente, nas áreas da saúde, industriais e do meio ambiente.

É importante destacar que a história do desenvolvimento da energia nuclear também foi acompanhada por outros acontecimentos desagradáveis, além das explosões nas cidades de Hiroshima e de Nagasaki. Esses acontecimentos ocorreram quando não se tinha ainda o entendimento adequado sobre os efeitos biológicos das radiações ionizantes, como foi o caso, por exemplo, das operárias que trabalhavam pintando painéis e ponteiros luminosos de relógio em New Jersey, entre os anos de 1917 e 1924, e, após apresentarem lesões nos ossos, muitas delas acabaram sendo levadas a óbito. Destarte que, as referidas lesões foram provocadas pelas radiações emitidas pelos sais de rádio, ingeridos pelas operárias, durante o seu trabalho.

Estes fatos despertaram a atenção da comunidade científica fazendo com que fosse criado um novo ramo da ciência, denominado de proteção radiológica. Sua principal finalidade é, até os dias atuais, de proteger os indivíduos e seu meio ambiente, regulamentando e limitando o uso das radiações em condições aceitáveis.

No 2으 (segundo) Congresso Internacional de Radiologia realizado em Estocolmo, em 1928, foi fundada a Comissão Internacional de proteção Radiológica (CIPR), também conhecida em inglês como International Commission on Radiological Protection (ICRP), formada por peritos em proteção radiológica em que se recomendam limites de dose e outros procedimentos de trabalho seguro com radiações ionizantes. Esta comissão, ainda continua como um órgão científico que elabora recomendações sobre a utilização segura de materiais radioativos e de radiações ionizantes ${ }^{\mathrm{IV}}$.

\footnotetext{
III O efeito das bombas não se restringiu à explosão propriamente dita e ao calor gerado por ela, mas também muitas pessoas atingidas morreram posteriormente pelos efeitos causados pelas radiações ionizantes.

IV A CIPR a partir daquela data publicou suas recomendações em revistas internacionais de radiologia. Com o programa de átomos para a paz, estabelecido em 1955, a CIPR resolveu
} 
Outros grupos foram criados posteriormente, com o objetivo de aprofundar os estudos neste campo, como é o caso, por exemplo, do Comitê Científico sobre os Efeitos das Radiações Atômicas das Nações Unidas (CCERANU), também conhecido, em inglês como, United Nations Scientific Committee on the Effects of Atomic Radiation (UNSCEAR) criada pela Assembléia Geral da Organização das Nações Unidas em 1955 e o Organismo Internacional de Energia Atômica (OIEA), também conhecido, em inglês como International Atomic Energy Agency (IAEA), fundada em 1957, em Viena, como órgão oficial da Organização das Nações Unidas.

O OIEA promove a utilização pacífica da energia nuclear pelos países membros e tem publicado padrões de segurança e normas para manuseio seguro de materiais radioativos, transporte e monitoramento ambiental.

O OIEA formalizou um contrato com a CIPR de que para as recomendações internacionais de radioproteção, adotaria na íntegra a filosofia de proteção e segurança da CIPR, ainda que editasse suas próprias publicações. Neste caso, enquanto a CIPR em suas publicações justifica as recomendações, o OIEA não o faz, mas é mais detalhista nelas.

A Academia de Ciências dos Estados Unidos também criou um órgão com prerrogativas análogas ao CCERANU denominado: "Biological Effect of lonizing Radiation", isto é, Efeitos Biológicos das Radiações lonizantes.

No Brasil, a utilização das radiações ionizantes e dos materiais radioativos e nucleares é regulamentada pela Comissão Nacional de Energia nuclear $(C N E N)^{\vee}$. Para trabalhar com radiações ionizantes e com materiais

realizar suas próprias publicações em forma de relatório. A primeira publicação da CIPR foi emitida em setembro de 1958. Recomendações subsequentes foram publicadas em 1964, em 1966 e em 1977. A Publicação 26, de 1977, ampliada em 1978, foi aprimorada nos anos de 1980 e 1987. As recomendações foram completamente revisadas e publicadas em 1991 como Publicação 60 e, por fim, em 2007, com a Publicação 103.

As publicações da CIPR têm como objetivo ajudar tanto os responsáveis pela proteção radiológica quanto os indivíduos, como por exemplo, os radiologistas, na tomada de decisões sobre proteção no uso de radiação ionizante.

O estabelecimento de um padrão apropriado de proteção, considerando a melhor relação entre custos e benefícios, não pode ser obtido apenas com base em conceitos científicos, mas deve considerar todos os diferentes tipos de riscos de importância significativa e fazer um balanço entre os riscos e os benefícios associados.

V A CNEN, criada em 1956, como uma unidade do Ministério da Ciência e Tecnologia (MCT), é responsável pela segurança no uso da energia nuclear em território nacional. É referência nas áreas de radioproteção e enriquecimento de urânio e responsável pela publicação das normas que regulamentam a utilização da radiação ionizante no Brasil.

A norma de radioproteção, CNEN - NN 3.01, estabelece os princípios básicos de radioproteção, os limites de dose e as grandezas utilizadas em radioproteção. 
radioativos, são necessários conhecimento e responsabilidade, conforme a legislação pátria brasileira.

\subsection{Processo Normativo: principais aspectos estruturais, históricos e de funcionamento no sistema romano germânico e na aplicação em alguns países e regiões}

Inicialmente é importante observar que abordar acerca do processo normativo é o mesmo que analisar a criação das normas, leis, ou seja, falar do processo que ocasiona a criação das regras de conduta da sociedade. Em suma, é observar como as leis são feitas ${ }^{\mathrm{V}}$.

\section{Segundo Norberto Bobbio:}

A normatividade é a simples previsão das normas de condutas sociais, positivas ou negativas, em determinados tipos legais, sejam civis ou penais. É o poder político, através da função legislativa, direcionando positiva (comando) ou negativamente (proibindo) os comportamentos dos membros da comunidade para os fins preestabelecidos ${ }^{25}$.

Assim, se falar em processo normativo é também falar em elaboração de normas ${ }^{\mathrm{VII}}$, deve-se, também, observar o que vem a ser processo legislativo ${ }^{\mathrm{VIII}}$, qual a sua origem e principais aspectos, uma vez que o mesmo também compreende a elaboração de leis ${ }^{\mathrm{X}}$.

No que se refere ao sistema romano-germânico, que, em oposição ao fenômeno tipicamente inglês da common law $^{X}$ (sistema jurídico baseado na

\footnotetext{
V'É importante observar que norma pode ser entendida em dois aspectos: da proteção radiológica e o jurídico. No que se refere ao aspecto da proteção radiológica, as normas são recomendações sem caráter obrigatório e vinculante. Prevalece 0 interesse e o consenso das partes. Já os regulamentos são obrigatórios a todos os agentes.

No âmbito jurídico, normas são regras gerais e permanentes a que todos estão submetidos. São obrigatórias e estabelecidas por Direito. Já os regulamentos são estatuto que prescrevem o que se deve fazer ${ }^{76}$.

VII “(...) Normas jurídicas são padrões de conduta social impostos pelo Estado, para que seja possível a convivência dos homens em sociedade. (...) Em síntese, norma jurídica é a conduta exigida ou modelo imposto de organização social"77.

VIII Processo legislativo pode definir-se como "(...) um conjunto de fases constitucionalmente estabelecidas, pelas quais há de passar o projeto de lei, até sua transformação em lei vigente.." ${ }^{78}$.

IX "Esta é apenas uma das formas de expressão das normas, que se manifestam também pelo Direito Costumeiro e, em alguns países, pela jurisprudência., ${ }^{, 77}$.

${ }^{x}$ Common Law é uma estrutura mais utilizada por países de origem anglo-saxônica como Estados Unidos e Inglaterra. Uma simples diferença é que lá o direito se baseia mais na Jurisprudência
} 
decisões proferidas pelos tribunais), é denominado pelos britânicos de civil law, formou-se na Europa continental, a partir do século XIII d.C., e, ainda hoje, conserva essa região como seu principal centro ${ }^{27}$. Decorre dos princípios e regras dos antigos direitos romano e canônico, os quais, associados aos costumes dos povos germânicos que definitivamente ocuparam a Europa central após o século $V$ d.C., formando, dessa forma, um conjunto elaborado de normas jurídicas que são a base dos ordenamentos dos países influenciados pelas nações do continente europeu, direta ou indiretamente.

Contudo, o sistema romano-germânico se desenvolve em três períodos, são eles:

O primeiro período iniciou se com o renascimento dos estudos de direito romano nas universidades, por volta dos séculos XII e XIII d. C.. Destarte que a necessidade do estudo universitário no direito Romano nem sempre esteve em debate. Ao contrario, durante séculos ele não foi discutido, embora tivesse variado a orientação de seu ensino, que, por vezes, em alguns lugares, chegou a ser proibido ou rejeitado.

Assim, neste primeiro período, a dificuldade que se apresentava era a utilização da pratica do Corpus luris Ciuilis, em que foi necessário o estudo aprofundado dessa compilação, não só para aclarar suas obscuridades, mas também para aproximar as passagens paralelas ou semelhantes, revelando, inclusive, as antinomias, e tentando dar-lhes solução. Esse trabalho só se poderia fazer em centros de estudo e de saber como eram as universidades. Seus artífices foram os glosadores, denominação que thes adveio do uso das glosas aos textos romanos, pelas quais, principalmente, alcançaram o difícil objetivo a que se propuseram. Foram eles que transformaram uma modesta escola de artes existente em Bolonha, no final do século $X$, na Universidade de Bolonha, dedicada precipuamente ao estudo do direito romano, e que, em pouco, adquiriu fama de tal ordem que atraiu grande número de estudantes de outros países, para os quais, em sua volta, traziam os conhecimentos ali adquiridos.

Nos meados do século XIII, Acúrsio ${ }^{28}$ compõe a Magna Glossa, também denominada Glossa Ordinária ou simplesmente Glossa, que nada mais

que no texto da lei. Jurisprudência trata-se do conjunto de interpretações das normas do direito proferidas pelo Poder Judiciário. Ressalva-se que nos países de Common Law também existe a lei, mas o caso é analisado principalmente de acordo com outros semelhantes. 
era a compilação das glosas feitas ao Corpus luris Ciuilis pelos seus antecessores. Essa obra, que é o sintoma da decadência da Escola dos Glosadores, teve larga aceitação, e adquiriu enorme autoridade na pratica jurídica e no ensino do direito, o que estreitou as relações entre a teoria e a prática, dando ensejo ao surgimento de novo método para o estudo do direito romano.

Contudo, é importante ressaltar que os glosadores não levaram em conta a dificuldade da sua aplicação pela vigência de outras fontes jurídicas como o costume, o direito estatutário fundado no Direito germânico e o Direito canônico.

Para vencer essa dificuldade, os pós-glosadores fundaram o segundo período do sistema romano-germânico no século XIV d.C. adotam outra orientação de estudo o mos italicus, por ter sido a Itália onde surgiu e mais se desenvolveu, para dai propagar-se por outros países.

Em forma principalmente de comentários, em que atentavam também para as fontes jurídicas locais e examinavam a casuística, os pós-glosadores se esforçaram em dar organicamente a exegese dos diversos títulos do Corpus luris Ciuilis, procurando extrair deles os princípios e teorias que se ajustassem as necessidades práticas de sua época. Com isso, o direito romano a aplicar-se na pratica não era o que decorre do estudo direto do Corpus luris Ciuilis, mas o que resulta da interpretação da Glossa e da opinião dos comentários dos doutores, cuja autoridade crescia de ponto quando se formava, entre eles, a communis opinio. Dessa atividade criadora dos pós-glosadores resultou um direito romano ajustado às necessidades econômico sociais da vida medieval - o ius commune, destinado, na medida do possível, a substituir os costumes locais, cuja diversidade dava margem a litígios. Sua aplicação não se tinge a Itália, mas se alastra pela Europa culta. Com essa orientação, que visa a finalidades práticas, é o direito romano ensinado nas universidades, do século XIV ao XVI.

No século XVI, em decorrência do renascimento dos estudos clássicos, nova orientação se imprime ao estudo do direito romano pelos juristas que integram o que se denominou Escola Culta. Embora surgida na Itália, é principalmente na França que esse movimento se desenvolve. Nesse país, havia a ideia de que o direito romano introduzir-se-á, por atuação dos legistas dos séculos XIII e XIV, não como ius scriptum, mas, em decorrência de suas qualidades intrínsecas, como ratio scripta, a facilitar a compreensão do direito nacional e a integra-lo, suprindo suas lacunas. Dai a aceitação dessa nova 
Escola, que deixa de lado a interpretação da Glosa e o método dos comentaristas, e se dedica ao estudo das fontes romanas, com o auxílio da filologia e da historia. Inicia-se, assim, o estudo histórico do direito romano, com a investigação e a analise das modificações que seus institutos jurídicos sofreram ao longo de sua evolução.

Em oposição à orientação italiana, o mos italicus surge, como vertente do humanismo, o mos gallicus. Embora essa nova orientação não se tenha adstringido a França, pois floresceu, também, na Alemanha, na Bélgica, na Espanha e até na Itália, o certo é que, mesmo na França, o mos gallicus não conseguiu desbancar o mos italicus, que continuou a ser seguido em centros importantes, como Toulouse.

$\mathrm{Na}$ Itália, onde o surto humanista se havia iniciado, o ensino universitário do direito romano continua a observar o mos italicus. Na Alemanha, o mos gallicus, seguido pelos muitos professores franceses que ensinavam em suas universidades, não chegou, porem, a predominar. A Escola Culta, nas universidades em que dominou, imprimiu caráter cientifico ao estudo do direito romano, pois se dispôs a conhecê-lo pelo simples amor desse conhecimento, sem objetivar qualquer valor pratico, cavando, assim, um lapso entre a teoria e a pratica, acabando por contribuir para o desprestigio do Corpus luris Ciuilis, em virtude das criticas que lhe fez com o descobrimento das interpolações justinianéias.

No século XVII, declina a influência desse movimento, exceto na Holanda, onde mantém seu prestigio, e onde os humanistas não se limitam ao estudo histórico do direito romano, mas tem em vista sua utilização pratica, sem os excessos dos comentaristas. O mos italicus, porém, persiste.

$\mathrm{Na}$ Alemanha, no início dessa centúria, começa a expandir-se o brocardo quidquid non agnoscit glossa nee agnoscit curia, a significar que as partes do Corpus luris Ciuilis que não houvessem sido glosadas, não eram aplicadas pelos tribunais; e, na segunda metade do século, começa a ser usada a expressão usus modemus Pandectarum como denominação do direito comum utilizado pelos alemães.

Para a decadência da escola culta vários fatores conspiraram: o exagero das sutilezas e das minucias especialmente de natureza filológica, em que incidiram muitos de seus adeptos, fez avolumar-se a critica de que eram eles 
antes antiquários do que juristas; o proposito dessa escola de libertar a pratica forense da autoridade da communis opinio doctorum com o estabelecimento, pelo estudo das fontes romanas, de doutrinas jurídicas mais justas e racionais esbarrou com a resistência da própria práxis, que se adaptava melhor ao mos italicus; e a reação que começou a surgir contra a demasiada preferencia que se dava ao direito romano, nas universidades e no foro, em detrimento dos direitos nacionais

No século XVIII, a Escola do direito Natural passa a encarar o direito romano sob nova ótica, dando origem, dessa forma, ao terceiro e último período do sistema romano-germânico, Como, para os jus naturalistas, o que importava era o direito que resultava diretamente da razão direito uno, imutável e eterno, que, portanto, não se formava historicamente, o direito romano só não sofre golpe mais profundo, porque o elemento material de que se serviram os jus naturalistas para revelarem os princípios do direito natural, agia como parâmetro de aferição das normas daqueles que mereciam persistir por se coadunarem com os preceitos da razão natural.

Dessa forma, ambos esses direitos sofreram influência recíproca, o que explica a permanência, no direito privado moderno, de princípios e de institutos jurídicos que de romanos tem apenas a forma, pois sua concepção é jus naturalista.

Daí poder dizer-se que o direito moderno herdou dos jus naturalistas não somente a sistematização do direito privado por eles introduzida, mas também os conceitos que elaboraram e que deu como resultado, no século XIX, a denominada Jurisprudência dos conceitos, estendida a sua aplicação até os dias atuais.

\subsubsection{Revolução Liberal de 1688 e a monarquia constitucional}

A existência do Poder Legislativo, também denominado como Parlamento teve sua origem na Idade Moderna ${ }^{\mathrm{XI}}$, sendo fruto da ascensão do

\footnotetext{
${ }^{\mathrm{X} \mid}$ Ressalta-se que na Idade Antiga já estava presente as breves noções do poder legislativo, contudo, ao analisar-se a existência do Senado Romano, que nasce com o surgimento da República no período de 509 a 27 a.C., observa-se um órgão mais voltado à consulta e as atribuições de governo.
} 
Poder de monarcas considerados não absolutistas e que passaram a compartilhálo com outras classes políticas, que na sua maioria tinham significativo poder econômico, que influíam nas decisões de governo.

Essa transformação ocorre quando, finalmente, o direito válido é aquele respaldado pela lei. O Poder Legislativo acumula não apenas a função de votar a legislação tributária, mas leis gerais, restando ao Monarca um papel de controle e, até mesmo, de freio sobre as ações parlamentares ${ }^{29}$.

Contudo, foi a Revolução Gloriosa de 1688 que traz a efetiva noção de Parlamento que até os dias atuais é conhecida. Jaime II, representante da Dinastia dos Stuarts, era um rei aristocrata que detinha o Poder de um monarca absolutista. Aos seus interesses contrapunham-se os anseios de uma nova classe social, também chamada de burguesia, oriunda do ressurgimento dos centros urbanos após o fim da Idade Média, que passou a ter o Poder econômico, por ser responsável pela geração de riquezas para as nações.

Ademais, a centralização do Poder nas mãos do rei em detrimento do Parlamento tornara-se mais significativa após o fim da commonwealth ${ }^{\mathrm{XI}}$, posterior à deposição de Carlos I por Oliver Crowell, pois a disputa entre o Parlamento e o soberano acirrava-se desde então. Nesse sentido, o rei procurou afastar o Parlamento de suas decisões mais importantes justamente por temer sua sobreposição aos interesses da Coroa.

Ressalta-se que o descontentamento da burguesia com o soberano não se dava apenas por questões econômicas, políticas e religiosas. È cediço que grande parte da riqueza produzida por esta nova classe social acabava convertida no financiamento de luxuosa vida da corte, vivia praticamente à custa dos impostos arrecadados pelo Estado, o que resultou na perda do apoio do Parlamento Inglês, a ponto de, à época ainda incipiente, tramar um golpe com Guilherme de Orange, príncipe da Holanda e genro do soberano. Esse golpe acabou por levar o então príncipe ao Poder.

A função legiferante do Senado Romano pode ser considerada secundária, não sendo de grande importância para a questão do processo de formação das leis.

A Idade Média, tampouco, conheceu este instituto, pois a centralização deste Poder estava nas mãos dos senhores feudais, o que não permitiu o surgimento de outras instituições de caráter abrangente, como por exemplo, a efetiva produção de normas gerais e comportamentais.

xII Commonwealth é uma organização intergovernamental composta por cinquenta e três países membros independentes, através da qual os países com diversas origens sociais, políticas e econômicas são considerados como iguais em status. 
Antes, porém, o novo Rei havia aceitado a estipulação de limites e respeito a direitos, o que foi consagrado com a assinatura da Bill of Rights em $1689^{\mathrm{XIII}}$. Essa Carta fora considerada imprescindível para que o novo monarca tornasse-se o soberano da Inglaterra ${ }^{30}$, pois tal ato reside no fato de que, a partir de então, o Rei governaria sob o império da lei, ou seja, em estado de direito, pondo fim, dessa forma, ao ciclo das monarquias absolutistas que reinavam na Europa.

A posteriori, em 1701, foi selado o Act of Settlement ${ }^{\mathrm{XIV}}$, que tratou de organizar a distribuição do poder entre o monarca e o Parlamento. Com o desenvolvimento do sistema partidário, gerou também uma significativa influência sobre a formação do Estado Norte-Americano após sua independência com a Revolução de 1787.

Destarte que o Parlamento Moderno surge concomitantemente com a ideia de preservação de atribuições da sociedade frente às arbitrariedades do Estado. Assim antes mesmo da revolução Gloriosa de 1688, o Parlamento Inglês já havia conquistado algumas garantias frente ao monarca, como por exemplo, a assinatura da Petition of Rights em 1628 pelo soberano, que permitia àquele poder legislativo controlar os gastos da Coroa. O Habeas Corpuz Act, de 1679, também acabou por limitar o poder do soberano.

Dessa forma, o Parlamento como órgão de controle do poder do Monarca, não apenas para limitar ou controlar seus gastos, mas também como órgão emanado das leis que resguardaram a sociedade. Surgiu com força primeiramente na Inglaterra para, depois, servir de modelo para as Treze Colônias Norte Americanas independentes que tiveram esse órgão para controlar as ações de seus presidentes republicanos bem como para o sistema francês de 1789.

\footnotetext{
XIII Bill of Rights é uma declaração dos Direitos dos cidadãos é uma lista de Direitos considerados importantes ou essenciais a um grupo de pessoas. Com ele, a população tem a liberdade de expressão, a liberdade política e a tolerância religiosa.

xiv Act of Settlement, também conhecido como o Decreto de estabelecimento, foi um decreto do Parlamento da Inglaterra aprovado em 1701 para colocar a sucessão das coroas inglesa e irlandesa na eleitora Sofia de Hanôver e seus herdeiros protestantes.
} 


\subsubsection{Revolução Francesa e a Constituição da Assembleia Legislativa}

Inicialmente é importante ressaltar que a França já tinha notícias das transformações que vinham ocorrendo na Inglaterra. Antes mesmo de eclodir sua revolução, sabia-se da independência das Treze Colônias Norte-Americanas.

Não obstante isso se tem que a corte francesa, ocupante do Palácio de Versalhes, suas dependências e arredores, era considerada uma das mais ociosas de toda a Europa. A dinastia dos Bourbons havia instaurado um estilo de vida peculiar e seguido toda nobreza desde os tempos mais áureos da história moderna da França. Os altos gastos da Coroa e dessa classe social privilegiada, bem como o alto clero, acabava custeado por uma classe não tão bem colocada, mas que pagava seus impostos.

A partir de então, aquela classe oprimida de servos e trabalhadores livres, aliada à nova burguesia que nascia com o ressurgimento das cidades na Idade Moderna, não deu mais trégua as monarquias obsoletas que se legitimavam pela força e com um poder supostamente herdado de Deus. A classe burguesa não podia ser considerada distante do conhecimento intelectual da época, pois sob a influência do iluminismo no campo do direito e da Sociologia Política $^{\mathrm{XV}}$, ela já ocupava funções burocráticas de Estado e influenciava significativamente os rumos do Estado desde o fim da Idade Média.

A revolução francesa nasceu a partir desse choque mundial propiciado pelo pensamento iluminista que em muito se contrapõe com o modelo de Estado que reinava soberanamente sobre a Europa ${ }^{31}$.

A contestação do modelo de Estado vigente, aliado à ciência e ao descontentamento econômico dos mais pobres e da burguesia, propiciou uma transformação na história moderna que ecoou em todos os países, fazendo com que, a Revolução Francesa se tornasse a responsável pela efetiva noção de um Estado constitucional, positivando garantias individuais e obrigando o monarca a

\footnotetext{
${ }^{x V}$ A burguesia já vinha sendo influenciada pelo pensamento do inglês Thomas Hobbes que, em 1651, havia escrito na famosa obra Leviatã. Mais adiante, John Locke, entusiasmado com a ascensão de Guilherme de Orande ao Poder, escreveria, Dois tratados sobre o governo em 1690 e, posteriormente, Charles Louis de Secondante, o Barão de Montesquieu, escreveria na renomada obra, O Espírito da Leis em 1748. Também não há como negar a influência de JeanJaques Rousseau e de sua obra, O Contrato Social, de 1762, que não obstante o influenciado e instigado pensamento iluminista, certamente desagradou àqueles que, à época, estavam no Poder $^{79}$.
} 
jurar a nova declaração de direitos, posteriormente, convertida em uma Constituição de 1791.

A ascensão do terceiro Estado ao Poder, ou melhor, ao comando dos Parlamentos, trouxe à tona essa nova noção de Estado. A partir de então, ainda que se mantivessem os sistemas monárquicos de governos, eles jurariam textos políticos e constitucionais e o Parlamento assumiria um papel fundamental na condução das políticas públicas das nações ${ }^{30}$.

A noção de representação ganhou força e o Parlamento colocou-se como instituição mais adequada para exercê-la em nome da sociedade. Assim, esse órgão tornar-se-ia ainda mais institucionalizado a partir de seu aperfeiçoamento com as repúblicas e com os sistemas presidencialistas que começam a surgir desde então.

\subsubsection{O modelo de parlamento Norte-Americano: função do Senado}

Ao contrário do que ocorrera com a Revolução Francesa, na Revolução que eclodiu em 1787 na América, não se buscava a igualdade de condições e sim na abolição da escravatura, o que poderia ser considerada a maior desigualdade promovida pela colônia pré-independente, e ainda, o fim do nítido sentimento de exploração pela Inglaterra.

Com a gradativa intervenção tributária da Inglaterra sobre os norte americanos, iniciou-se um processo de resistência, uma vez que a interferência na área econômica não agradava à maioria da classe burguesa.

A questão econômica era um ponto de atrito entre a Inglaterra e as Colônias Norte-americanas desde a restauração da Monarquia com Carlos II, pois à época, o Parlamento britânico, tanto na Câmara dos Lordes, quanto na dos Comuns, encontrava-se representado por uma nobreza e uma burguesia ansiosa por retirar da colônia o maior proveito econômico possível. O que houve, então, foi um verdadeiro choque de representatividade que explicitava visões e valores antagônicos para a concepção de Estado.

Destarte que as Colônias Norte-americanas já possuíam assembleias legislativas próprias, aptas para deliberarem sobre assuntos locais. Nesse espaço, o pequeno colono encontrava-se representado e, de alguma forma, já 
possuía certa voz ativa na condução dos negócios em seu locus ${ }^{\mathrm{XV} I}$. Assim, a democracia se tornava conhecida, ou seja, a noção de poder soberano do povo colocava-se como imperativo nessa nova ordem política ${ }^{\mathrm{XVII}}$.

A partir dessa revolução liberal, juntamente com a Revolução Francesa, houve mudança de um sistema político absolutista para um novo modelo de Estado que traz valores tão fundamentais para a sociedade moderna como a soberania, a democracia e a garantia de direitos.

Nessa esteira, e como órgão institucional garantidor de todas essas novas conquistas, o Parlamento ganha uma atribuição fundamental, qual seja, a de positivar o direito em benefício da sociedade.

Tamanha é a importância que essa atribuição adquire nesse novo Estado que, nos Estados unidos, acaba estruturando de forma diferencial, com a criação do modelo parlamentar bicameral. Esse modelo de aperfeiçoamento do Congresso alia-se à noção de um inédito sistema presidencialista, em que o chefe do poder seria escolhido pelo próprio povo em contrapartida ao modelo monárquico que predominava na Europa.

A criação do Senado Federal foi fundamental para a consagração desse novo modelo de Parlamento democrático. Essa segunda Casa cumpria uma função essencial de representação daquelas Colônias, agora federadas em um único Estado, que teriam voz ativa na política estatal ${ }^{32}$.

Assim, ambas as casas tornar-se-iam mais um obstáculo a ser vencido por atos normativos inconvenientes, ou seja, nenhuma lei ou resolução poderia ser aprovada sem o voto favorável da maioria do povo e da maioria dos Estados. Dessa forma, o Presidente da República haveria de fazer cumprir os desígnios traçados pelos representantes populares da Câmara e do Senado Federal.

É de se ressalvar que, com o modelo presidencialista de governo, a criação do Senado acabou por propiciar um novo modelo de Parlamento que seria seguido pelas novas noções emergentes que surgiam a partir de um processo de independência das grandes metrópoles.

\footnotetext{
xv1 Não é atoa que uma das principais características da Declaração de Independência dos Estados Unidos foi a afirmação peremptória desse instrumento como um princípio basilar do novo Estado.

xvII A ideia de soberania popular é, então, cristalizada como instrumento fundamental para o funcionamento do Estado, basicamente, configurou-se como alicerce de um modelo democrático de Estado que passa a se desenhar.
} 
É bem verdade que esse modelo consolidou o sistema bicameral embora não o tenha criado. O Senado americano exerceu um fundamental papel de controle e de revisão das leis aprovadas pela Câmara dos Deputados ${ }^{33}$.

Todavia, esse novo modelo de Parlamento se apresenta como fundamental a partir da convenção da Filadélfia, sendo, inclusive, seguido por importantes nações europeias, como a França e Itália, que, até hoje, mantêm a estrutura senatorial como instrumento de funcionamento de seus respectivos Parlamentos.

\subsubsection{O Parlamento e a América Latina}

Conforme visto anteriormente, os ideais libertários que eclodiram com as revoluções americana e francesa influenciaram, e muito, o processo de libertação das demais colônias na América.

O surgimento do Parlamento como forma de expressão de uma vontade majoritária colocou-se como uma necessidade para esses novos espaços políticos, pois seria através dessa instituição que o liberalismo efetivamente exerceria suas influências sobre essa nova sociedade que se formava.

Tamanha foi a importância da criação do Parlamento que, em um período de setenta anos após as referidas revoluções, ainda que as nações sul americanas vivessem sob a égide de impérios ou de repúblicas embrionárias, essa instituição acabou por ser criada em quase todo os países latinoamericanos.

A Argentina organizou-se em um governo confederativo em 1850. Embora não tenha criado uma Constituição própria em virtude de questões políticas internas, em 1852, foi instituída uma espécie de Legislativo nessa confederação, com participação dos representantes das províncias nos rumos dessa nova estrutura nacional.

Já no Chile, após o processo de independência, instaurou-se um sistema presidencialista centralizado e forte. A participação do Parlamento na elaboração das políticas nacionais somente se efetivou a partir de $1871 \mathrm{com}$ a instituição de um sistema semiparlamentar de governo até então desconhecido nas Américas. 
Todavia, prevalecia no sistema chileno um regime bicameral sendo que a relação entre a Câmara dos Deputados e o Senado Federal não era harmônica, principalmente no período de instabilidade política instaurada no país no final do século XVIII.

História diferente não ocorreu no Paraguai, que se tornou independente da Coroa Espanhola em 1811, data em que se instalou o primeiro Congresso Nacional do País como símbolo da independência.

Portanto, pode-se constatar que os Parlamentos assumiram um papel fundamental na história da consolidação das nações latinas-americanas, sendo possível afirmar que essas nações, ainda que instauradas sob o regime monárquico, tiveram no Parlamento o arrimo necessário para prosperar e se auto afirmarem enquanto Estados independentes e soberanos.

Dessa forma, imprescritível a atuação do Parlamento no fortalecimento da identidade desses novos Estados. A partir de então, essa instituição tornou-se tão essencial quanto a luta pela democracia e pela representação popular.

No que se refere ao Poder Legislativo no Brasil, se estudará mais profundamente no subcapítulo a seguir.

\subsection{Poder Legislativo no sistema Brasileiro: aspectos gerais e históricos}

\subsubsection{Formação história: a Constituição de 1824, a Constituição de 1891 e o sistema bicameral}

Inicialmente é importante observar que o Poder Legislativo no Brasil não tem a mesma origem da instituição Parlamento, como já visto anteriormente, pois desde os tempos do Brasil Colônia, já existia as Câmaras Municipais em todas as vilas. Este órgão era composto por dois juízes ordinários ou do juiz de fora, que serviam um de cada vez. Além disso, faziam parte de sua estrutura três vereadores, um procurador, um tesoureiro e um escrivão que, assim como os juízes e vereadores, eram escolhidos em um processo eleitoral. A Câmara 
nomeava, ainda, os juízes de vintena, almocatés, depositários, quadrilheiros ${ }^{\mathrm{XVIII}} \mathrm{e}$ outros funcionários ${ }^{34}$.

Em verdade, mais do que órgão de deliberação legislativa, a Câmara Municipal representava uma repartição do poder local, uma vez que o sistema de capitanias parecia incapaz dos assuntos comuns de todas as localidades que governava.

Elas surgem mais para permitir uma administração mínima do que para se contrapor ao sistema de administração da Coroa, pois os atos de natureza normativa restringiam-se à elaboração de posturas urbanas ou rurais e editais que sempre eram submetidos ao controle de legalidade do ouvidor, figurara diretamente subordinada ao donatário da Capitania e que exercia sobre os habitantes daquela circunscrição, funções jurisdicionais.

È evidente que aquele modelo de Câmaras Municipais nada tem a ver com a atual estrutura do Poder Legislativo atual, isso porque, conforme se pode constatar, as Câmaras eram uma mistura de Poder judiciário com o próprio legislativo, mas tinham como função básica a administração da justiça local, uma vez que, no período do Brasil Colônia, havia uma tripartição de poderes jurisdicionais.

Somente no inicio do século XIX, em 1822, com a vinda da família real portuguesa ao Estado Nacional após a derrota de Napoleão em Waterloo e a criação do Congresso de Viena em 1815, que se pode afirmar que o Brasil se tornou um país soberano em sua função legislativa.

\begin{abstract}
A 16 de fevereiro de 1822, cedendo à pressão popular, o Rei D. João VI expandiu decreto convocando Procuradores das Cidades e Vilas do Império do Brasil para reunirem-se em "Juntas da Corte" a fim de assentarem as bases constitucionais que atendessem às condições peculiares da América Portuguesa. (...) Por decretos de 7 de março e 22 de abril, o rei determinou que se procedesse à eleição dos Deputados brasileiros. (...) Foram eleitos 72 Deputados pelas províncias do Império do Brasil ${ }^{35}$.
\end{abstract}

\footnotetext{
xVIII Almotacé é o funcionário de confiança dos conselhos na Idade Média (equivalente a um oficial municipal) responsável pela fiscalização de pesos e medidas e da taxação dos preços dos alimentos; sendo encarregado também da regulação da distribuição deles em tempos de maior escassez. Ocupava o cargo da Almotaçaria mensalmente e estava dependente dos governadores do conselho. Já os quadrilheiros eram os agentes de polícia responsáveis pela segurança pública urbana em cada conselho da Coroa Portuguesa, desde a Idade Média até ao início do século XIX. Tinham como missão principal a de prender os malfeitores e entregá-los às autoridades judiciais.
} 
A Assembleia que se desenhou, de cunho bastante liberal, mesmo no plano político, contrapunha-se aos objetivos do Imperador de manter o controle estatal sob seu comando. A principal desavença entre os poderes deu-se em torno das atribuições do Executivo e do Legislativo, como por exemplo, os constituintes exigiam uma contenção do poder imperial para impossibilitar a dissolução da futura Câmara dos Deputados, forçando, assim, novas eleições sempre que o Imperador entendesse conveniente.

Diante desse fato, não foram poucas as vezes que os interesses do Imperador foram antagônicos aos do Parlamento.

Aquele, imbuído de seu poder autoritário e sentindo-se diminuído pelos rumos tomados pela Assembleia, acabou por dissolvê-la em 12 de novembro de 1823 e criou, no dia seguinte, um Conselho de Estado, cuja atribuição principal foi elaborar a nova Constituição, que acabou outorgada em 1824, pelo Chefe de Estado Brasileiro.

Como a Assembleia Constituinte havia sido dissolvida e o Imperador buscava dar uma legitimidade popular ao texto constitucional aprovado, optou-se por submeter o processo às Câmaras Municipais que, sem contestar o poder imperial, e por ter interesse na criação institucional do país, acabaram por ratificar o projeto na íntegra.

Destarte que a estrutura e o processo de escolha dos membros daquele Parlamento podem ser considerados inusitados. A Constituição de 1824 era bastante liberal no que se referia ao processo eleitoral e permitia o voto dos analfabetos e um sistema censitário bastante flexível ${ }^{\mathrm{XIX}}$.

Dessa forma, a Assembleia Geral do Império (que atualmente corresponde ao Congresso Nacional) tonou-se, então, um órgão bastante conservador, a ponto de aprovar, em 1850, um Código Comercial totalmente montado a partir dos interesses do Império e não do Parlamento ${ }^{35}$.

Ação importante para a afirmação do Parlamento deu-se com o Ato Adicional de 1834, quando foi concedida uma parte da autonomia às províncias, em um processo que pode ser considerado de descentralização política, com a

\footnotetext{
${ }^{\mathrm{XIX}}$ A renda exigida para votar era de cem mil-réis ao mês. A maior parte dos trabalhadores ganhava mais de cem mil-réis ao mês. É certo que a inflação colaborou com a inclusão, pois a quantia se desvalorizava. Mesmo assim, a população votante continuou submissa às autoridades locais. As eleições eram violentas e cheias de fraudes. $O$ voto era um ato de obediência.
} 
criação das Assembleias Provinciais, que foram as principais responsáveis pelo desenho institucional do poder local, tal como hoje é conhecido ${ }^{36}$.

Os ideais libertários jamais deixaram de existir, mesmo com o tímido processo de descentralização. A partir de 1870, quando é desencadeado o movimento republicano ${ }^{\mathrm{XX}}$, a noção de federalismo e de autonomia coloca-se novamente como o grande objetivo. Esses movimentos acabaram por derrubar o Segundo Imperador em 1889, quando se proclamou a República Federativa do Brasil e a Constituição da República dos Estados Unidos do Brasil.

Esta Constituição não somente aboliu o sistema imperial e estabeleceu a república, mais do que isso, transformou o sistema de províncias em Estados, extinguindo aquele modelo centralizado de política existente durante o período imperial e criando um sistema de divisão de poderes mais próximo daquele que atualmente se apresenta equilibradamente dividido entre o Executivo, o Legislativo e o Judiciário.

É interessante notar que, logo após a eleição de Marechal Deodoro da Fonseca à Presidência da República, a Assembleia Constituinte, que havia promulgado o texto constitucional, automaticamente se converteu em Congresso Nacional, separado em um sistema bicameral, representado pela Câmara dos Deputados e pelo Senado Federal ${ }^{37}$.

Dessa forma, buscou-se se estruturar um Parlamento hábil e garantir certo controle político sobre as ações do Poder Executivo.

Com um poder de direito e não de fato, o Legislativo em muito pouco contribuiu para a consolidação da democracia durante esse primeiro período da República. No que se refere ao sistema federalista, representado no Parlamento pelo Senado Federal, pode-se dizer que pouca inovação trouxe durante a vigência da Constituição de 1891.

È certo que a Constituição descentralizou atribuições e poderes entre as demais esferas da federação. Entretanto, não seria só necessária a descentralização de atribuições com 0 fulcro de se promover um compartilhamento do poder central. Era necessário também realizar uma distribuição fiscal, orçamentária e tributária, para que, finalmente, os poderes

xx $\mathrm{O}$ manifesto republicano teria sido uma reação dos liberais à nomeação de um gabinete ultraconservador pelo Imperador D. Pedro II. A criação de um centro liberal, que aglutinaram progressistas e liberais históricos que viviam em guerra no Parlamento, permitiu a propagação dos ideais libertários, em face do avanço do poder moderador ${ }^{80}$. 
locais pudessem obter autonomia em relação ao poder central, o que de fato, não ocorreu.

Dessa forma, criou-se no Brasil, um sistema de dependência entre governadores e o presidente da República que ficou conhecido como a política do coronelismo.

Nem mesmo com a emenda no. 26 feita no texto constitucional, que tentou disciplinar o exercício das autonomias estaduais, conseguiu mudar esse quadro de total submissão dos governadores e, por consequência, do próprio Parlamento ao Poder Executivo Central ${ }^{38}$.

Prevaleceu, pois, um regime oligárquico e opressor, sem que o Parlamento, ao final da Primeira República Civil, tivesse condições de opinar ou alterar os rumos da nação, antidemocraticamente, tomados pelo Presidente da República em um processo que nada beneficiava o debate ideológico.

\subsubsection{O Legislativo na Constituição de 1934 e o bicameralismo de 1937}

A Constituição de 1934 pode ser considerada uma das mais inovadoras da história brasileira, pois se cristaliza um modelo de democracia social imprescindível para as transformações do país e, ainda, fortalece o modelo federativo de Estado, tal qual como se havia pensado anteriormente, mas esquecido pela completa submissão dos governadores e dos membros do Parlamento aos interesses do Presidente da República.

Dessa forma, a Carta Magna de 1934 estabelecia que o Poder Legislativo era formado pela Câmara dos Deputados e pelo Senado Federal, sendo, a este último, só foram atribuídos poderes específicos para legislar somente sobre determinadas matérias, dentre as quais se pode destacar 0 Estado de sítio, o sistema eleitoral e de representação, tributos e tarifas, tratados e convenções estrangeiras e ainda, promover a coordenação dos Poderes federais entre $\mathrm{si}$, manter a continuidade administrativa e zelar pelo fiel cumprimento da Constituição, bem como praticar outros atos de sua competência.

Um Senado enfraquecido e com poderes limitados não parecia apto a realizar essa coordenação e, tampouco, se sobrepor como órgão independente 
integrante do Poder Legislativo. Diante de seu acaso, não demorou para que a constituição de 1937 viesse a extingui-lo.

Um controle efetivo do Parlamento sobre as ações do Executivo foi um dos fatores decisivos para a guinada autoritária de Getúlio Vargas em 1937 com a consequente outorga de um novo texto constitucional que drasticamente reduzira as atribuições do Legislativo, com sua total subserviência ao Executivo centralizado.

Na verdade, tanto o Parlamento, quanto o Pacto Federativo e o Estado Democrático de Direito, restaram comprometidos com a nova Constituição outorgada. Essa, por sua vez, serviu única e exclusivamente como instrumento legitimador do poder autoritário do Presidente da República.

A Constituição de 1937 aboliu a existência do Senado Federal, embora tenha mantido o sistema bicameral com a criação do Conselho Federal ${ }^{X X I}$ e o funcionamento independente de ambas as instituições, sendo a junção das casas uma exceção ${ }^{38}$.

Este Conselho seria composto de representantes dos Estados e de membros nomeados pelo próprio Presidente da república com mandato de seis anos. Os Estados, por meio de suas assembleias, elegeriam um representante sendo facultado ao governador vetar a escolha feita. A composição desse órgão era de trinta membros, sendo vinte deles eleitos pelas Assembleias Legislativas dos Estados e dez pelo próprio Presidente da República.

\subsubsection{A redemocratização de 1946 e a atividade legislativa}

O ressurgimento do Legislativo ocorre após a publicação da Lei Complementar nº. 09 de 1945 pelo Poder Executivo, convocando novas eleições para o Parlamento. De acordo com a referida Lei, o ressurgimento do Congresso

\footnotetext{
XX| Eis o teor do art. 38 da Constituição de 1937:

"Art 38 - O Poder Legislativo é exercido pelo Parlamento Nacional com a colaboração do Conselho da Economia Nacional e do Presidente da República, daquele mediante parecer nas matérias da sua competência consultiva e deste pela iniciativa e sanção dos projetos de lei e promulgação dos decretos-leis autorizados nesta Constituição.

$\S 1$ 1- O Parlamento nacional compõe-se de duas Câmaras: a Câmara dos Deputados e o Conselho Federal.

$\S 2^{\circ}$ - Ninguém pode pertencer ao mesmo tempo à Câmara dos Deputados e ao Conselho Federal".
} 
teria como principal objetivo a reforma da Constituição outorgada, influenciando todos os Estados e municípios.

Em 02 de fevereiro de 1946 foi instalada a nova Assembleia Nacional Constituinte composta de Deputados e Senadores e responsáveis pela elaboração do novo texto constitucional. A ideia do bicameralismo não mais parecia um obstáculo para o país, pois serviria para balancear os crescentes anseios populares nesse processo de redemocratização do País.

\begin{abstract}
Em face do ramo popular do Congresso, que é forçado ao contato frequente com o eleitorado, partilha das paixões e erros momentâneos do povo e timbra em refletir os desejos imediatos da multidão, é colocado o Senado, mais conservador, composto de membros menos numerosos, com idade superior a 35 anos e um mandato correspondente em duração a duas vezes 0 dos deputados, o que resulta a desnecessidade e cortejar muito as turbas volúveis e deliberantes, imprevidentes e injustas ${ }^{39}$.
\end{abstract}

Dessa forma o Senado retorna ao cenário nacional como a casa da ponderação e com a missão de coibir os abusos que a Câmara dos Deputados pudesse vir a exercer em seu processo de deliberação legislativa.

Com o processo de redemocratização trazido pela nova Carta constitucional e a consequente descentralização de atribuições aos demais entes da federação, a estrutura do Estado brasileiro sofreu uma significativa alteração com a participação efetiva dos governadores e prefeitos nos rumos da política nacional.

Os interesses dos estados e municípios voltaram a ser de fundamental importância no processo de elaboração de políticas públicas e, com isso, a sua representação nacional precisava ser forte. Assim criou-se, pois, o sistema de representação proporcional no Senado e na Câmara dos Deputados, em que a distribuição dos mandatos operar-se-ia de modo que o número de representantes fosse dividido em relação aos cidadãos ${ }^{41}$.

Com isso, conclui-se que a Constituição de 1946 dotou o Legislativo dos devidos instrumentos democráticos aptos a transformá-lo em um poder de fato, contudo, infelizmente, esse modelo de Parlamento mais representativo pereceu com a promulgação da Carta de 1967, conforme será tratado a seguir. 


\subsubsection{O regime militar: novo modelo de funcionalismo do Congresso}

Inicialmente é importante observar-se que o Parlamento foi o principal responsável pela ascensão dos ideais da ditadura e pela consequente tomada do poder de 1964, como afirma Afonso Arinos:

A Câmara dos Deputados de 1959 pode ser considerada um espelho fiel
das contradições de interesses e de conflitos ideológicos que iriam
submergir à falsa imagem dos partidos, destruir as instituições
democráticas e provocar a intervenção das Forças Armadas ${ }^{40}$.

As legendas já não mais refletiam os ideais políticos de seus partidos, dos seus Estados e de seus municípios, permitindo que os parlamentares agissem de acordo com suas convicções pessoais e não em conformidade com o clamor social.

No Senado, a questão não parecia diferente. Muitos políticos que haviam logrado êxito no período da ditadura de Vargas representavam, naquele momento, a defesa do pacto federativo na Câmara Alta. Dessa forma, a possibilidade de uma ditadura não parecia tão estranha a esses representantes.

A instauração do parlamentarismo pela Emenda Constitucional aprovada pelo Congresso de 2 de setembro de 1961 não colocou o Parlamento em melhores condições da que se encontrava, pelo contrário, este instrumento serviu apenas para acirrar os ânimos entre as Forças Armadas e o governo civil, que não encontrava respaldo no Congresso para a aprovação de suas reformas de base.

Assim, a ascensão do comando militar não encontrou obstáculos para se impor logo após a deposição de João Goulart do poder.

O Ato Institucional de 9 de abril de 1964 manteve aparentemente a ordem constitucional de 1946, mas impôs severas cassações de mandatos e suspensão de direitos políticos, permitiu a eleição de Castelo Branco por um período de três anos, o que deu legitimidade ao presidente indiretamente escolhido para elaborar outros atos institucionais ${ }^{41}$.

Por esse primeiro ato, o regime outorgou a si mesmo poderes temporários, aprovando, mediante decretos-leis, legislações fundamentais para fortalecer o seu poder. 
O Ato Institucional no. 3 de 05 de fevereiro de 1966, por sua vez, regulamentou os procedimentos a serem adotados pelo Congresso no processo de votação da nova Constituição.

A Constituição de 1967, bem como a Emenda Constitucional ‥ 1/69, trazia em sua estrutura elementos bastantes semelhantes ao texto constitucional de 1937, ou seja, fortaleceu o Poder executivo por intermédio dos decretos-leis e pela redução da autonomia dos entes federados ao reformular o sistema tributário nacional, tornando-o mais rigoroso e ampliando a técnica do federalismo com o advento do federalismo cooperativo.

Com a cassação de mandatos parlamentares e o exílio de líderes políticos contrários aos ditames ditatoriais, o Congresso Nacional perdeu a sua identidade e tornou-se um mero apêndice do Poder Executivo.

A oposição a este regime representada pelo Movimento Democrático Brasileiro tentou por diversas vezes retardar ao máximo a aprovação de leis, contudo o Presidente Geisel editou, em 13 de abril de 1977, o chamado "Pacote de Abril", que representava uma série de medidas baixadas após o atrito entre o Congresso e o executivo por conta da ausência da maioria governamental necessária para a aprovação de algumas emendas à Constituição. O Presidente, em resposta, colocou o Congresso em recesso e, a partir daí, emendou a Constituição e baixou vários decretos-leis. Entre estas medidas do pacote estava a criação da figura do senador biônico, cujo objetivo era impedir que o Movimento Democrático Brasileiro, principal partido de oposição, viesse a ser majoritário no Senado.

O critério de representação proporcional nas eleições à Câmara dos Deputados foi alterado de modo a favorecer os estados do Nordeste. Além disso, o pacote estendeu as restrições da Lei Falcão às eleições para o Legislativo Federal e Municipal. O mandato do Presidente da República passou de cinco para seis $\operatorname{anos}^{42}$.

Essa estrutura congressual prevaleceu incólume até mesmo durante 0 processo de votação da Proposta de emenda à Constituição de autoria do Deputado Dante de Oliveira, que estabelecia as eleições diretas para Presidente da república, quando o governo militar conseguiu maioria parlamentar para derrubar a referida proposta. 
Após a aprovação da Emenda Constitucional n․ 26 de 27 de novembro de 1985 que convocou a nova Assembleia Nacional Constituinte, e com as eleições de 1986, é que o Congresso retomou a sua identidade política.

\subsubsection{A Constituição de 1988 e a participação social}

Primeiramente é relevante destacar que o Congresso, desde 1986, assumira um papel de protagonista nas mudanças políticas que urgiam no Brasil $^{43}$.

Após a morte de Tancredo Neves, José Sarney, ainda que sem total convicção até pelo seu passado de ligação com o regime militar, deu continuidade ao processo de abertura democrática e enviou ao Congresso a Emenda $n^{\circ} .26^{\mathrm{XXII}}$, que, além de convocar a Assembleia Nacional Constituinte, decidiu que o processo de elaboração da nova Constituição dar-se-ia da composição congressual oriunda das eleições de 1986, formada por líderes sindicais, representantes ruralistas, intelectuais, empresários, profissionais liberais etc.. A heterogeneidade ali presente seria capaz de impulsionar um processo dialético de grandes proporções a ponto da nova Carta Constitucional ser um reflexo dessa pluralidade de pensamentos e valores.

A Constituição de 1988 fiou sua legitimidade na participação social e na possibilidade da democracia representativa efetivamente exercida. A referida Carta também ficou conhecida como a Constituição Cidadã.

A partir disso, com a nova ordem democrática, uma série de medidas legislativas infraconstitucionais precisou ser adotada para dar fim aos decretos-lei criados durante o regime de exceção.

Não só isso, era fundamental preparar a nação para o processo eleitoral que se vislumbraria com as eleições diretas para Presidente da República.

XXII Eis parte do teor da Emenda Constitucional no.26/85:

"Art. $1^{\circ}$. Os membros da Câmera dos Deputados e do Senado Federal reunir-se-ão, unicameralmente, em Assembleia Nacional Constituinte, livre e soberana, no dia $1^{\circ}$ de fevereiro de 1987, na sede do Congresso Nacional.

Art. 2․ O Presidente do Supremo Tribunal Federal instalará a Assembleia Nacional Constituinte e dirigirá a sessão de eleição de seu Presidente.

Art. 3․ A Constituição será promulgada depois da aprovação de seu texto, em dois turnos de discussão e votação, pela maioria absoluta dos Membros da Assembleia Nacional Constituinte". 
Assim, a Carta Magna estruturou um Parlamento apto a assumir novas funções, capaz de interagir com a sociedade e, juntamente com os demais Poderes da república, buscar soluções para os problemas sociais, bem como ser um poder apto a construir um arcabouço normativo capaz de impulsionar todas as transformações. 


\section{DIREITO NUCLEAR BRASILEIRO: COMPETÊNCIA LEGISLATIVA}

\subsection{Elementos do processo legislativo e o processo de formação das Leis}

A partir da constatação de que existe um processo legislativo, é importante compreender de como é feito, quais os seus reflexos na sociedade, qual a sua eficácia e a sua aplicabilidade.

Destarte que, no presente capítulo estar-se referindo o processo legislativo em todas as esferas hierárquicas, ou seja, federal, estadual e municipal, pois o sistema jurídico é dinâmico por conta da interdependência de normas em uma cadeia de transmissão de autoridade. Se ele é uno, se ele esta fundado na lógica do "inteiro sistema" e se, ao mesmo tempo, novas normas são inseridas ou retiradas a todo tempo, ele é mutante. A geometria do ordenamento pode ter características estáticas, formato rígido, mas seu conteúdo muda a todo tempo, com sucessivas adaptações, constantes alterações, adições, supressões, substituições e assim por diante.

Nesta linha, é necessário analisar as características do ordenamento jurídico e do processo legislativo brasileiro para, a partir daí, tentar esclarecer paralelo de como ele é e de como ele deveria ser, principalmente no que se refere a utilização da Energia nuclear. Construindo esse cenário, pode-se tentar propor metodologias de organização e interpretação que se coadunem com o dinamismo das mutações de conteúdo, como se verá a seguir. 


\title{
5.1.1 Definição e principais modalidades de norma
}

O art. 59 da Constituição a República Federativa do Brasil de 1988 diz que o processo legislativo compreende a elaboração de emendas a Constituição, leis complementares, leis ordinárias, leis delegadas, medidas provisórias, decretos legislativos e resoluções.

Muito representativo do caos legislativo é fato do próprio artigo constitucional, que é dedicado a tipologia das normas, ser impreciso. Destarte que no presente capítulo, não se esta se referindo ao direito internacional regulamentador da proteção radiológica, pois a própria definição de norma já é contraditória quando comparado com o âmbito jurídico nacional ${ }^{\mathrm{XXIII}}$.

Pelas explicações de José Afonso da Silva, tem-se a dimensão de como é confusa a atividade legislativa no Brasil:

\begin{abstract}
As medidas provisórias não constavam da enumeração do artigo 59 , como objeto do processo legislativo, e não tinham mesmo que constar, porque sua formação não se dá por processo legislativo. São simplesmente editadas pelo Presidente da República. A redação final da Constituição não as trazia nessa enumeração. Um gênio qualquer, de mau gosto, ignorante e abusado, introduziu-as aí, indevidamente, entre a aprovação do texto final (portanto depois do dia 22.9.88) e a promulgação-publicação da Constituição no dia 05 de outubro de $1988^{44}$.
\end{abstract}

Como se não bastasse, e somando a tudo isso, há normas de caráter cooperativo, ou seja, há regras que tem origem as decisões em caráter vinculante dos Tribunais, tudo isso multiplicado por Municípios e estados, cuja fabricação legislativa própria impõe ao operador do direito uma quantidade gigantesca de normas, que cresce cada vez mais e confunde a vida do cidadão.

Mas, voltando às espécies de normas do ordenamento pátrio, vale codificá-las, mesmo que brevemente, de forma individualizada.

Inicialmente, estudava-se as emendas constitucionais que possuem a mesma natureza e a mesma força hierárquica da Constituição, sendo o instrumento capaz de modificá-la. A Carta Magna brasileira, como já dito

XXIII É importante observar que norma pode ser entendida em dois aspectos: da proteção radiológica e o jurídico. No que se refere ao aspecto da proteção radiológica, as normas são recomendações sem caráter obrigatório e vinculante. Prevalece 0 interesse e o consenso das partes. Já os regulamentos são obrigatórios a todos os agentes.

No âmbito jurídico, normas são regras gerais e permanentes a que todos estão submetidos. São obrigatórias e estabelecidas por Direito. Já os regulamentos são estatuto que prescrevem o que se deve fazer ${ }^{76}$. 
anteriormente, é rígida, portanto, há um procedimento legislativo especial para a elaboração das emendas.

No que se refere às leis complementares, são aquelas normas aprovadas por maioria absoluta, em um turno de votação, em ambas as Casas do Congresso Nacional e de campo normativo expressamente delimitado pela Constituição Federal. Difere da lei ordinária em dois aspectos: o quórum de aprovação (a lei complementar deve ser aprovada por maioria absoluta; já a lei ordinária, por maioria simples ou relativa) e a matéria a ser disciplinada (somente será exigida a edição de lei complementar quando a Constituição expressamente indicar; não havendo qualquer exigência expressa, a matéria poderá ser regulamentada por lei ordinária). Exemplo de leis Complementares: imposto sobre grandes fortunas, de competência da União (art. 153, VII, da $\mathrm{CF} / 88)$.

A lei ordinária é a lei comum, ou seja, o ato normativo que edita normas gerais e abstratas (ato legislativo típico) ${ }^{45}$. Será elaborada pelo Congresso Nacional, na área federal, pela Assembleia Legislativa, em nível estadual, e pela Câmara dos Vereadores, no âmbito municipal. A matéria é aquela não compreendida pela lei complementar, dispondo de maneira geral e impessoal. Segue o processo mencionado acima, de forma geral. Sua aprovação se dá por maioria simples ou relativa, ou seja, a maioria dos votos de cada Casa, em um turno de votação, presente no mínimo a maioria dos seus membros.

Já as leis delegadas, estas se equiparam à lei ordinária, porém, delas diferem porque serão elaboradas pelo Presidente da República. A delegação do Poder Legislativo se dá por resolução do Congresso Nacional, mediante prévia solicitação do Presidente da República, que especificará seu conteúdo e os termos de seu exercício.

Não será objeto de delegação os atos de competência exclusiva do Congresso Nacional, os de competência privativa da Câmara dos Deputados ou do Senado Federal, a matéria reservada à lei complementar nem a legislação sobre: planos de orçamento, organização do Ministério Público e do Poder Judiciário, questões referentes à nacionalidade, cidadania, direitos individuais, políticos e eleitorais.

A resolução do Congresso pode estabelecer uma delegação pura e simples, caso em que o Presidente elabora a lei delegada, promulga-a e publica- 
a; ou pode determinar que, após sua elaboração pelo Presidente da República, deverá ser devolvida ao Congresso, que a apreciará em sessão conjunta, vedada qualquer emenda. Nesta segunda hipótese, a rejeição da lei delegada pelo Congresso Nacional é denominada veto parlamentar.

No que se refere às medidas provisórias, são normas com força de lei que, em caso de relevância e urgência, o Presidente da República poderá editar, devendo submetê-las de imediato ao Congresso Nacional.

São editadas por um período de sessenta dias, sendo admitida uma única prorrogação, pelo mesmo prazo. Serão possíveis três ocorrências: aprovação com ou sem alteração do texto (se a medida provisória for aprovada com alterações, deverá o Congresso Nacional aprovar um projeto de lei de conversão, que é o veículo das mudanças); rejeição expressa ou rejeição tácita. Se não apreciadas pela Câmara em quarenta e cinco dias, entram na ordem do dia e bloqueiam a pauta. Se forem rejeitadas, arquivam-se.

Saindo da Câmara, dirigem-se ao Senado, que também tem quarenta e cinco dias para apreciá-las. Se a medida provisória for rejeitada ou não apreciada, perde seus efeitos desde a sua edição.

O Congresso Nacional, então, deverá, por meio de decreto legislativo, regular as relações advindas do período em que ela vigorou no prazo de sessenta dias. Caso não o faça, as relações jurídicas constituídas durante o período em que vigorou continuarão por ela regidas.

As medidas provisórias que foram editadas antes da Emenda Constitucional no. 32/2001 perdurarão até que venham outras e as revoguem ou até que o Congresso delibere em sentido contrário.

É vedada a edição de medidas provisórias sobre matéria relativa a: nacionalidade, cidadania, direitos políticos, partidos políticos e direito eleitoral; direito penal, processual penal e processual civil; organização do Poder Judiciário e do Ministério Público, a carreira e a garantia de seus membros; planos plurianuais, diretrizes orçamentárias, orçamento e créditos adicionais e suplementares, ressalvado o previsto no art. 167, § $3^{\circ}$ da Carta Magna brasileira; que vise à detenção ou sequestro de bens, de poupança popular ou qualquer outro ativo financeiro; reservada a lei complementar; já disciplinada em projeto de lei aprovado pelo Congresso Nacional e pendente de sanção ou veto do Presidente da República. 
O decreto legislativo é a espécie normativa veiculadora das competências exclusivas do Congresso Nacional. Não é submetido à sanção ou veto do Presidente da República. É promulgado pelo Presidente do Senado Federal. Pode veicular matérias concretas ou atos normativos. Exceção: a delegação de competência que ocorre do Poder Legislativo ou Poder Executivo na lei delegada se opera por resolução.

Por fim, a resolução, ou seja, espécie normativa veiculadora das competências privativas da Câmara dos Deputados, do Senado Federal e de algumas competências do Congresso Nacional. Não está sujeita à sanção ou veto presidencial. A promulgação é feita pela Mesa da Casa Legislativa que a editou.

\subsubsection{A lógica e o funcionamento do processo de formação legislativa}

Inicialmente é importante verificar se o processo legislativo é o conjunto de atos que deverão ser observados pelos órgãos competentes para a produção, criação, modificação ou revogação de normas gerais. São fases do processo legislativo: introdutória; constitutiva (deliberação parlamentar e deliberação executiva); e complementar (promulgação e publicação).

1) Fase introdutória também conhecida como iniciativa legislativa é a faculdade que se atribui a alguém ou a algum órgão de apresentar projeto de lei ao Legislativo (art. 61 da CF/88). A iniciativa pode também ser conferida aos cidadãos. Se o projeto decorrer de iniciativa do Presidente da República, da Câmara dos Deputados, dos Tribunais Superiores, do Procurador-Geral da República ou mesmo de iniciativa popular (art.64 da Carta Magna), a discussão se inicia na Câmara dos Deputados. No entanto, se a iniciativa for de membro ou comissão do Senado, a discussão se inicia no próprio Senado.

No entanto, a iniciativa popular (art. 61, caput, combinado com o $§ 2^{\circ}$ do mesmo diploma legal) determina que o projeto de lei seja subscrito por, no mínimo, $1 \%$ (um por cento) do eleitorado nacional, distribuído pelo menos por cinco estados, com não menos de $0,3 \%$ dos eleitores de cada um. Será apresentado perante a Câmara dos Deputados.

2) Deliberação parlamentar também denominada de discussão e votação, ou seja, o projeto aprovado por uma Casa será revisto pela outra, em um 
só turno de discussão e votação em cada uma. Na Casa revisora, pode o projeto ser rejeitado (sendo arquivado); ser aprovado (com posterior remessa ao Poder Executivo para sanção ou veto) ou ser emendado.

A aprovação:

a) quando se tratar de projeto de lei ordinária será por maioria simples, ou seja, maioria dos votos dos membros presentes, desde que presente, no mínimo, a maioria absoluta dos membros (art. 47 da Constituição da República Federativa do Brasil de 1988);

b) quando se tratar de lei complementar será por maioria absoluta (mais da metade dos membros);

c) quando se tratar de Emenda Constitucional (art. 60, § 2º, da CF/88), será por $3 / 5$ dos membros.

Ressalva-se que a emenda é a proposta de alteração do projeto. $\mathrm{O}$ poder de emendar é inerente à função legislativa. Em regra, todos os projetos podem ser emendados, exceto os de iniciativa reservada quando deles resultar aumento de despesas.

As emendas podem ser:

a) supressivas: visam erradicar uma parte da proposição;

b) aditivas: acrescem algo ao projeto;

c) modificativas: alteram a proposição inicial, mas não a essência dela;

d) substitutivas: alteram a essência da proposição;

e) aglutinativas: resultam no agrupamento de diversas emendas.

O projeto emendado deve retornar à Casa iniciadora, que pode concordar com a emenda e remeter o projeto ao Poder Executivo; ou discordar, fazendo prevalecer à vontade de quem fez a deliberação principal (princípio da primazia da deliberação principal).

3) Deliberação executiva, sanção ou veto é ato de competência exclusiva do Presidente da República. A Casa, na qual tenha sido concluída a votação, enviará o projeto ao Presidente da República (autógrafos), que, aquiescendo, o sancionará. Ocorre apenas no processo das leis ordinárias e complementares.

No que se refere à sanção, é a concordância do chefe do Executivo (Presidente da República) com o projeto de lei aprovado pelo Legislativo, podendo ser expressa (assinatura do projeto pelo Presidente) ou tácita (ausência 
de manifestação no prazo quinze dias após o recebimento) - art.66, $\S \S 1^{\circ}$ a $7^{\circ}$, da CF/88. O $\S^{\circ}$ do art. 66 da Constituição da República Federativa do Brasil de 1988 dispõe que o Presidente tem quinze dias úteis para vetar o projeto de lei.

Por fim, o veto é a discordância do Presidente com o projeto aprovado, sempre de forma expressa, podendo ser total ou parcial, por entendê-lo inconstitucional (veto jurídico) ou contrário ao interesse público (veto político). Tem o prazo de quinze dias úteis para apresentá-lo, devendo, dentro de 48 horas, comunicar os motivos do veto ao Presidente do Senado Federal.

O veto poderá ser "derrubado" pelo Congresso, em sessão conjunta, dentro de trinta dias a contar do seu recebimento, só podendo ser rejeitado pelo voto da maioria absoluta dos Deputados e Senadores, em escrutínio secreto.

Após, o projeto será reenviado ao Presidente da República para a promulgação. Não o fazendo, caberá ao Presidente do Senado ou ao VicePresidente dessa Casa. As principais características do veto são: ser expresso, ser motivado, ser formalizado, ser superável e ser supressivo.

4) Fase complementar: se divide em promulgação e a publicação. A Promulgação é ato do Presidente da República, pelo qual proclama a lei, comunicando aos seus destinatários que ela foi criada. A produção de seus efeitos está condicionada a ela. Deve ser realizada quarenta e oito horas após a sanção ou após a derrubada.

\subsubsection{As comissões parlamentares no processo legislativo brasileiro}

Já se afirmou anteriormente que as comissões desempenham um papel fundamental no funcionamento do Poder Legislativo, caberá agora uma análise detida desses órgãos colegiados.

As comissões são grupos menores de parlamentares, reunidos para apreciar determinados assuntos. Podem ser:

a) permanentes: são aquelas formadas no início de cada legislatura ordinária, competindo-lhes o exame dos projetos de lei concernentes à matéria de sua competência, constituídas na forma e com as atribuições previstas no respectivo regimento interno do Congresso Nacional e de suas Casas. Ex.: Comissão de Constituição e Justiça que exerce um papel fundamental no controle prévio de constitucionalidade dos atos normativos. Embora não 
vinculante, muitos projetos de lei acabam arquivados pelas respectivas mesas justamente por estarem em desacordo com o texto constitucional ou por se tratarem de mera conveniência política. Há também a Comissão de Orçamento e de Defesa que é responsável pelo bom andamento dos instrumentos normativos no que se refere a situação financeira do país.

b) temporárias: são aquelas criadas pelo Congresso Nacional ou por qualquer de suas Casas para deliberar sobre determinado fato, e geralmente têm o seu prazo circunscrito a cada legislatura. Ex.: Comissão para a elaboração do Código Civil, Comissão Parlamentar de Inquérito (CPI).

c) representativas: novidade da $\mathrm{CF} / 88$, representam o Congresso Nacional durante o recesso parlamentar, visando à não interrupção das atividades.

\subsection{A Competência legislativa no Direito Nuclear Brasileiro}

Como já visto anteriormente, o atual modelo constitucional encampou o modelo federalismo de três níveis: a União; os estados e o Distrito Federal, e os Municípios. O sistema previsto na Constituição da República Federativa do Brasil de 1988 é baseado em um complexo sistema de repartição de competências materiais, legislativas e tributárias, congregando critérios de ótica horizontal e vertical de competências.

É importante ressaltar que a Carta Magna contemplou ainda, competências comuns e hipóteses de delegação de competências da União para os estados membros, com fundamento ideológico no federalismo de equilíbrio $^{\mathrm{XXIV}}$, conforme $\mathrm{o}$ art. 22 , parágrafo único do referido diploma legal ${ }^{\mathrm{XXV}}$.

A Constituição cidadã adotou o complexo de distribuição de competências a busca pelo equilíbrio federativo ${ }^{44}$. Recompôs-se, dessa forma, a estrutura dos poderes entre a união e os demais entes federados, corroborada pela instituição de mecanismos de correção das disparidades econômicas e

\footnotetext{
XXIV "O federalismo equilíbrio traduz a ideia de que os entes federativos devem manter-se em harmonia, reforçando-se as instituições" ${ }^{\prime 1}$.

$\mathrm{XXV}$ "Art. 22. Compete privativamente à União legislar sobre: (...)

XXVI - atividades nucleares de qualquer natureza. (...)

Parágrafo único. Lei complementar poderá autorizar os Estados a legislar sobre questões específicas das matérias relacionadas neste artigo".
} 
sociais das regiões, a redistribuição de rendas entre os entes federados de alguns impostos, o planejamento regional de investimentos e incentivos fiscais. Vivenciase, assim, o federalismo de equilíbrio.

A peculiaridade mais significativa do federalismo brasileiro foi a tripartição dos entes federados, diante da elevação dos municípios a membro integrante da Federação Brasileira, nos termos dos arts. $1^{\circ}$ e 18 da CF/88 XXV! .

O modelo constituinte atribui ao município competências próprias, autonomia política e tributária, bem como a capacidade de auto organização, por meio da lei orgânica municipal e autogoverno através de prefeitos eleitos diretamente pelo povo. Contudo, não atribui aos municípios representação no Senado Federal. Dessa forma, se dá a seguinte inovação nacional:

O município faz parte do concerto nacional, orquestrado pela essência federativa, a unicidade nacional em convivência com a autonomia local, onde o povo agora pode decidir sobre os rumos da política municipal nos interesses de suas peculiaridades ${ }^{46}$.

Assim, a técnica utilizada pelo constituinte para repartição das competências aos entes federativos foi primeiramente a de definição das competências materiais e administrativas ${ }^{X X V I I}$ da União (art. 21 da CF/88),

XXVI “Art. $1^{\circ}$ A República Federativa do Brasil, formada pela união indissolúvel dos Estados e Municípios e do Distrito Federal, constitui-se em Estado Democrático de Direito e tem como fundamentos:

I - a soberania;

II - a cidadania

III - a dignidade da pessoa humana;

IV - os valores sociais do trabalho e da livre iniciativa;

$\mathrm{V}$ - o pluralismo político.

Parágrafo único. Todo o poder emana do povo, que o exerce por meio de representantes eleitos ou diretamente, nos termos desta Constituição".

"Art. 18. A organização político-administrativa da República Federativa do Brasil compreende a União, os Estados, o Distrito Federal e os Municípios, todos autônomos, nos termos desta Constituição.

$\S 1^{\circ}$ Brasília é a Capital Federal.

$\S 2^{\circ}$ Os Territórios Federais integram a União, e sua criação, transformação em Estado ou reintegração ao Estado de origem serão reguladas em lei complementar.

$\S 3^{\circ}$ Os Estados podem incorporar-se entre si, subdividir-se ou desmembrar-se para se anexarem a outros, ou formarem novos Estados ou Territórios Federais, mediante aprovação da população diretamente interessada, através de plebiscito, e do Congresso Nacional, por lei complementar.

$\S 4^{\circ}$ A criação, a incorporação, a fusão e o desmembramento de Municípios, far-se-ão por lei estadual, dentro do período determinado por Lei Complementar Federal, e dependerão de consulta prévia, mediante plebiscito, às populações dos Municípios envolvidos, após divulgação dos Estudos de Viabilidade Municipal, apresentados e publicados na forma da lei".

XXVII As competências materiais ou administrativas são distribuídas da seguinte forma:

a) competências exclusivas: são as atribuídas a uma entidade com exclusão das demais, portanto, indelegáveis. Prevê a Constituição a competência exclusiva: enumerada da União (art. 21 da 
posteriormente arrolou, em sintonia com as atribuições administrativas, as suas competências legislativas privativas ${ }^{\mathrm{XVIII}}$ (art. 22 da CF/88). Aos estados foi deferida a competência remanescente não enumerada (art. $25, \S 1^{\circ}$ da CF/88). Por sua vez, os Municípios receberam poderes estabelecidos indicativamente quando presente o interesse local, tanto para legislar quanto para administrar, bem como suplementar a legislação federal e estadual no que couber.

A competência legislativa concorrente finca-se no art. 24 da Constituição da República Federativa do Brasil de 1988, onde se positiva a repartição vertical de competências, cabendo às normas gerais à União e a legislação suplementar aos estados. Há, ainda, as competências administrativas comuns, donde decorre a competência legislativa imprópria e indireta aos entes federados (art. 23 da CF/88), conforme se verá adiante. Eis a repartição vertical de competência na esteira do modelo germânico, inspiração do constituinte, com alternativas para se alcançar o balanceamento necessário para um federalismo de equilíbrio e a integração legislativa dos entes federados nas diferentes searas

CF/88); enumerada dos Municípios (art. 30 da CF/88); enumerada dos Estados (art. 25, § $2^{\circ}$ da $\mathrm{CF} / 88$ ); e reservada dos Estados (art. 25, $\S 1^{\circ}$ da $\mathrm{CF} / 88$ ).

b) competências comuns ou paralelas (art. 23 da CF): são as exercidas por todos os entes federados conjuntamente. Decorrem do denominado federalismo cooperativo. A lei complementar deverá fixar normas de cooperação entre os entes federativos.

Exs.: proteger o meio ambiente, preservar florestas, a fauna e a flora, combater as causas de pobreza e os fatores de marginalização.

xxVIII Cada esfera federativa possui um rol próprio de competências, as quais, salvo hipótese de delegação, deve exercer com exclusão das demais. As competências legislativas são exercidas pelo Poder Legislativo de cada ente federado. Podem ser:

a) Competência privativa (art. 22 da CF/88), enumerada como própria de uma entidade, com possibilidade, no entanto, de delegação ou de competência suplementar.

Dessa forma, tem-se que tais competências pertencem, em princípio, à União, mas podem ser delegadas aos Estados-membros, por meio de lei complementar, para que legislem sobre questões específicas de seus interesses. Exs.: Direito civil, comercial, penal, processual e eleitoral, desapropriação, seguridade social.

b) Competência concorrente (art. 24 da $\mathrm{CF} / 88$ ), exercida por mais de um ente federado, de acordo com regras traçadas na Constituição para sua distribuição. Sendo assim, a União por lei federal dispõe sobre normas gerais; os Estados e o Distrito Federal podem suplementar essa legislação. Inexistindo lei federal, os Estados podem legislar plenamente. Na superveniência de lei federal, os dispositivos da lei estadual incompatíveis com a norma geral têm sua eficácia suspensa. Exs.: Direito tributário, financeiro, econômico, urbanístico e penitenciário, caça, pesca, flora, cultura, educação, desporto, defesa da saúde.

c) Competência reservada (art. $25, \S 1^{\circ}$ da $\mathrm{CF} / 88$ ) dos Estados, para legislar sobre o que não estiver vedado, ou seja, sobre todas as matérias que não foram expressamente atribuídas à União nem aos Municípios.

d) Competência exclusiva (art. 30, I da CF/88) dos Municípios, para legislar sobre assuntos de interesse local.

e) Competência suplementar (art. 30, II da CF/88) dos Municípios, com relação à legislação estadual e federal. 
que atuam conjuntamente, com a delegação de competências legislativas da União aos estados.

Dada a prerrogativa conferida aos municípios para suplementar a legislação federal e estadual no que couber, isto é, quando há o interesse municipal, também há a sua participação nos contornos da competência concorrente.

Dessa forma, resumidamente, tem-se: competências legislativas privativas da União (art. 22 da CF/88); competências administrativas da União também conhecida como competências legislativas indiretas da União (art. 21 da CF/88); competências legislativas dos estados também denominadas como remanescentes (art. $25, \S^{\circ}{ }^{\circ}$ da $\mathrm{CF} / 88$ ); competências legislativas privativas dos municípios (art. 30, I da CF/88); competências legislativas concorrentes dos entes federados (arts. 24 e 30, II ambos da CF/88) e as competências administrativas comuns de todos os entes federados também chamada de competência legislativa comuns indiretas (art.23 da CF/88).

\subsubsection{A competência legislativa e privativa da União}

De início é importante relembrar que a União é um ente federado igual aos estados membros, o Distrito Federal e os municípios e, ainda, não se confunde com a República Federativa do Brasil. Essa divisão torna-se mais clara quando a União legisla para seus servidores ou para sua polícia (federal), isto é, para si própria. Contudo, a União também age em nome da Federação quando mantém relações com os Estados estrangeiros, assegura a defesa nacional ou decreta Estado de sítio e a intervenção federal (art. 21, I, II e IV da CF/88). Justamente por essa dupla atribuição, Michel Temer $^{47}$ observa que a União é uma figura de duas faces, que tanto age em nome próprio como em nome da Federação. Ora se manifesta por si, como pessoa jurídica de capacidade política, ora em nome do Estado Federal.

Daí o sentido de dizer que as leis federais alcançam somente a União (quando legisla para os seus servidores), ao passo que as leis nacionais alcançam toda a Federação (quando legisla em nome da Federação). Frise-se, pois, que quanto às normas firmadas pela União, divisão entre as normas ditas nacionais ou federais tem por base não o critério territorial de validade, mas sim o 
critério pessoal de validade da norma, consoante preconiza Hans Kelsen ${ }^{48}$, ao pontuar que as normas provindas da União, embora tenham todas as mesmas esfera territorial de validade, tendem a diferir quanto às suas esferas pessoais de validade. As normas nacionais apresentam validade pessoal para todos os entes federados; já as normas tidas como federais, vinculam somente a União, geralmente voltadas para o seu corpo administrativo, como seus servidores ou sua própria regulamentação administrativa.

Esclareça-se, ainda, que a federação é uma forma de organização interna do Estado, de que os entes federados tem personalidade jurídica de Direito publico interno, ao passo que somente a República Federativa do Brasil é pessoa de Direito internacional e soberana, isto é, instância única de poder e representatividade no âmbito externo. Por consequência só há que se falar em uma única nacionalidade para País, pois o Estado soberano é um só, a República Federativa do Brasil; os entes federados são entes autônomos, componentes da Federação.

Como já visto anteriormente, a repartição de competências é perfilhada diretamente na Constituição da República Federativa do Brasil de 1988, tipologicamente situada na organização do Estado, Título III, cujo Capítulo II trata da União Federal particularizada em 29 incisos do art. 22, que trata das competências legislativas privativas da União. Por sua vez, o art. 22, parágrafo único autoriza, mediante positivação de lei complementar, que os estados legislem sobre questão específica das matérias apontadas nos incisos arrolados no art. $22^{X X I X}$. Lembrando que dentre estas matérias apontadas estão as atividades nucleares de qualquer natureza, no inciso XXVI do referido artigo.

Competência legiferante é a atribuição constitucional do poder de legislar sobre determinado rol de assuntos a um ente federado. $O$ termo competência equipara-se à aptidão de capacidade, isto é, atribuições institucionais atribuídas ao ente político como manifestação de sua autonomia; e no âmbito de competência federal, expressão de sua soberania.

A repartição constitucional das competências é a pedra angular do federalismo, pois concretiza a descentralização política e administrativa dos entes

\footnotetext{
XXIX "Art. 22. Compete privativamente à União legislar sobre: (...)

$X X V I$ - atividades nucleares de qualquer natureza. (...)

Parágrafo único. Lei complementar poderá autorizar os Estados a legislar sobre questões específicas das matérias relacionadas neste artigo".
} 
políticos e garante, assim, maior segurança à democracia dada a existência de múltiplos centros de poder político e não apenas administrativo o que assegura melhor participação do povo na tomada de decisões e na fiscalização da res pública, marco da democracia.

Importante ainda registrar que não é só a partilha constitucional de competências que condiciona o federalismo de equilíbrio e a real autonomia dos entes federados, mas também a efetiva utilização, bem como sua aplicação e interpretação pelos tribunais.

Do mesmo modo que a competência executiva ou administrativa, a competência legislativa descrita no art. 22 não esgota a competência da União. A rigor, toda a matéria de competência da União é suscetível de regulamentação mediante lei, ressalvadas as disposições próprias do Congresso Nacional. O próprio art. 48 da CF/88 descreve outras competências legislativas, baseadas nas atribuições do Congresso Nacional para disciplinar o rol descritivo de incumbência federal. Constam, ainda, outros preceitos esparsos da Carta Magna que requerem lei federal para disciplinar prerrogativas e atribuições da União Federal.

Enquanto o art. 22 da Constituição da República Federativa do Brasil de 1988 disciplina a competência legislativa da União Federal através da técnica da divisão horizontal de competência, o art. 24 do mesmo diploma legal consubstancia as competências concorrentes.

A competência legislativa da União concentra-se basicamente sobre quatro planos, a saber:

a) Quando age em nome da Federação nas tarefas da república federativa do Brasil que guarnecem a unidade do País no trato com os demais estados soberanos e entre os entes políticos, com as normas gerais de direito, como por exemplo, a legislação sobre nacionalidade, cidadania e naturalização entre outros.

b) nas áreas de atuação estratégica para a integração nacional pelo direito, pela cultura e pela ordem social, assuntos que integram a sociedade brasileira através de regras homogêneas em todo o território nacional, como é o, por exemplo, das normas de transito e transportes, seguridade social e as normas gerais de licitação e contratação em todas as modalidades, para as 
administrações públicas diretas, autarquias e fundacionais da União, estados, Distrito federal e municípios.

c) na seara da política econômica e financeira nacional, própria do regime capitalista extensivo para todos os entes federados, como por exemplo, o estabelecimento de diretrizes e bases do planejamento do desenvolvimento nacional.

d) competências remanescentes decorrentes de atribuições materiais e de seus bens, como a legislação de jazidas, minas, outros minerais e metalurgia, e ainda, atividades nucleares de qualquer natureza.

Em que pese a topologia de sua classificação como competência legislativa privativa, alguns itens merecem ser classificados como de competência concorrente, fiel à semântica do termo e sua interpretação sistemática, como os campos normativos voltados a diretrizes da União, como é o caso das normas gerais de licitação e contratação na Administração Pública em Geral e das atividades nucleares, justamente por demandarem normas de caráter geral, de forma que não se proíbe a complementação da legislação pelos estados.

De um lado, tem-se como imperativo o caráter nacional das normas substanciais até como condição de integração nacional por meio de regras homogêneas em todo o território nacional, como é o caso da seguridade social e do direito alfandegário.

De outra banda, dada a extensão e profundidade do rol legislativo da União Federal, assiste-se no cenário nacional o que ocorre mundialmente, a universalidade da tendência fortificante da união no federalismo contemporâneo, impelida pelos fenômenos mundiais de integração que exigem presença firme e coordenada do ente central.

Lastreada nessa crítica, algumas competências poderiam ser compartilhadas (competência concorrente) e até mesmo transferidas para os demais entes federativos diante da peculiaridade de demandas em cada estado, onde a união poderia lançar os preceitos e diretrizes cogentes e os estados regras peculiares, frente a sua conjuntura geográfica social. Salutar seria a participação dos estados, os organismos regionais e municipais na elaboração das bases do planejamento de forma que se teria melhor condições de 
regulamentar seus interesses e reivindicações e, assim, otimizar seus potenciais territoriais e sociais.

\subsubsection{A competência legislativa dos Estados e do Distrito Federal}

O modelo federativo por natureza defere aos Estados-membros a autonomia legislativa condicionada, contudo, expressamente pelos princípios estruturantes da Constituição Federal. O federalismo nacional segue essa regra estrutural, nos termos do art. 25, caput da CF/88: Os estados organizam-se e regem-se pelas Constituições e leis que adotarem, observados os princípios desta Constituição. Por sua vez, o parágrafo do artigo, dispõe: "São reservadas aos estados as competências que não Ihe sejam vedadas por esta Constituição”.

Fernanda Dias Menezes de Almeida ${ }^{49}$ leciona, assim, que será, portanto, dos estados-membros tudo o que não se incluir entre as competências enumeradas da União e dos Municípios, bem como não incida no campo das vedações constitucionais - conforme a seguir explicitado. É o que chamamos de competência remanescente.

Emblemática, portanto, a ênfase constitucional da autonomia dos estados, qual seja, a liberdade politica de eleger o seu próprio governo e de prover o seu peculiar destino, através das suas próprias leis, elaboradas pelos representantes do seu povo, escolhidos no âmbito territorial do estado-membro. Eis o sentido da competência privativa dos estados, o poder de autodeterminação exercitável de modo independente na faixa de sua competência positivada pela Carta inaugural - condicionada, no entanto, aos princípios da Carta Federal.

A autonomia dos estados-membros é de importância crucial para o federalismo, tanto que a doutrina a qualifica como traço característico do Estado Federal, elemento essencial à configuração do federalismo. Assim, a autonomia dos entes federados estende-se ate os limites traçados na Constituição Federal.

Justamente por se cuidar de poder condicionado, a autonomia não se confunde com a soberania, esta é apanágio exclusivo de toda a Federação, cuja independência é máxima, enquanto que na autonomia a independência é condicionada sob o plano da federação, pelo seu espirito de unidade, direitos fundamentais, a forma de governo e os princípios estruturais. Procurar-se-á expor 
quais são esses princípios, mencionados pelo constituinte, ao condicionar a competência legislativa dos estados-membros.

A origem nacional da explicitação dos princípios condicionantes aos estados-membros adveio com a Reforma Constitucional de 1926 para o fim de melhor integrar as Constituições Estaduais, cujo exemplo mais marcante de tal necessidade foi a Constituição Estadual do Rio Grande do Sul, que adotara uma organização sui generis ${ }^{X x X}$ completamente diferente dos demais estados, o que acarretou distúrbios institucionais e políticos ${ }^{50}$.

Deveras, a história do constitucionalismo pátrio descreve um movimento pendular dessa condicionalmente federativa; inicialmente marcada por uma ampla abertura, dada a ausência de enumeração expressa desses princípios constitucionais, posteriormente assistiu-se uma intervenção excessiva nos estados-membros, marcada pelo chamado federalismo de integração na vigência Carta de 1967/69. Já o constituinte de 1988 procurou conferir maior amplitude autônoma ao Poder Constituinte decorrente, através de uma limitação condicionante mais tênue e principiológica.

As disposições fixadas nos artigos 34 a 36 da Carta Magna ${ }^{\mathrm{XXX}}$ também firmam o fulcro constitucional a ser seguido por todos os entes federados.

xxx Sui generis é uma expressão em latim que significa "de seu próprio gênero" ou "único em sua espécie". Muita utilizada no Direito, ela indica algo que é particular, peculiar, único. Reporta-se a um fato singular, por exemplo.

XXXI “Art. 34. A União não intervirá nos Estados nem no Distrito Federal, exceto para:

I - manter a integridade nacional;

II - repelir invasão estrangeira ou de uma unidade da Federação em outra;

III - pôr termo a grave comprometimento da ordem pública;

IV - garantir o livre exercício de qualquer dos Poderes nas unidades da Federação;

$V$ - reorganizar as finanças da unidade da Federação que:

a) suspender o pagamento da dívida fundada por mais de dois anos consecutivos, salvo motivo de força maior;

b) deixar de entregar aos Municípios receitas tributárias fixadas nesta Constituição, dentro dos prazos estabelecidos em lei;

VI - prover a execução de lei federal, ordem ou decisão judicial;

VII - assegurar a observância dos seguintes princípios constitucionais:

a) forma republicana, sistema representativo e regime democrático;

b) Direitos da pessoa humana;

c) autonomia municipal;

d) prestação de contas da administração pública, direta e indireta.

e) aplicação do mínimo exigido da receita resultante de impostos estaduais, compreendida a proveniente de transferências, na manutenção e desenvolvimento do ensino e nas ações e serviços públicos de saúde.

Art. 35. O Estado não intervirá em seus Municípios, nem a União nos Municípios localizados em Território Federal, exceto quando:

I - deixar de ser paga, sem motivo de força maior, por dois anos consecutivos, a dívida fundada;

II - não forem prestadas contas devidas, na forma da lei; 
Resumidamente, são a forma republicana, o sistema representativo, o regime democrático, a temporariedade das funções eletivas, a separação de Poderes, a autonomia municipal e a prestação de contas da administração pública direta e indireta. Disso decorre que o constituinte estadual deve moldar sua legislação com os mesmos predicados.

Por isso, pode-se denominar de regras de simetria os preceitos expressos na Constituição da República Federativa do Brasil de 1988 que fundam a estrutura de regência do estado, como aquelas que refletem o interrelacionamento entre os poderes, tal como disciplinado no âmbito federal. Assim, o estado-membro deve seguir dessa mesma linha quanto a relação dos Poderes, tal como decidiu o Supremo Tribunal Federal ${ }^{X X X I}$ quanto às regras básicas do processo legislativo, em especial a iniciativa reservada de lei e os limites de emenda parlamentar.

Essa orientação reconhece a inconstitucionalidade de normas estaduais que subordinam a eficácia de convênios celebrados por Secretários de estados ou de seus atos e contratos a aprovação da Assembleia Legislativa, justamente para preservar a independência e harmonia entre os Poderes.

III - não tiver sido aplicado o mínimo exigido da receita municipal na manutenção e desenvolvimento do ensino e nas ações e serviços públicos de saúde;

IV - o Tribunal de Justiça der provimento a representação para assegurar a observância de princípios indicados na Constituição Estadual, ou para prover a execução de lei, de ordem ou de decisão judicial.

Art. 36. A decretação da intervenção dependerá:

I - no caso do art. 34, IV, de solicitação do Poder Legislativo ou do Poder Executivo coacto ou impedido, ou de requisição do Supremo Tribunal Federal, se a coação for exercida contra o Poder Judiciário;

II - no caso de desobediência a ordem ou decisão judiciária, de requisição do Supremo Tribunal Federal, do Superior Tribunal de Justiça ou do Tribunal Superior Eleitoral;

III de provimento, pelo Supremo Tribunal Federal, de representação do Procurador-Geral da República, na hipótese do art. 34, VII, e no caso de recusa à execução de lei federal.

$\S 1^{\circ} \mathrm{O}$ decreto de intervenção, que especificará a amplitude, o prazo e as condições de execução e que, se couber, nomeará o interventor, será submetido à apreciação do Congresso Nacional ou da Assembleia Legislativa do Estado, no prazo de vinte e quatro horas.

$\S 2^{\circ}$ Se não estiver funcionando o Congresso Nacional ou a Assembleia Legislativa, far-se-á convocação extraordinária, no mesmo prazo de vinte e quatro horas.

$\S 3^{\circ}$ Nos casos do art. 34, VI e VII, ou do art. 35, IV, dispensada a apreciação pelo Congresso Nacional ou pela Assembleia Legislativa, o decreto limitar-se-á a suspender a execução do ato impugnado, se essa medida bastar ao restabelecimento da normalidade.

$\S 44^{\circ}$ Cessados os motivos da intervenção, as autoridades afastadas de seus cargos a estes voltarão, salvo impedimento legal's2.

XXXII O STF entendeu que a regra de reserva de iniciativa de lei é importante aspecto no desenho da tripartição dos poderes, de sorte que os estados-membros a ele se vinculam ${ }^{83}$. 
É importante ressalvar que as regras de simetria só se circunscrevem as categorias fundamentais de organização da Carta Magna ou do chamado fulcro constitucionais estabelecidas aos entes federados.

Enfim, as regras condicionantes do Poder Constituinte Decorrente aplicam-se não só a legislação estadual como à municipal, e nestes termos é que deve ser compreendida a ressalva contida no caput do art. 25 da CF/88XXXIII, cuja síntese do acima exposto é resumido por Tércio Sampaio Ferraz Junior ${ }^{51}$ :

Os princípios fundamentais originários, instituídos, de reconhecimento e teleológicos constituem o núcleo sensível da Constituição Federal de tal modo que a constituinte estadual neles encontra a condição fundamental de sua principialidade decorrente. Neste sentido, eles são intocáveis, pois alterá-los é colocar-se como constituinte originário (...). A Constituição, porém, ao instituir o princípio federativo, já delineia a federação, estabelecendo-lhe certos princípios comuns de organização (...). Dentre eles mencionem-se os constantes do art. 37, referentes à Administração Pública dos quatros entes políticos da Federação e comuns a eles. São eles o princípio da legalidade, impessoalidade, moralidade e publicidade (que são, aliás, seguidos de regras comuns a todos eles). Aqui se incluem (...) plano de carreira dos servidores, (...), o princípio da proporcionalidade eleitoral (art. $45 \mathrm{c} / \mathrm{c}$ art. 27 e aart. 29, IV), os do art. 93 referentes a magistratura, os do art. 145, $1^{\circ}$ (pessoalidade $\mathrm{e}$ gradualidade, conforme a capacidade contributiva, dos tributos [sic]), os do art.150 (anterioridade na estatuição dos tributos) e ainda os do art. 170 (Ordem econômica).

(...) Ora, a aceitarem-se estes comentários, devemos fazer notar que, quando a Constituição Federal fala em "observados os princípios desta Constituição", referindo-se ao constituinte estadual, reportar-se genericamente a princípios e regras, sem maiores distinções. (...) Com respeito às regras devemos reconhecer, ademais, que nem todas contêm vedações expressas. Assim, p. ex. o art. 19 contém regras que vedam à União, Estados, Distrito Federal e Municípios expressamente, certos comportamentos normativos (p. ex., recusar fé a documentos públicos, criar distinções entre brasileiros ou de preferências entre si etc.). Outras disciplinam a competência legislativa comum, concorrente e suplementar (art. 22, parágrafo único, arts. 23 e 24). Os parágrafos $1^{\circ}$ a $4^{\circ}$ do art. 24 contêm regras para a disciplina das competências suplementar e concorrente. A distribuição de competências, por meio de regras, contém, porém, a contrário sensu, vedações para o constituinte estadual. Em outros casos ainda, a Constituição federal estende, compulsoriamente, aos Estados certas regras, como é o caso do art. 27, § 1, em que se manda aplicar as regras desta Constituição

XXXIII "Art. 25. Os Estados organizam-se e regem-se pelas Constituições e leis que adotarem, observados os princípios desta Constituição.

$\S 1$ - São reservadas aos Estados as competências que não thes sejam vedadas por esta Constituição.

$\S 2^{\circ}$ Cabe aos Estados explorar diretamente, ou mediante concessão, os serviços locais de gás canalizado, na forma da lei, vedada a edição de medida provisória para a sua regulamentação.

$\S 3^{o}$ Os Estados poderão, mediante lei complementar, instituir regiões metropolitanas, aglomerações urbanas e microrregiões, constituídas por agrupamentos de municípios limítrofes, para integrar a organização, o planejamento e a execução de funções públicas de interesse comum, 82 . 
sobre o sistema eleitoral, inviolabilidade, imunidades, remuneração, perda de mandato, licença, impedimentos e incorporação às Forças Armadas.

Dessa forma, refere-se aos deputados estaduais, intromissão direta aos limites de organização dos Poderes do estado-membro, em detrimento da autonomia desses, mas prestigiada em prol de um amálgama organizacional mínimo à federação, bem como para correção de assimetrias de fato, inclusive culturais, de estados descompromissados com os gastos e atividades públicas.

A observância desses comandos deve ser entendida como a necessidade de se legislar através e parâmetros compatíveis que concretizem os citados preceitos, sob pena de se incorrer em inconstitucionalidade, ou até mesmo intervenção federal, nas hipóteses contidas no art. 34 da CF/88.

Sopesados esses condicionamentos de natureza constitucional, 0 campo legislativo estadual é de natureza remanescente, conforme reza o art. 25, $\S 1^{\circ}$ da Carta Magna, fórmula do federalismo clássico, deveras abrandado pela riqueza integradora da CF/88 e seus preceitos de pré ordenação institucional, a qual aguça alguns constitucionalistas a afirmar que os estados se encontram arquitetar leis que transcendem essa suposta limitação constitucional dos estados membros.

Emerge daí a assertiva que limitações à autonomia estadual através de princípios implícitos não corresponde aos valores da Carta Magna, diante dos princípios e regras explícitas nesse sentido ${ }^{57}$.

Exemplo dessa discussão é a não utilização das regras gerais para controle dos rejeitos radioativos ao meio ambiente, pois limitaria a instalação de usinas nucleares em determinado estado, Distrito Federal ${ }^{\mathrm{XXXV}}$ ou território.

XXXIV É de se destacar que o Distrito Federal, Brasília como a sede da capital da república e assume papel de ente federado próprio, goza de peculiaridade ímpar, pois acumula as competências próprias de um estado-membro, bem como as municipais. Como ensina José Afonso da Silva ${ }^{33}$, o Distrito Federal surgiu da transformação do antigo Município neutro, que era a sede da corte e capital do Império. Não é estado. Não é município. Contudo, congrega simultaneamente as competências legislativas e tributárias desses últimos. Sua origem tem, portanto, conotação de resguardo da soberania nacional, pois visa melhor localização operacional e geopolítica da Capital federal, sede da Federação.

A Carta Magna elevou, pois, o Distrito Federal à condição do ente federativo (ente autônomo nos termos e limites constitucionais). Dispôs expressamente que ao Distrito Federal são atribuídas as competências legislativas reservadas aos estados e municípios (arts. 32, $\S 1^{\circ}$ e $147 \mathrm{da} C F / 88$ ). Contudo, reservou a união a tutela e a legislação sobre organização judiciária, do Ministério Público e da Defensoria Pública, bem como da polícia civil, militar e do corpo de bombeiros militar, todos mantidos e organizados pela união, cuja utilização desses últimos é regrada por lei federal. Daí a conotação de que o Distrito Federal é tutelado pela União sob alguns aspectos. 
Além disso, o Supremo Tribunal Federal já decidiu que a responsabilidade civil pelos danos radiológicos causados por rejeitos armazenados em depósito provisório decorrente de falha na segurança física é do estado, o que permite que este crie regras específicas sobre o tema.

Contudo, as referidas regras deverão seguir os mesmos moldes expressos na $\mathrm{CF} / 88$, isto é, deverão respeitar a hierarquia das normas e a separação dos poderes.

Realmente, a separação de poderes é forma de divisão horizontal de competências para o fim de melhor garantir a excelência do uso do poder, fiel as lições de Montesquieu, que delineou a visão tripartite do estado, cuja lógica é extensível aos demais entes federados.

\subsubsection{A competência legislativa e privativa dos Municípios}

O federalismo brasileiro tem como originalidade a inclusão dos Municípios como componentes federados na República Federativa do Brasil, frisado já na abertura da Carta Magna no art. 1ํㅜ, que determina a união indissolúvel dos estados e municípios e do Distrito Federal, constituindo um único

Cabe, pois, ao Distrito Federal as competências remanescentes que são reservadas aos estados, firmadas no art. $25, \S 2^{\circ}$, bem como as competências locais atribuídas então aos municípios, já que ao distrito Federal é vedado dividir-se em municípios. Goza, portanto, o Distrito Federal de autonomia politico-constitucional expressa na própria Constituição da República Federativa do Brasil de 1988, princípio estruturante de sua organização institucional e da federação brasileira, qualificando-se como prerrogativa política, de sorte que somente no âmbito da Carta Magna terse-á aos limites de sua autonomia, tal como desenhada.

Sua auto-organização é firmada através da Lei Orgânica, aprovada pela câmara legislativa, atendidos aos princípios da CF/88, com plena similitude para a eleição de seu Governador, vicegovernador e Deputados Distritais.

Nos termos de sua Lei Orgânica, em cortejo com a CF/88, Brasília é ao mesmo tempo Capital da Federação é também sede do governo do Distrito federal. Neste contexto, não se vislumbra a possibilidade de criação no Distrito Federal de regiões metropolitanas, microrregiões e aglomerações urbanas, pois ausente fundamento constitucional para tanto, diante do preceito constitucional que veda sua divisão em municípios, logo não há que se falar juridicamente em regiões metropolitanas no âmbito do Distrito Federal.

Dada a acumulação das atribuições administrativas e prerrogativas legislativas próprias dos estados e dos municípios sobre a égide do Distrito federal, sua interação legislativa se faz tão somente com as normas federais, seja no âmbito da competência privativa ou concorrente, entre essas a legislação referente ao seu Poder Judiciário, ao ministério Público, Defensoria Pública, polícia civil e militar e do corpo de bombeiros, pois todos são organizados e mantidos pela União Federal (art. 21, XIII e art 32, § $4^{\circ}$ da CF/88). Nesse sentido, menores as chances de conflitos de normas entre tais entes federados.

Assim, salvo quanto as exceções supra apontadas, a mesma lógica apresentada para a interpretação das normas estaduais e municipais aplica-se para a interpretação das normas distritais. 
Estado de Direito. O disposto no art. $18^{\mathrm{XXX}}$ do referido diploma legal reforça o status federado do município ao tratar da Organização do Estado, determinando que a organização político-administrativa do Brasil compreende os supracitados entes, todos autônomos.

Ressalva-se que já é antiga a tradição brasileira quanto ao reconhecimento da autonomia administrativa aos municípios, pois desde a primeira Carte Republicana concedeu-se a autonomia aos municípios na regência dos interesses locais, tal como estabelece $\mathrm{o}$ art. 68 da Carta de $1891^{\mathrm{XXXVI}}$. Neste contexto, alguns doutrinadores endossam a afirmação de que a Federação Brasileira desenvolveu-se em três planos, nela se identificando não a tradicional divisão entre ordem central, a ordem estadual/regional e a ordem municipal nominado por Charles Durand ${ }^{52}$ como federalismo de duplo grau, pois com dois círculos de autonomia, uma do estado-membro e outra do ente local.

Dessa posição singular do Município brasileiro é que resulta a sua autonomia politico-administrativa, diversamente do que ocorre nas demais Federações, em que o Município é circunscrição territorial meramente administrativa.

Assim, a própria lei Fundamental pôs fim ao debate que então reinava na doutrina sobre a natureza jurídica dos Municípios, porquanto restou expresso que esses integrantes da própria Federação, peculiaridade impar do Estado brasileiro.

O município é, portanto, pessoa jurídica de direito público interno, dotado de autonomia politica e administrativa, organizada através da Lei Orgânica do Município, diploma que dita os fundamentos e princípios diretrizes do modelo da organização municipal visada pelo munícipe, elaborada pela própria Câmara Municipal $^{\mathrm{Xx} X \mathrm{~V} I \mathrm{l}}$ é o que enfatiza a autonomia politica do ente federado.

Tal como a autonomia estadual, também a municipal é condicionada pelos princípios constitucionais nacionais e estaduais, conforme frisa o artigo 29

$\overline{x x x v}$ Art. 18. A organização político-administrativa da República Federativa do Brasil compreende a União, os Estados, o Distrito Federal e os Municípios, todos autônomos, nos termos desta Constituição.

xxxVI Art. 86. Os estados organizar-se-ão de forma que fique assegurada a autonomia dos municípios em tudo quanto respeite ao seu peculiar interesse.

XXXVII Evolução da Carta de 1988, pois outrora tal competência era dos Estados. 
da CF/88. Nem poderia ser diferente, pois só assim se preserva o mínimo de unidade nacional e a própria integração das unidades federadas. A autonomia municipal é firmada pela sua Lei Orgânica, cujos limites são justamente a observância dos princípios basilares do sistema nacional e estadual.

Carmen Lúcia Antunes Rocha ${ }^{53}$ aponta com propriedade a extensão e os limites da Lei Orgânica Municipal:

\begin{abstract}
O munícipe tem sua condição afirmada, definitivamente, na Lei Orgânica Municipal, onde a Democracia pode ter formas de exercício que modificam substancialmente as instituições. Por isso a Lei Orgânica tem sido considerada "verdadeiro código dos munícipes" por alguns ou uma "Minilei Fundamental" por outros. É que nela se traçam os instrumentos da ação do cidadão em sua localidade e o poder é controlado e tem sua forma de exercício definida, em última instância, segundo as normas ali afirmadas. Poder-se-ia asseverar que o imperioso acatamento dos princípios constitucionais nacionais ou estaduais tolheria o legislador municipal impedindo criações significativas nesse plano. Não é isso exatamente verdade, quando se leva em conta os princípios limitadores, materialmente, do legislador municipal são aqueles que se referem à Democracia, à República, á participação popular, enfim, princípios que podem ser aplicados e exercidos de variadas formas, o que permite um raio de ação do legislador bastante interessante.
\end{abstract}

Como se vê, a Constituição amolda preceitos a serem pormenorizados pela Lei Orgânica Municipal, segundo as diretrizes da Carta Magna, como se a eletividade do Prefeito, Vice-Prefeito e dos Vereadores, seus respectivos mandatos de quatro anos, mediante pleito direto e simultâneo realizado em todo o país.

Já a definição do numero de vereadores é diretamente proporcional $^{X X X V I I I}$ à população do Município, em sintonia com o modelo adotado para a Câmara dos Deputados e Assembleia Legislativa, consoante determina a Resolução de nº 1.702/04 do Tribunal Superior Eleitoral, editada após o julgamento do Recurso Extraordinário nº 197.917 pelo Supremo Tribunal Federal

xxxVIII Interessante polêmica firmou-se no STF a respeito do desdobramento do princípio da proporcionalidade sobre a composição do número de vereadores na Câmara Municipal, porquanto matematicamente exige-se 47.619 habitantes no município para se ter um vereador a mais que o mínimo constitucional, segundo o regramento constitucional do art.29, IV. Essa é a orientação do julgamento por maioria do Recurso Extraordinário 197.917 que contestou a representação legislativa no município de Mira Estrela, da necessidade de se adotar a fórmula de proporcionalidade de um vereador para cada 47.619 habitantes. Mira Estrela, tendo menos de três mil habitantes, se enquadraria no limite mínimo constitucional de nove vereadores. O Recurso Extraordinário foi movido pelo Ministério Público estadual do estado de São Paulo contra o parágrafo único do art. 6을 da Lei Orgânica ํo. 226/90 no município paulista, que fixou em onze, o número de parlamentares da Câmara de Vereadores, acima, portanto, do critério matemático ora adotado no Acórdão. 
que reconheceu a inconstitucionalidade incidenter tantum ${ }^{X X X X}$ com efeitos ex nunc $^{X L}$ da norma municipal que fixou o número de vereadores em patamar desproporcional ao entabulado na Constituição da República Federativa do Brasil de 1988; fixou-se interpretação de cogente proporcionalidade entre o número de habitantes e o de vereadores, em homenagem ao princípio da força normativa da CF/88, corroborado aos postulados da moralidade, impessoalidade e economicidade.

Em período anterior à querela supracitada, o Supremo Tribunal Federal afastou a possibilidade da Carta Magna fixar o número de vereadores, ao expurgar dispositivo da Constituição de Tocantins que fixava a proporcionalidade do número de Vereadores diretamente na Constituição Estadual ${ }^{\mathrm{XLI}}$, tarefa da Lei Orgânica Municipal, mas fiel ao modelo constitucional.

O constituinte sumarizou a competência dos Municípios no art. 30 da $\mathrm{CF} / 88^{\mathrm{XLII}}$, embora haja atribuições esparsas no corpo da CF/88 referente aos Municípios. Sustenta a competência legislativa privativa ou exclusiva no inciso I.

XxxIX Incidenter tantum é expressão derivada do Latim que traduz algo que é objeto de questionamento ou decisão, por exemplo, em processo judicial, mas não identifica o mérito da causa, sendo decidido de maneira apenas incidente. Em outras palavras, Incidenter tantum, assim, quer significar: "de maneira incidente", não como o objeto principal da lide. É a superveniência de fato ou de questão, que ocorre quando se trata de outro fato ou questão de que se mostra acessório, e esta, principal. $\mathrm{Na}$ técnica forense, em referência às questões incidentemente surgidas no curso do processo, a que se deva dar merecida atenção, dizem-se processos incidentes, causas incidentes ou meras questões incidentais. A falsidade, a habilitação de herdeiros, ocorridas na causa, são incidentes dela ${ }^{84}$.

${ }^{\mathrm{XL}}$ Ex nunc - expressão de origem latina que significa "desde agora". Assim, no meio jurídico, quando dizemos que algo tem efeito "ex nunc", significa que seus efeitos não retroagem, valendo somente a partir da data da decisão tomada.

${ }^{\mathrm{XLI}}$ BRASIL, Supremo Tribunal Federal. Ação Direita de Inconstitucionalidade no. $1.038^{85}$.

XLII Art. 30. Compete aos Municípios:

I - legislar sobre assuntos de interesse local;

II - suplementar a legislação federal e a estadual no que couber;

III - instituir e arrecadar os tributos de sua competência, bem como aplicar suas rendas, sem prejuízo da obrigatoriedade de prestar contas e publicar balancetes nos prazos fixados em lei;

IV - criar, organizar e suprimir distritos, observada a legislação estadual;

$\mathrm{V}$ - organizar e prestar, diretamente ou sob regime de concessão ou permissão, os serviços públicos de interesse local, incluído o de transporte coletivo, que tem caráter essencial;

VI - manter, com a cooperação técnica e financeira da União e do Estado, programas de educação infantil e de ensino fundamental; VII - prestar, com a cooperação técnica e financeira da União e do Estado, serviços de atendimento à saúde da população;

VIII - promover, no que couber, adequado ordenamento territorial, mediante planejamento e controle do uso, do parcelamento e da ocupação do solo urbano;

IX - promover a proteção do patrimônio histórico-cultural local, observada a legislação e a ação fiscalizadora federal e estadual. 
Ampara ainda, a competência concorrente no inciso II; a competência legislativa implícita/indireta, advinda da competência administrativa expressa nos demais incisos do mencionado artigo, sob a batuta do princípio da legalidade que preside os atos administrativos e clama pela aludida competência legislativa implícita, cuja tônica deve ser sempre visar o interesse local - fugiu, assim, o constituinte da técnica de separar por artigos a competência administrativa da legislativa.

O traço marcante da delimitação constitucional para aferir a legislação municipal é justamente a referência a assuntos de interesse local, conforme preconiza o art. 30, inc. I, da CF/88, eis a cláusula-chave para perquirir a legitimidade do Município para legislar sobre os mais variados assuntos.

Nesses termos, tem-se que a mesma lógica que presidiu 0 entendimento da legitimidade da legislação municipal, sob a égide das Constituições anteriores, desde 1891, que previa a expressão "peculiar interesse" preside o entendimento atual. Como sustenta Fernanda Dias Menezes de Almeida “(...) a mudança da letra não equivale a uma mudança do espírito da Constituição" 59 .

\subsubsection{Competência legislativa concorrente dos entes federados: aspectos gerais}

Inicialmente é importante ressaltar que a Carta Magna de 1988 abordou todas as experiências constitucionais pretéritas nas técnicas de partilha de competências, ao implantar divisão de competências tanto na horizontal ou privativa como na vertical ou concorrente. Daí o sentido do nome competência concorrente, pois sobre a mesma matéria concorre mais de um ente político, tanto na competência administrativa (art. 23 da CF/88 ${ }^{\mathrm{XLIII}}$ ) como na seara legislativa

\footnotetext{
XLIII Art. 23. É competência comum da União, dos Estados, do Distrito Federal e dos Municípios: I - zelar pela guarda da Constituição, das leis e das instituições democráticas e conservar o patrimônio público;

II - cuidar da saúde e assistência pública, da proteção e garantia das pessoas portadoras de deficiência;

III - proteger os documentos, as obras e outros bens de valor histórico, artístico e cultural, os monumentos, as paisagens naturais notáveis e os sítios arqueológicos;

IV - impedir a evasão, a destruição e a descaracterização de obras de arte e de outros bens de valor histórico, artístico ou cultural;

$\mathrm{V}$ - proporcionar os meios de acesso à cultura, à educação, à ciência, à tecnologia, à pesquisa e à inovação;

VI - proteger o meio ambiente e combater a poluição em qualquer de suas formas;
} 
(art. 24 da CF/88 ${ }^{\mathrm{XLIV}}$ ), que consagra os assuntos de interesse recíproco de todos os entes federados.

A competência concorrente constitui apurada técnica do federalismo de equilíbrio, diante da parceria de ação e responsabilidade que se estabelece entre os entes federados para a consecução de objetos comuns e do regramento conjunto dos assuntos que extravasam o interesse de um único ente político. Cuida-se, pois, de mecanismo de descentralização política e de encargos administrativos, dada a peculiaridades, rumo a um progresso conjunto e planejado de toda a nação.

VII - preservar as florestas, a fauna e a flora;

VIII - fomentar a produção agropecuária e organizar o abastecimento alimentar;

IX - promover programas de construção de moradias e a melhoria das condições habitacionais e de saneamento básico;

$\mathrm{X}$ - combater as causas da pobreza e os fatores de marginalização, promovendo a integração social dos setores desfavorecidos;

$\mathrm{XI}$ - registrar, acompanhar e fiscalizar as concessões de Direitos de pesquisa e exploração de recursos hídricos e minerais em seus territórios;

XII - estabelecer e implantar política de educação para a segurança do trânsito.

Parágrafo único. Leis complementares fixarão normas para a cooperação entre a União e os Estados, o Distrito Federal e os Municípios, tendo em vista o equilíbrio do desenvolvimento e do bem-estar em âmbito nacional.

XLIV Art. 24. Compete à União, aos Estados e ao Distrito Federal legislar concorrentemente sobre:

I - Direito tributário, financeiro, penitenciário, econômico e urbanístico;

II - orçamento;

III - juntas comerciais;

IV - custas dos serviços forenses;

$\mathrm{V}$ - produção e consumo;

VI - florestas, caça, pesca, fauna, conservação da natureza, defesa do solo e dos recursos naturais, proteção do meio ambiente e controle da poluição;

VII - proteção ao patrimônio histórico, cultural, artístico, turístico e paisagístico;

VIII - responsabilidade por dano ao meio ambiente, ao consumidor, a bens e Direitos de valor artístico, estético, histórico, turístico e paisagístico;

IX - educação, cultura, ensino, desporto, ciência, tecnologia, pesquisa, desenvolvimento e inovação;

$X$ - criação, funcionamento e processo do juizado de pequenas causas;

$\mathrm{XI}$ - procedimentos em matéria processual;

XII - previdência social, proteção e defesa da saúde;

XIII - assistência jurídica e Defensoria pública;

XIV - proteção e integração social das pessoas portadoras de deficiência;

$X V$ - proteção à infância e à juventude;

$X V I$ - organização, garantias, Direitos e deveres das polícias civis.

$\S 1^{\circ}$ No âmbito da legislação concorrente, a competência da União limitar-se-á a estabelecer normas gerais.

$\S 2^{\circ}$ A competência da União para legislar sobre normas gerais não exclui a competência suplementar dos Estados.

$\S 3^{\circ}$ Inexistindo lei federal sobre normas gerais, os Estados exercerão a competência legislativa plena, para atender a suas peculiaridades.

$\S 4^{\circ}$ A superveniência de lei federal sobre normas gerais suspende a eficácia da lei estadual, no que lhe for contrário. 
Das complexas relações de interdependência entre União e os entes federados, no federalismo cooperativo, emergem a coordenação e a cooperação, sendo que a primeira é a própria das competências concorrentes, ao passo que a segunda advém das competências materiais comuns.

A coordenação é, na realidade, um modo de atribuição e exercício
conjunto de competências no qual os vários integrantes da Federação
possuem certo grau de participação. A vontade das partes é livre e igual,
com a manutenção integral de suas competências: os entes federados
sempre podem atuar de maneira isolada ou autônoma. A coordenação é
um procedimento que busca um resultado comum e do interesse de
todos. A decisão comum, tomada em escala federal, é adaptada e
executada autonomamente por cada ente federado, adaptando-se às
suas peculiaridades e necessidades. A União e os entes federados
concorrem em uma mesma função, mas com âmbito e intensidade
distintos. Cada parte decide, dentro de sua esfera de poderes, de
maneira separada e independente, com a ressalva da prevalência do
Direito federal. Este tipo de repartição é o previsto pelo art. 24 da
Constituição de $1988^{54}$.

A técnica da competência concorrente trabalha, portanto, tanto no âmbito nacional de planejamento legislativo, ditadas pelas normas gerais da União, como no âmbito estadual. Através das normas estaduais que suplementam a legislação nacional de acordo com as necessidades peculiares do estado membro e dos interesses marcantes de sua economia em sintonia com o federalismo, a unidade nacional por meio da diversidade regional.

Congrega-se, pois, as forças de duas ordens: a de centralização de um lado e a descentralização do outro; ou melhor, as normas gerais que disciplinam uniformidade à Federação em matéria comum, através das normas da União, e normas complementares dos estados membros que modulam as suas peculiaridades locais.

Fernanda Dias Menezes de Almeida $^{59}$ observa a importância da presente técnica. Em tema de repartição de competências pode-se dizer que o mais marca a Carta Magna de 1988 é a acentuada exploração das potencialidades da competência legislativa concorrente, na tentativa de se dar maior peso às ordens parciais no relacionamento federativo.

Primeiramente, o constituinte cuidou da competência administrativa comum, atribuindo a todos os entes federados o ônus e consequente responsabilidade de zelar por assuntos de acentuado interesse públicos, conforme se interfere nos doze incisos do art. 23 da $\mathrm{CF} / 88$, dos quais merece ênfase 0 meio ambiente. A cooperação e o regime de atuação dos entes 
federados no tema administrativo será orquestrada por meio de leis complementares federais de eficácia nacional, tendo em vista o equilíbrio de desenvolvimento e o bem estar nacional, consoante dispõe o art. 23, paragrafo único da Carta Magna de 1988. Logo, caberá ao ente central ditar o regime de execução das áreas de competência comum. Enquanto ausente tal normativa, cada ente federativo é autônomo parar expressar-se a sua conveniência e interesse, mas sempre visando o bem estar nacional (art. 3ํㅡ. Il da CF/88).

A execução de tarefas administrativas pelos entes federados dá ensejo à competência legislativa indireta e concorrente para explicitação dos necessários comandos legislativos em consonância com o princípio da estrita legalidade, conforme Anna Cândida Ferraz ${ }^{56}$ :

As atividades a serem exercidas no campo material das competências
comuns somente poderão ser executadas, na generalidade dos casos,
fundamentadas em regulamentação normativa precedente, oriunda de
mais de um nível normativo de poder. Nesta hipótese, ocorrerá a
chamada repartição vertical de competências, o que significa dizer que
a atividade poderá ser exercida pelas diferentes esferas políticas. Porém
estará sujeita à disciplina legislativa hierarquizada e à regras gerais
impostas pelo poder central.

Interessante polêmica surgiu a respeito dos convênios entre os entes políticos, porquanto, via de regra, vige a prestação de serviços públicos de execução imediata para as competências materiais privativas, em que cada esfera executa os respectivos serviços pelo próprio corpo de funcionários, mas se sustenta que, ainda nessa seara, quando presentes razões de política administrativa, admite-se sim o concurso de outras esferas na execução de tarefa própria de outro ente federado, ou mesmo a combinação de esforços para a consecução do bem comum mediante convênios, entre os quais pode-se citar os convênios mantidos entre a Agência Nacional de Petróleo e as Secretarias Estaduais para a fiscalização de postos de combustíveis.

Quer em face de uma interpretação evolutiva do tema no âmbito constitucional, tanto porque a Constituição anterior expressamente admitia essa concepção, quer em razão do rumo progressivo da prestação de serviços públicos que alberga na sua trajetória tantas outras formas associativas como desenha a história do instituto, não há razão para o impedimento de consórcios desse gênero entre os entes federados. 
Necessária, contudo, a estipulação prévia e acertada do convênio, ditada pela liberdade de ingresso e saída dos integrantes, bem como a coordenação do serviço pelo titular da competência, o que constitui típico mecanismo de equilíbrio e coordenação de atribuições no modelo federalista adotado pelo Brasil. Desse modo, não há inconstitucionalidade em tais convênios, nem mesmo a necessidade de sua estipulação via Lei Complementar, ainda que celebrados para o tema das competências administrativas privativas. Nesse sentido é a redação do art. $24, \S 1^{\circ}$ da CF/88 que autoriza a gestão associada de serviços públicos entre os entes federados. Relevante, ainda,

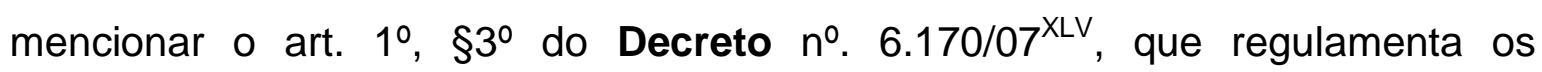
convênios e contratos de repasse da União.

\subsubsection{Competências administrativas comuns de todos os entes federados}

Inicialmente é importante se observar que o federalismo cooperativo funda-se na cooperação mútua dos entes federados para melhor desempenho das tarefas de interesse comum, conforme orientação do Poder Central, através do entrelaçamento e interdependência entre os níveis de governo em prol dos interesse do cidadão e do equilíbrio de forças da Federação Este é a principal característica das competências administrativas comuns entre os três entes da Federação brasileira, conforme 0 art. 23 da Constituição da República Federativa do Brasil de 1988.

Dessa forma, o Poder Público cumpre funções de forma vertical, cabendo a União definir as linhas de desenvolvimento nacional e, horizontal, cabendo simultaneamente aos entes federados a definição, entre si, dos instrumentos operacionais, por meio dos quais implementarão as tarefas comuns.

O principal elemento das competências administrativas comuns é justamente a diretriz do federalismo cooperativo, a cooperação entre os entes

\footnotetext{
XLV Art. 1을 Este Decreto regulamenta os convênios, contratos de repasse e termos de execução descentralizada celebrados pelos órgãos e entidades da administração pública federal com órgãos ou entidades públicas ou privadas sem fins lucrativos, para a execução de programas, projetos e atividades que envolvam a transferência de recursos ou a descentralização de créditos oriundos dos Orçamentos Fiscal e da Seguridade Social da União.

(...)

$\S 3^{\circ}$ Excepcionalmente, os órgãos e entidades federais poderão executar programas estaduais ou municipais, e os órgãos da administração direta, programas a cargo de entidade da administração indireta, sob regime de mútua cooperação mediante convênio.
} 
federados para o desempenho racional de atividades de responsabilidade comum. E para operacionalização dos serviços conjuntos aos entes federados é necessário traçar políticas mínimas para a definição conjunta do planejamento para a promoção do desenvolvimento nacional.

Diante da ausência da positivação da lei complementar estipulada no art. 23, paragrafo único da $\mathrm{CF} / 88$, os entes federados deverão por si, através da política articulada, delineada em acordos, efetivar o desenvolvimento das tarefas de atribuição comum, baseado no planejamento e na colaboração recíproca.

Essa é a orientação que vige no momento, até porque a alteração da redação do citado artigo de lei determinou que leis complementares fixassem normas para cooperação entre os entes federados, tendo em vista o equilíbrio do desenvolvimento e do bem estar no âmbito nacional. Vê-se, portanto, as múltiplas leis complementares, todas provindas da União, em diferentes campos na área administrativa. Contudo, as mencionadas leis ainda não foram positivadas.

Nota-se, entretanto, que no decorrer das atividades comuns aos entes federados há certa coesão em relação as competências concorrentes, como por exemplo, a proteção ao meio ambiente e a preservação da fauna e flora (art. 23, VI e VII da CF/88).

Assim, no caso de conflito legislativo entre essas matérias, deve-se seguir o norte dos apontamentos próprios à competência legislativa concorrente, pois a coordenação esta para as competências legislativas concorrentes, assim como a cooperação esta para as competências comuns. Logo, nas competências comuns, todos os entes da Federação devem colaborar para a execução das tarefas colaborar para a execução das tarefas determinadas na Carta Magna, uma vez que não existindo supremacia de nenhuma das esferas na execução destas tarefas, as responsabilidades também são comuns não podendo nenhum dos entes da Federação se eximir de implementá-las.

Ressalva-se, assim, a cooperação como elemento nuclear aos entes federados no âmbito das competências administrativas comuns, pois busca resultados unitários e uniformizadores sem esvaziar os poderes e competências dos entes federados em relação à União. A cooperação parte do pressuposto da estreita interdependência que existe em inúmeras matérias e programas de interesse comum. Todos os entes federados devem colaborar para a execução destas tarefas. 
Dessa forma, têm-se fielmente as diretrizes do federalismo cooperativo, a autonomia político administrativa dos entes federados não enfraquece ou compromete a atuação entre os entes. 


\section{DESENVOLVIMENTO DO TRABALHO}

\subsection{Competências materiais ou legislativas decorrentes no Direito Nuclear}

Algumas linhas sobre as competências materiais dos entes federados serão apontadas, especialmente sobre as atribuições administrativas conferidas na Constituição da República Federativa do Brasil de 1988 aos entes políticos para que esses desempenhem ou garantam o exercício de determinadas atividades detendo a titularidade do serviço e a responsabilidade para 0 desempenho de estas funções, que ora realizam por si só, ora delegam a iniciativa privada mediante a concessão ou permissão.

A referida legislação arrola tarefas a serem zeladas pelo ente federativo, através de condutas administrativas de coordenação, planejamento, fiscalização e fomento, para enfim garantir que determinadas atividades sejam efetivas sob o controle da União, dos estados ou dos municípios;

Floriano Azevedo Marques ${ }^{55}$ pontua que estas atividades estão insertas no campo próprio da regulação estatal realizada pelos federados, segundo a qual esses, por meio de intervenção estatal direta ou indireta, condicionam, normatizam ou incentivam a atividade econômica de modo a preservar a sua existência, assegurar seu equilíbrio ou atingir determinados objetivos com a política pública.

Destas obrigações materiais advêm as chamadas competências legislativas impróprias ou decorrentes, as quais surgem por via da competência administrativa, da necessidade de regular os interesses que the são deferidos constitucionalmente.

Luiz Alberto David Araújo ${ }^{56}$ complementa referida assertiva ao observar que das competências comuns (art. 23 da CF/88) surgem as chamada 
competências decorrentes impróprias, pois estas têm lugar ante a necessidade de se dar alicerce legislativo para o exercício de uma competência comum, como por exemplo, a determinação de proteger o meio ambiente (art. 23, VI). Pondera, ainda, que as competências legislativas impróprias não têm no seu regime jurídico limites, ou seja, cada ordem federativa pode legislar de maneira integral sobre a matéria. A situação regulamentada, por sua vez, ficará submetida ao espectro regrativo das leis de todas as ordens da federação.

Assim, diante destes imperativos materiais impostos aos entes federados, decorre a prerrogativa legislativa para regular suas atribuições, direitos e obrigações justamente para consecução de seus objetivos. Decorre, assim, a possibilidade da insurgência de conflitos legislativos dada a multiplicidade de centros normativos que interagem tanto em nível federal, estadual, como municipal em assuntos convergentes. Um exemplo disso é a competência material em relação à energia nuclear.

Paulo de Bessa Antunes $^{57}$, afirma que em relação a energia nuclear se trata de matéria constitucional de competência exclusiva da União e que não há a estreita relação existente com a proteção ambiental, pois seria, dessa forma, um direito eminentemente econômico. Insiste ainda na impossibilidade de confundir o direito ao meio ambiente com o direito nuclear, fazendo ligação apenas no que concerne ao dano nuclear e suas consequências ambientais.

Entretanto, ele próprio, aliado a outros consagrados doutrinadores, admite que questões envolvendo a energia nuclear tem grandes repercussões ambientais, o que motivou a inserção do tema no capítulo constitucional do meio ambiente.

Certo é, que a energia nuclear foi tratada de forma particular pelo legislador constituinte, o que acarreta a observância de suas regras próprias em detrimento de regras gerais, observando-se, assim, o princípio da especialidade para interpretação dos dispositivos normativos. E uma destas regras específicas encontra-se na análise da competência legislativa, tratando-se, pois, de competência privativa da União, significando a sua indelegabilidade.

Como coadunar, então, esta regra com as regras de competência estabelecidas quanto ao meio ambiente? A questão não é simples de ser respondida, tampouco pacífico é o seu entendimento. 
Para os aspectos relativos ao meio ambiente, as regras permitem a delegação de competência, inclusive com casos de competência concorrente entre União, estados e Municípios, principalmente quando o assunto se refere à poluição, sendo possível a intervenção das três esferas para que se impeça a proliferação de um mal.

A CF/88, por sua vez, estabeleceu de forma expressa que todo o controle acerca do assunto referente a atividades nucleares deve ser exercido pela União, por causa da importância existente e da variedade de riscos que devem ser drasticamente controlados e observados, razão pela qual impede que ocorra qualquer abertura para o setor privado, onde o estado perderia o controle absoluto, necessário em se tratando de riscos nucleares que, se não monitorados com extremo rigor, podem atingir grande parte da população.

Contudo, estas regras gerais não são utilizadas para determinadas competências materiais, como é o caso, por exemplo, do controle da poluição, pois se assim fosse feito, estaria se impedindo a instalação de uma usina nuclear em determinado estado ou município. E não é isso que se verifica na sociedade.

Assim, neste caso há, como já afirmado anteriormente, a insurgência dos conflitos legislativos, com a elaboração de normas infraconstitucionais estaduais e municipais que dispõe sobre os meios de mitigação de eventual poluição, bem como restrições, mas nunca proibições taxativas.

Outro ponto a ser observado no que se refere à competência material no direito Nuclear, é o foro do local do possível dano ambiental causado, ou seja, visando regionalizar as melhores e imediatas soluções, possibilita a legislação que os danos e as responsabilidades sejam apresentados por aqueles que mais diretamente serão afetados pelo problema: os municípios. Mas aliado a esta regra, deve estar sedimentado o conceito da hierarquia das normas, permitindo sim que estados e municípios apresentem regramentos próprios para alguns aspectos relativos à atividade nuclear, como mencionado, desde que observados integralmente os princípios e as regras norteadoras dispostos na Constituição da República Federativa do Brasil de 1988.

Com isso, é possível que estados e municípios estabeleçam normas com a finalidade de que seja assegurada uma boa qualidade ambiental, já que os princípios fundamentais da República também devem ser observados, mas daí a admitir a inviabilização da atividade nuclear em alguns estados-Membros, seria 
desconsiderar a Política Nuclear hoje vigente no país, e que a duras penas conseguiu a posição atual, mesmo com tantas dificuldades ainda existentes.

\subsection{Competência em relação aos Rejeitos radioativos e a responsabilidade civil}

Inicialmente é importante observar que os rejeitos radioativos podem ser classificados como de baixa, média ou alta radiatividade, sendo que, no Brasil, apenas a Central Nuclear de Angra dos Reis produz rejeitos de alta radiatividade, relacionando-se com $\mathrm{o}$ alto risco à saúde, e, portanto, ao próprio meio

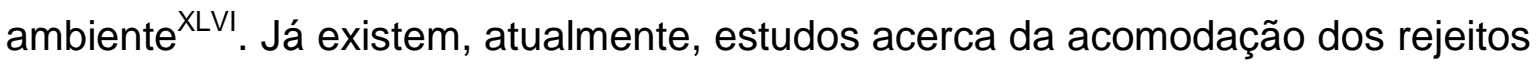
nucleares, como o condicionamento específico com vistas à estocagem, ou até ejeção espacial, que vêm gerando protestos de todos os gêneros e aumentando ainda mais as desconfianças e descrenças acerca dos programas nucleares.

No Brasil, a Lei ํo. $6.189 / 74^{58}$ dispõe sobre operações com materiais nucleares, tratamento e eliminação de rejeitos, mas há ausência de disciplina sobre escolha de localização para armazenamento dos resíduos eliminados, restando, dessa forma, aos estados e aos municípios definirem regras sobre o assunto. Um exemplo disso é a Constituição do Piauí que em seu artigo 241 estabelece que "não aceitará depósitos de resíduos nucleares produzidos em outras unidades da federação".

Outro exemplo a ser observado é a Constituição Estadual do Rio Grande do Norte em seu artigo 153, que dispõe: "Lei estadual, observada a

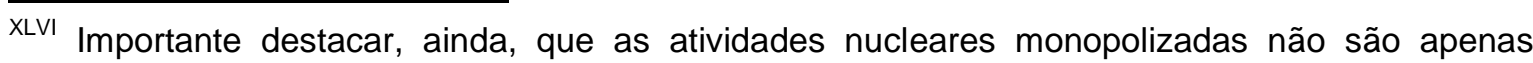
desenvolvidas em instalações nucleares, sendo a atividade de industrialização de minérios nucleares e derivados também executada em instalações radiativas, nas quais são produzidos os radioisótopos que são utilizados nas áreas médica, agrícola, industrial e em pesquisas.

Em relação às instalações nucleares, nem todas as atividades nelas desenvolvidas estão incluídas no regime monopolístico estatal, como por exemplo, a operação de usinas nucleoelétricas. É que a atividade desenvolvida nestas usinas, geração de energia elétrica, não se enquadra no rol de atividades monopolizadas pelo Estado, no setor nuclear, isto é, a pesquisa, a lavra, o enriquecimento e reprocessamento, a industrialização e o comércio de minérios nucleares e seus derivados.

Embora a usina nuclear seja uma instalação na qual há a utilização de material nuclear, trata-se de uma usina termelétrica, assim como a usina a carvão, que se distingue das demais pela utilização de combustível nuclear.

Dessa forma, trata-se de uma hipótese de atuação direta do Estado, no desenvolvimento de atividade econômica em sentido estrito, em concorrência com a iniciativa privada, atividade esta, atualmente desenvolvida pela Eletrobrás Termonuclear S/A, sociedade de economia mista especialmente constituída para essa finalidade, mas que também poderá ser executada por empresas concessionárias de energia elétrica, como previsto no art. 10 da Lei $n^{\circ}$ 6.189/74. 
limitação imposta por lei federal, disporá sobre o depósito temporário ou permanente de resíduos de material atômico de qualquer origem no território do estado".

Por fim, pode-se citar a Constituição de Goiás, que por sua vez, estado personagem principal do presente evento, impõe, pelo artigo 131, parágrafo $2^{\circ}$, a proibição de "Instalação de usinas nucleares, bem como a produção, armazenamento e transporte de armas nucleares de qualquer tipo (...)". E ainda pelo parágrafo 1 "resíduos radioativos, as embalagens de produtos tóxicos, o lixo hospitalar e os demais rejeitos perigosos deverão ter destino definido em lei, respeitados os critérios científicos".

Assim, conclui-se que os problemas maiores enfrentados pelo Brasil neste aspecto são aquele envolvendo uma cápsula com Césio 137 que ocasionou o acidente na cidade de Goiânia ${ }^{X L V I I}$, e ainda os rejeitos provenientes da usina

XLVII "A partir de setembro de 1987, o Brasil passou a integrar um restrito grupo de países que trazem em suas histórias um acidente envolvendo elementos radioativos; no caso brasileiro um acidente radiológico de tamanhas extensões e repercussões, que chega a ser comparado com os grandes acidentes nucleares já ocorridos.

Não nos cabe aqui questionar as circunstâncias que levaram ao fatídico acontecimento, sendo apenas relevante mencionar que a simplicidade e ignorância de uns e a total displicência de outros, culminaram com a contaminação de aproximadamente 250 pessoas.

Outro dado de relevante menção diz respeito ao número de vítimas, que passou extraordinariamente a quase 600 , quando o Governo iniciou o pagamento das devidas indenizações às pessoas contaminadas pela cápsula de Césio 137 e o seu fascinante e maravilhoso "pó azul".

A partir daí a incerteza quanto ao efetivo nexo de causalidade entre o acidente radiológico e estas "novas" vítimas torna-se bastante evidente, necessitando-se de conhecimentos específicos para esta constatação, que muitas vezes mostra-se impossível.

Assim, além daqueles que foram efetivamente contaminados, alguns desenvolvendo depressão da medula óssea, também devem ser considerados os que necessitaram de acompanhamento psicológico para superarem a crise que se abateu sobre a cidade, ou seja, dano imediato para os primeiros e dano mediato neste último caso.

Quanto aos proprietários da clínica onde foi encontrado o material radioativo, estes foram condenados na esfera criminal a três anos de detenção, devendo ainda responder civilmente pelos mencionados danos, computando-se aí danos patrimoniais e danos morais. Digno de menção a impossibilidade de aplicação dos dispositivos elencados na Lei $n^{\circ} 6.453 / 77$ que dispõe sobre a responsabilidade civil e criminal sobre atividades nucleares, exatamente porque em seu artigo 16 ficou explicitado que referida lei não é aplicável nos casos de danos causados por emissão de radiações ionizantes que não em acidente nuclear.

E como a definição de acidente nuclear possui parâmetros específicos, o acidente de Goiânia não pôde ser abarcado pelos dispositivos daquela legislação.

Outra questão que também assola a opinião pública diz respeito ainda aos rejeitos radioativos provenientes desta contaminação. E mais uma vez a desinformação e o medo injustificado da população, fez com que medidas extremas fossem tomadas a esse respeito, como 0 armazenamento de um volume de $3.500 \mathrm{~m} 3$, contendo aproximadamente 1.250 Ci de Césio 137. Os containers encontra-se provisoriamente estocados em Abadia de Goiás, localizada há 30 quilômetros de Goiânia. E esta provisoriedade, que demorou cerca de sete anos para ser decidida pelo Governo, causou e vem causando aquilo que os profissionais da área nuclear tanto lutam para desmistificar - a repúdia da população pelo medo do desconhecido"86. 
nuclear de Angra dos Reis e de mineradoras que trabalham com material radioativo na extração mineral, não dispondo de soluções definitivas para disposição dos rejeitos produzidos, contudo, deixa a critério dos municípios a faculdade de aceitar ou não tratar destes rejeitos mediante remuneração.

\subsection{Interpretação constitucional e sua flexibilidade: na busca de celeridade e da regulamentação do Direito nuclear}

Inicialmente é importante se observar que o direito nuclear só ganha legitimidade a partir da sua realização na prática, pois é a partir da interpretação constitucional é que se melhor ampara a divisão de poderes e prerrogativas dos entes federados, na busca de um resultado que aperfeiçoe as diretrizes constitucionais apresentadas.

Daí a razão de Martin Kriele ${ }^{59}$ afirmar que não se pode interpretar nenhum texto jurídico a não ser se colocando em relação com problemas jurídicos concretos com as soluções aos casos ocorrentes, porque é somente na sua aplicação aos fatos da vida e na concretização, que necessariamente se processa, que se revela completamente o conteúdo significativo da norma. A esse fenômeno se utiliza a chamada neo-hermenêutica constitucional.

A neo-hermenêutica constitucional é a reaproximação axiológica aos valores, e, sobretudo, o reconhecimento da normatividade dos princípios. Esses passaram a ser a síntese dos valores abrigados no ordenamento jurídico e na sociedade, cujo papel principal é condensar valores, dar unidade ao sistema e condicionar a atividade do intérprete ${ }^{60}$.

A neo-hermenêutica constitucional não abandona a teoria geral da subsunção convencional, contudo agrega as seguintes características: normatividade dos princípios, efetividade das normas constitucionais, até mesmo quanto as normas axiológicas, em razão da força normativa da CF/88, a filtragem constitucional - fenômeno que acarreta repercussão aos outros ramos do direito dos princípios constitucionais de forma a apreciar seus institutos da Carta Magna e o uso da interpretação aos casos específicos com a utilização do raciocínio indutivo.

Dessa forma, as consequências da neo-hermenêutica constitucional são: 
1) Queda da crença de que as normas jurídicas em geral e as normas constitucionais em particular trazem sempre em si um sentido único, objetivo, válido para todas as situações sobre as quais incidem um sentido unívoco. À vista dos elementos do caso concreto, dos princípios a serem realizados é que será determinado o sentido da norma, com vistas à produção da solução constitucionalmente adequada para o problema a ser resolvido. Tanto porque 0 Direito Constitucional trabalha conceitos abertos, cláusulas dilatórias e principiológicas que dependem da realidade subjacente, de sorte que não apresentam sentido unívoco e inexorável para todas as situações da vasta realidade fática e valorativa.

Surge no Direito Constitucional uma interpretação evolutiva, de forma que a sistematização, a hierarquia de fins não é historicamente fixa, mas depende da assunção de meta valores por parte da interpretação adequada aos fatos emergentes. Supera-se, portanto, a visão hermética do originalismo no âmbito do Direito Constitucional, pois o direito evolui com a sociedade.

Enfim, as normas constitucionais firmam uma moldura dentro da qual se encontram distintas aplicações, e todas são interpretações jurídicas conforme o direito se inserta nesse quadro. E somente à luz das circunstâncias do caso concreto e da interação dos valores, ter-se-á que determinar o sentido da norma que atende os valores constitucionais preponderantes para o problema a ser solucionado.

2) A relevância da ponderação da análise de casos em conflitos. Para força da efetiva normatividade dos princípios no sistema jurídico releva a distinção entre regras e princípios, ou seja, a resposta da norma da decisão advém não só das regras, mas também dos princípios que arejam a sistemática jurídica e modulam maior sensatez aos valores que fundamentam o ordenamento jurídico.

Vivencia-se, pois, o reconhecimento da efetividade dos princípios ${ }^{\mathrm{XVVIII}}$ como fundamentos constitutivos e normativos do direito, o que conduz à possibilidade de uma interpretação conforme os princípios. Recorrer a um princípio significa formular uma regra com base na qual se resolve o caso em tela, modificando-se a ingênua convicção de que as regras já se encontram formuladas antes da sua aplicação e que, portanto, a tarefa do Poder Judiciário limita-se a

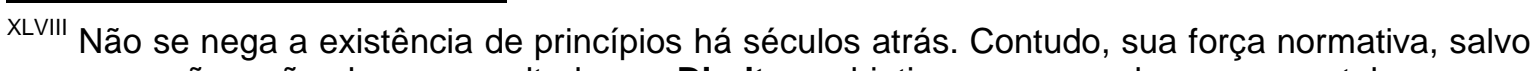
raras exceções, não alcança resultados ou Direitos subjetivos para aqueles que a postula. 
aplicar a regra apropriada ao caso. Enfim, cuida-se da passagem metodológica da ratio legis à ratio iuris, isto é, do sentido da norma legal ao sentido dos fundamentos do próprio sistema.

3) Regra que ordinariamente seja interpretada como constitucional, por força de elemento do próprio contexto e originalidade dos fatos concretos quando vulnerado o núcleo essencial do princípio, isto é, quando constatada a perda total do valor constitucional protegido pelo princípio sem se acautelar o mínimo vital desse interesse juridicamente protegido - ter-se-á conflito entre o valor constitucional positivado no princípio, o que enseja um efeito de inconstitucionalidade a ser conferido pelo intérprete. Constatada essa hipótese, deve-se paralisar a eficácia da regra, em nome do valor ou princípio constitucional vulnerado - até porque é imperativa a consideração no processo interpretativo do seu impacto na realidade, para se saber se o produto da incidência na norma se realiza finalisticamente o mandamento constitucional e não a razoabilidade dos atos normativos.

\subsubsection{Multiplicidade de centros normativos}

Inicialmente é importante observar que a neo interpretação constitucional é um processo que agrega novos elementos e confere eficácia aos preceitos diretivos da Carta Republicana, pondera novas formas de elucidar problemas sob um viés metodológico que confere maior ênfase ao resultado e ao prisma macro do sistema.

Sublinhou-se, ainda, que apesar da utilização do método dedutivo normativo clássico, o sistema piramidal de normas ainda é preservado, contudo sua interação é de maior dinâmica e complexidade, frente aos princípios e cláusulas dilatórias que encerram posicionamento fluido à luz da sensibilidade do caso concreto e das circunstâncias que sopesam sua aplicação. Enfim, as regras permanecem, embora não impedem de modo onipotente e exclusivo ainda permanece ativo o positivismo.

E, para alcançar legitimidade nessa tarefa, nada mais sensato do que se basear em uma interpretação sistemática. Nesse sentido, faz-se assim suspeita ou falha toda análise interpretativa de normas constitucionais tomadas à margem do amplo contexto que deriva o sistema constitucional. De modo que 
nenhuma liberdade ou direito, nenhuma organização ou construção do estado será idônea fora dos contornos da interpretação sistemática, única apta a iluminar a regra constitucional em todas as suas possíveis dimensões de sentido para exprimir-Ihe corretamente $o$ alcance e grau de eficácia ${ }^{61}$.

\subsubsection{Antinomias e a taxonomia na análise dos conflitos}

Primeiramente é importante definir a antinomias, ou seja, a situação de incompatibilidade de regramento entre normas. Sua constatação é tão antiga quanto a do ordenamento jurídico, eis que remota a Justiniano, contudo, requer uma análise lógica para se deparar de fato com regramentos contraditórios. Tradicionalmente, voltados para a análise infraconstitucional, os juristas apontam três critérios para superá-las, quais sejam: o critério cronológico; o critério hierárquico e o critério da especialidade.

Entretanto, no âmbito do Direito Constitucional são insuficientes para a análise de antinomias da legislação dos entes federados. A primeira questão que emerge é justamente a preponderância dos preceitos e diretrizes constitucionais, pois a análise da legislação infraconstitucional deve ser aferida sob o foco constitucional; a leitura da legislação deve ser realizada primariamente sob as lentes dos preceitos constitucionais. Logo, frente a construção constitucional do regime de competências dos entes federados, não há que se falar em critério cronológico para aferir eventual antinomia, nem tampouco o critério hierárquico. Válido, porém, o critério da especialidade para aferir a base constitucional de competência que abriga a lei em foco ou as leis em foco que se entrelaçam.

Enfim, deve-se analisar primeiramente a taxionomia da legislação, isto é, a sua respectiva fundamentação constitucional na partilha da competência entre os entes federados. Assim, o crivo inicial é justamente conferir resposta à indagação: Em qual preceito constitucional de competências tem arrimo o texto legislativo sob análise?

Para conferir a referida resposta sobre competências, dois fatores são de essencial análise: o objeto jurídico que se está a tutelar pela legislação, que no caso da presente pesquisa é o Direito nuclear e a finalidade da legislação frente à especificidade de seus regramentos no âmbito federal, estadual e municipal. 
Pelo primeiro critério, deve-se perquirir os considerando da lei, a necessidade constatada para a legislação e, sobretudo, o grau de interesse em foco para se constatar qual objeto jurídico preponderante ao tema objeto da legislação; enfim, qual o interesse preponderante em foco, ou seja, a proteção radiológica.

Já os segundo critério busca elucidar a finalidade da lei, qual o seu intento e sua especialização no universo das normas apto a diferenciá-la de uma ou outra categoria jurídica para a correspondente qualificação constitucional de competência. Esse critério foi sintetizado como a especificidade da lei, o objeto específico da lei, cuja resposta deverá nortear a sua classificação/antinomia. Daí é preciso apartar assuntos díspares que são concomitantes e interrelacionados a partir da finalidade da lei.

Um exemplo desses critérios são as peculiaridades interpretativas das normas municipais frente ao federalismo, pois conforme já elucidado anteriormente, a tônica lançada pelo constituinte para legitimar a competência municipal é justamente a referência ao interesse municipal a regrar sobre Proteção ambiental na esfera nuclear. A notoriedade do interesse municipal alicerça, pois, a legitimidade da legislação municipal e sua interação com as demais normas, e, consequentemente, com a interpretação e solução de eventuais conflitos.

A interação de normas é consequência inerente ao federalismo, pois apresenta diversas fontes normativas que interagem, de sorte que alguns assuntos tem ingerências de legislações federais, estaduais e municipais como é o caso dos aspectos da proteção radiológica e do direito nuclear. Como é sabido, raramente há interesse exclusivo de um ente federado em um determinado assunto, posto que o interesse de um ente político reflete direta ou indiretamente nos outros níveis de Governo. Mas, para se firmar o interesse municipal, nos termos do art. 30, I da CF/88, é preciso que o interesse do município se sobreponha aos interesses dos demais entes políticos, por razões fáticas e jurídicas legitimas.

Em outros termos, exige-se a preponderância da envergadura do interesse municipal sobre os demais ente federados, para se ter como legítima a legislação municipal sobre o Direito nuclear. 
Já no que se refere às antinomias no âmbito da competência concorrente, é importante analisar, primeiramente, que os comandos constitucionais federais (art. $24, \S 1^{\circ}$ e $\S 4^{\circ}$ da CF/88 ${ }^{\text {XVIII }}$ ), são: a competência da União limitar-se-á a estabelecer normas gerais e a sobreposição das normas federais frente à legislação estadual no que lhe for contrário.

Diante de tais preceitos, entende-se que em sede de legislação geral, as normas federais são superiores, pois suspenderão a eficácia da legislação estadual que disponha em contrário. Contudo, resta analisar sobre o que se entende por normas gerais.

Primeiramente, nota-se que esse limite não foi fixado satisfatoriamente pela jurisprudência, justamente por de tratar de conceito amplo que gera insegurança no âmbito da competência concorrente. Sobre o assunto, Diogo de Figueiredo Neto $^{62}$ ressalta que há três graus de generalização normativa: um generalismo, onde se situam as normas-princípio; um geral, onde se situam as normas gerais e, por fim, um sub geral, que é das normas particularizantes. Já em relação as normas gerais, aponta os seus genéricos,

\begin{abstract}
a) Estabeleçam princípios, diretrizes e regras jurídicas gerais; b) não entram em pormenores e detalhes, não esgotando o assunto legislado; c) devem possuir abrangência nacional, aplicando-se igualmente a todas as entidades federadas; d) devem ser regras uniformes para situações homogêneas; e) cabem em áreas de conflito (entre entidades federadas); f) referem-se a questões fundamentais.
\end{abstract}

Vislumbra-se, daí, a conotação da uniformidade nacional, como típica característica para as normas gerais da união, também chamadas por alguns doutrinadores de normas nacionais, pois aplicáveis a toda Federação. Esse o intento do constituinte, cuja diretriz fora justamente impedir conflitos de conceitos fundantes e de políticas nacionais. Neste raciocínio pondera Marcelo Araújo ${ }^{63}$ :

$\mathrm{Na}$ verdade, a possibilidade dos Estados-membros legislarem atendendo as suas peculiaridades deve respeitar um mínimo de uniformização legislativa que terá sua fronteira traçada por normas da União. Ou seja, se o constituinte relacionou determinadas matérias como integrantes de uma competência legislativa concorrente não cumulativa, é porque viu nelas essa necessidade e um mínimo de uniformização, sem que isso signifique centralização de acordo com a realidade concreta dos casos por eles vividos.

A dificuldade reside em encontrar o equilíbrio entre a uniformidade e a diversidade legislativa. Equilíbrio este que deverá ser buscado através do princípio de subsidiariedade. Na verdade, ao prever a Constituição Federal de 1988, em seu art. 24, matérias que recebiam a atenção de variados entes federados, teve o constituinte em conta exatamente a 
percepção da necessidade de proporcionar a diversidade dos Estadosmembros, equilibrando a diversidade com a unidade do Estado Federal (...).

Vê-se, assim, que no condomínio legislativo a União possui uma função de estabelecer, por meio de normas gerais, um núcleo mínimo que merece respeito quando do desenvolvimento das competências legislativas pelos Estados-membros, a fim de organizar as legislações que, emanadas das fontes diversas, tenham por objeto um mesmo assunto.

Integram as regras constitucionais de convivência suplementar que é exercida pelos Estados-membros. Na verdade, trata-se de encontrar um meio de fazer que as atividades legislativas compartilhadas não entrem em choque. Foi com essa intenção que o Constituinte elaborou os parágrafos do art. 24 supra mencionados.

Enfim, diante destas características denotam-se os caracteres genéricos de integração das normas gerais para as instituições bases de uma política legislativa sobre determinado assunto, de forma a franquear margem de regramento próprio aos Estados-membros por meio de normas particularizantes, baseado em uma correlação de integração e autonomia.

Justamente para a preservação da autonomia dos entes federados, consistente na possibilidade de se firmar diferenças para atender peculiaridades próprias, ter-se-á o equilíbrio perquirido pelo constituinte ao insistir as competências concorrentes. Observa-se, portanto, que o foco é justamente o respeito à margem de espaço próprio dos estados-membros para que possam regulamentar interesses que Ihe são peculiares, sob a análise do próprio federalismo, a preservação da diversidade na unidade.

\subsubsection{Tratados internacionais: celeridade na solução de conflitos e maior regulamentação na Segurança e Proteção radiológica}

Inicialmente é importante se observar que no que se refere a proteção e segurança radiológica há muitas normas internacionais que são utilizadas no direito nuclear para regulamentar estas atividades. Com efeito, os desdobramentos destas normas repercutem no encaixe das normas positivadas pelos demais entes federados.

Assim, salvo a exceção contida na Emenda Constitucional №. 45, os tratados e normas internacionais, em regra, submetem-se ao sistema jurídico pátrio no âmbito infraconstitucional, pois são fonte imediata do Direito Internacional, seara extraordinária do direito que tem características próprias 
condizentes à sua natureza jurídica tão peculiar. Entre essa constatação de a sociedade internacional é descentralizada, ao contrário do âmbito interno próprio dos demais ramos do direito, não há autoridade superior que efetive ou garanta a aplicação de suas normas. Ensina Resek ${ }^{64}$ que por isso os estados se organizam horizontalmente, e prontificam-se a proceder de acordo com normas jurídicas na exata medida em que estas tenham constituído objeto de seu consentimento. A criação das normas é, assim, obra direta de seus destinatários.

Decorre daí relações de coordenação entre os aplicadores e destinatários das normas de Direito internacional Público, ao passo que na relação jurídica interna firma-se a ideia de subordinação.

Releva-se dessas observações o compromisso efetivo pelo consentimento dos estados, do pacta sunt servanda, ou seja, da força do próprio pacto celebrado segundo a palavra e o compromisso moral de seu cumprimento. Daí a notável importância da boa-fé objetiva ao cumprimento dos acordos e do próprio princípio da reciprocidade que condiciona e equilibram as relações jurídicas dos estados aos seus respectivos direitos e obrigações, premissas que devem nortear o jurista na interpretação dessa especial seara do direito. Essa observação é expressamente apontada nos considerandos da convenção de Viena como universalmente reconhecidos, condições necessárias à manutenção da justiça e do respeito das obrigações resultantes dos Tratados e normas internacionais, diante dos princípios de igualdade dos direitos e autodeterminação dos povos, da igualdade soberana e independência de todos os estados.

Portanto, a interpretação dos Tratados e das normas internacionais deverão ser firmadas segundo as normas de Direito internacional, conforme aponta a teoria da adoção, segundo a qual o fato de uma recomendação ser aplicável no direito interno de um estado contratante não lhe faz perder sua natureza internacional. Ora somente assim, ter-se-á preservado o princípio do consensualismo contratual entabulado entre as partes na elaboração do tratado ou acordo internacional. 


\section{RESULTADOS E DISCUSSÃO}

\subsection{No âmbito federal}

Em que pesem as especificidades políticas e jurídicas do contexto histórico brasileiro, desde a implementação das primeiras leis, passando por período de ditadura militar ou de governo de transição para a democracia, é possível verificar que o domínio do conhecimento científico e tecnológico foi fundamental para o desenvolvimento sustentável do país, entendido como fonte estrutural para a inserção internacional brasileira no setor de energia nuclear.

Contudo, a atuação do estado, no desenvolvimento das atividades nucleares, esta sujeita a regimes jurídicos distintos, sendo necessário um estudo adequado da natureza das atividades desenvolvidas para a devida compreensão da legislação e instrumentos regulatórios aplicáveis a cada caso ou situação.

$\mathrm{Na}$ esfera econômica, a atuação estatal dar-se-á de forma indireta, atuando a União como agente normativo, fiscalizador, incentivador e planejador das atividades, sendo permitida a intervenção direta, "quando necessária aos imperativos de segurança nacional ou relevante interesse coletivo, conforme definidos em lei" ${ }^{65}$.

A intervenção excepcional do Estado na ordem econômica poderá se concretizar sob a forma de monopólio, quando a União atua de forma exclusiva em determinada área ou por meio de empresas públicas, sociedades de economia mista e subsidiárias, quando o Estado atua em concorrência com a iniciativa privada. 
Trata-se da consagração do princípio da subsidiariedade ${ }^{X L I X}$ na ordem e econômica constitucional, legitimando-se a intervenção estatal na Economia apenas quando o interesse público exigir a correção de disfunções sistêmicas.

Além do princípio da subsidiariedade ${ }^{66}$, a Constituição da República Federativa do Brasil de 1988 estabeleceu outros princípios que norteiam o desenvolvimento de atividades econômicas ligadas à energia nuclear, dentre eles estão o princípio da soberania nacional; o princípio função social da propriedade e o princípio defesa do meio ambiente, que possui tratamento diferenciado conforme o impacto ambiental dos produtos e dos serviços e do desenvolvimento das atividades nucleares (art. 170 do referido diploma legal). Este aspecto ambiental será analisado mais adiante.

Dessa forma, como regulador da atividade econômica, o Estado exercerá as funções de fiscalização, incentivo e planejamento, atuando na fiscalização dos agentes, visando coibir o abuso do poder econômico, tendente à dominação dos mercados, como fomentador da atividade econômica e no planejamento econômico, que será "determinante para o setor público e indicativo para o setor privado", nos termos do art. 174 da Carta Magna de 1988.

Essas hipóteses de intervenção estatal indireta, segundo Eros Roberto $\mathrm{Grau}^{67}$, são classificadas como intervenção por direção, quando "o estado exerce pressão sobre a economia, estabelecendo mecanismos e normas de comportamento compulsório para os sujeitos da atividade econômica em sentido estrito" e intervenção por indução, quando "o estado manipula os instrumentos de

XLIX O princípio da subsidiariedade está indubitavelmente presente na Ordem Econômica Brasileira, o que se faz mais cristalino com as recentes mutações constitucionais verificadas nesse âmbito, que vieram sob o manto do consenso na necessidade de adequação à nova realidade mundial.

Sabe-se que em um Estado de Direito a reestruturação do papel do poder público não se pode efetivar, em especial nos países regidos por Cartas analíticas como a brasileira, senão por via constitucional, cabendo ao poder constituinte originário ou derivado adotar as opções políticas básicas por que se deve se orientar o Estado. E no Brasil, como não poderia deixar de ser, as profundas transformações econômicas que se vêm verificando em escala mundial sensibilizaram, ainda que modestamente, os elaboradores da Constituição de 1988 e mobilizam, com mais ardor, o constituinte derivado. A despeito das severas críticas que recebeu e ainda recebe a nossa carta constitucional, soube ser compromissória e casuística, o certo é que o constituinte de 1988 houve por bem dar uma abertura, ainda que acanhada, a uma nova estruturação do Estado brasileiro, impedindo, na ordem econômica, a proliferação do intervencionismo estatal e erigindo a iniciativa e a propriedade privadas em valor social, a teor do art. $1^{\circ}$, IV. Consagrou a nossa Lei Fundamental, já em seu texto originário, a livre iniciativa e a economia descentralizada, restringindo a atuação estatal direta a motivos previamente nela própria tipificados, a saber, quando necessária aos imperativos de segurança nacional ou a relevante interesse coletivo (art. 173). Revelou, ademais, o Estado como supervisor da ordem econômica, apto a impedir abusos e desvios do poder econômico (art. 173, $\left.\S 4^{\circ}\right)^{87}$. 
intervenção em consonância e na conformidade das leis que regem o funcionamento dos mercados".

Quanto à atuação direta, o Estado brasileiro intervirá diretamente e exclusivamente no domínio econômico sob o regime monopolista nas atividades elencadas nos art. 177 da Carta Constitucional de 1988, que são: a pesquisa e a lavra das jazidas de petróleo e gás natural e outros hidrocarbonetos fluidos; a refinação do petróleo nacional ou estrangeiro; a importação e exportação dos produtos e derivados básicos resultantes das atividades previstas nos incisos anteriores; o transporte marítimo do petróleo bruto de origem nacional ou de derivados básicos de petróleo produzidos no País, bem assim o transporte, por meio de conduto, de petróleo bruto, seus derivados e gás natural de qualquer origem e na pesquisa, a lavra, o enriquecimento, o reprocessamento, a industrialização e o comércio de minérios e minerais nucleares e seus derivados, com exceção dos radioisótopos cuja produção, comercialização e utilização poderão ser autorizadas sob regime de permissão.

Ademais, a intervenção direta do Estado na ordem econômica também poderá se configurar em regime concorrencial, quando necessário "aos imperativos da segurança nacional ou a relevante interesse coletivo, conforme definidos em lei" ${ }^{7}$, como previsto no art. 173 da Carta Magna de 1988. Nessas hipóteses, a atuação do Estado, em concorrência com a iniciativa privada, manifestar-se-á por meio da criação de empresas públicas, sociedades de economia mista e subsidiárias, que atuarão especificamente no desenvolvimento dessas atividades.

Contudo, ao se analisar o art. 177, inciso $V$ da Constituição da República Federativa do Brasil de 1988, verifica-se que o monopólio das atividades nucleares restringe-se à "pesquisa, a lavra, o enriquecimento, o reprocessamento, a industrialização e o comércio de minérios e minerais nucleares e seus derivados, com exceção dos radioisótopos cuja produção, comercialização e utilização poderão ser autorizadas sob regime de permissão"7 estaria excluída do monopólio, já que o texto constitucional menciona apenas as atividades de "pesquisa".

Entretanto, fugindo-se de uma hermenêutica literalista, percebe-se que a intenção do legislador constituinte não foi proceder à exclusão de atividades do âmbito do monopólio, mas sim efetuar um detalhamento das atividades entregues 
a este regime econômico. Registre-se que esta técnica legislativa não foi utilizada na redação do art. 177, V da Carta Magna de 1988.

Embora o texto constitucional não apresente o conceito de instalação nuclear, é importante analisar-se a definição trazida na Lei no. 6.453/7768, que dispõe sobre a responsabilidade civil por danos nucleares ${ }^{\mathrm{L}}$ e não a excluí do monopólio estatal, pois as atividades monopolizadas são desenvolvidas em instalações nucleares. O que não significa que todas as atividades desenvolvidas em instalações nucleares estejam incluídas no regime monopolístico.

Importante destacar, ainda, que as atividades nucleares monopolizadas não são apenas desenvolvidas em instalações nucleares, sendo a atividade de industrialização de minérios nucleares e derivados também executada em instalações radiativas, nas quais são produzidos os radioisótopos que são utilizados nas áreas médica, agrícola, industrial e em pesquisas.

Em relação às instalações nucleares, nem todas as atividades nelas desenvolvidas estão incluídas no regime monopolístico estatal, como por exemplo, a operação de usinas nucleoelétricas. É que a atividade desenvolvida nestas usinas, geração de energia elétrica, não se enquadra no rol de atividades monopolizadas pelo Estado, no setor nuclear, isto é, "a pesquisa, a lavra, o enriquecimento e reprocessamento, a industrialização e o comércio de minérios nucleares e seus derivados"7.

Embora a usina nuclear seja uma instalação na qual há a utilização de material nuclear, trata-se de uma usina termelétrica, assim como a usina a carvão, que se distingue das demais pela utilização de combustível nuclear.

Dessa forma, trata-se de uma hipótese de atuação direta do Estado, no desenvolvimento de atividade econômica em sentido estrito, em concorrência com a iniciativa privada, atividade esta, atualmente desenvolvida pela Eletrobrás Termonuclear S/A, sociedade de economia mista especialmente constituída para

\footnotetext{
L "Art. $1^{\circ}$ - Para os efeitos desta Lei considera-se: (...) VI - instalação nuclear: a) o reator nuclear, salvo o utilizado como fonte de energia em meio de transporte, tanto para sua propulsão como para outros fins; b) a fábrica que utilize combustível nuclear para a produção de materiais nucleares ou na qual se proceda a tratamento de materiais nucleares, incluídas as instalações de reprocessamento de combustível nuclear irradiado; c) o local de armazenamento de materiais nucleares, exceto aquele ocasionalmente usado durante seu transporte" ${ }^{\prime 8}$.
} 
essa finalidade, mas que também poderá ser executada por empresas concessionárias de energia elétrica, como previsto no art. 10 da Lei $n^{\circ} 6.189 / 74^{\mathrm{LI}}$. Assim, tem-se que a natureza jurídica das atividades econômicas desenvolvidas no setor nuclear e os regimes jurídicos aplicáveis, partindo-se da aplicação do princípio da subsidiariedade, dar-se-á principalmente no campo da regulação federal. No exercício da função regulatória estatal, no campo das atividades nucleares, a legislação atribuiu esse mister à Comissão Nacional de Energia nuclear - CNEN que, embora não seja dotada da estrutura de uma agência reguladora ${ }^{\text {LII }}$, vem desempenhando há muitos e muitos anos essa função.

Com relação à seção 6.3.3 que trata das relações internacionais tornase de bom alvitre a legislação e normatização nuclear acatar a internacional estabelecida pelo Organismo Internacional de Energia Atômica, órgão oficial da Organização das Nações Unidas do qual o nosso país é membro, para não ser prejudicado dentro da comunicação e intercâmbio internacionais. O que se pode

LI "Art. 10. A autorização para a construção e operação de usinas nucleoelétricas será dada, exclusivamente, à Centrais Elétricas Brasileiras S.A. - ELETROBRÁS e a concessionárias de serviços de energia elétrica, mediante ato do Poder Executivo, previamente ouvidos os órgãos competentes.

Parágrafo único. Para os efeitos do disposto neste artigo compete:

a) à CNEN, a verificação do atendimento aos requisitos legais e regulamentares relativos à energia nuclear, às normas por ela expedidas e à satisfação das exigências formuladas pela Política Nacional de Energia Nuclear e diretrizes governamentais para a energia nuclear;

b) ao Departamento Nacional de Águas e Energia Elétrica - DNAEE, a verificação do preenchimento dos requisitos legais e regulamentares relativos à concessão de serviços de energia elétrica, ouvida a ELETROBRÁS quanto à verificação da adequação técnica, econômica e financeira do projeto ao sistema da concessionária, bem assim, sua compatibilidade com o plano das instalações necessárias ao atendimento do mercado de energia elétrica;

c) à CNEN e ao DNAEE, nas respectivas áreas de atuação, a fiscalização da operação das usinas nucleoelétricas" ${ }^{\circ 9}$.

LII É importante observar que há duas definições de agência. Segundo Dicionário da Língua Portuguesa, agência é, entre outras definições, "empresa que presta serviços remunerados, geralmente servindo de intermediário, na gestão de negócios ou assuntos alheios (ex.: agência de investimentos, agência de viagens, agência funerária)"90.

Contudo, em relação ao significado jurídico, agência é "pessoa jurídica de Direito público interno, geralmente constituída sob a forma de autarquia especial ou outro ente da administração indireta, cuja finalidade é regular e/ou fiscalizar a atividade de determinado setor da economia de um país, a exemplo dos setores de energia elétrica, produção e comercialização de petróleo. As agências reguladoras são criadas através de leis e tem natureza de Autarquia com regime jurídico especial. Consistem em autarquias com poderes especiais, integrantes da administração pública indireta, que se dispõe a fiscalizar e regular as atividades de serviços públicos executados por empresas privadas, mediante prévia concessão, permissão ou autorização. Estas devem exercer a fiscalização, controle e, sobretudo, poder regulador incidente sobre serviços delegado a terceiros. Correspondem, assim, a autarquias sujeitas a regime especial, criadas por lei para aquela finalidade especifica. Diz-se que seu regime é especial, ante a maior ou menor autonomia que detém e a forma de provimento de seus cargos diretivos (por mandato certo e afastada a possibilidade de exoneração ad nutum, ou seja, a qualquer momento). Não são, porém, independentes. Estão sujeitas ao mesmo tratamento das autarquias, e passiveis de idênticos mecanismos de controle" ${ }^{\prime 6}$. 
fazer é adaptar o sistema internacional aos moldes nacionais. Dá-se um exemplo concreto a respeito da normatização na radioproteção.

Atualmente existem limites anuais de doses para os trabalhadores e para o público. Suponha-se que no Brasil estabeleça limites para os trabalhadores mais restritivos do que aqueles que seguiram os internacionais como os Estados Unidos devido ao parco desenvolvimento no setor nuclear.

Se em um intercâmbio científico, um brasileiro for para os Estados Unidos e por infelicidade contrair um câncer, a empresa responsável pelo trabalhador sofrerá as consequências e as penalizações. A primeira pergunta que o advogado de defesa do trabalhador fará a empresa será: por que mandou o funcionário para um país que não fornecem as mesmas condições de proteção e segurança do Brasil? Provavelmente a empresa pagará indenizações e multas por isso.

Diante de todo o exposto, contudo, resta uma dúvida abordada anteriormente: como coadunar, então, estas regras monopolizadas com as regras de competência estabelecidas quanto ao princípio da defesa do meio ambiente, uma vez que este possui uma expressividade em seu caráter humanístico? A questão não é simples de ser respondida, tampouco pacífico é o seu entendimento.

Para os aspectos relativos ao meio ambiente, as regras permitem a delegação de competência, inclusive com casos de competência concorrente entre união, estados e municípios, principalmente quando o assunto se refere a rejeitos radioativos, sendo possível a intervenção das três esferas para que se impeça a proliferação de um possível mal a sociedade.

No entanto, a crítica que se tece é a excessiva pormenorização das atribuições de competências da União em matérias que poderiam ser conferidas aos estados, quer no texto constitucional, quer na legislação ordinária, que ainda na interpretação das competências e do federalismo pelos Tribunais e órgãos do setor público.

Esta crítica é condizente por Ives Gandra Martins ${ }^{69}$ que endossa esse posicionamento nos seguintes tem-se: 
são matérias de relevância menor nas atribuições dos entes federativos, motivo pelo qual se poderia, perfeitamente, permitir que os Estados e municípios cuidassem, em suas esferas de atuação, de regular matéria. $\mathrm{E}$ nem por isso creio que haveria discrepância de monta entre as legislações de cada ente federativo. A não privatização da competência, hoje, em mãos da União representaria, por um lado, um respeito necessário à autonomia federativa. $\mathrm{O}$ argumento de que os sorteios $\mathrm{e}$ consórcios poderiam gerar conflitos nas áreas de atuação de cada ente federativo em relação aos cidadãos, que teriam que conviver com legislação díspar de cada um deles, não resiste à observação de que o consorciado se obriga a regra do plano a que adere, conhecendo inteiramente seus Direitos e deveres.

È importante ressaltar que a doutrina é dividida quanto á necessidade de delegação uniforme para todos os estados ou delegação diferenciada entre estados quando presentes razões fáticas para tanto. De um lado, alguns pregam a busca de correções das assimetrias de fato, o que autoriza a delegação a somente um ou alguns dos entes federativos, pois a delegação é baseada, por natureza, em critérios políticos discricionários ao talante do legislador federal frente ás razões fáticas sempre díspares nos entres políticos. Do outro lado, remanesce a necessidade de proteção ao principio constitucional de tratamento igualitário entre os estados, o que obriga a delegação legislativa de modo uniforme.

As críticas ora lançadas no cenário nacional também repercutem internacionalmente quanto ao papel da injusta proeminência da União Federal no jogo das competências legislativas. É justamente nesse sentido o mote da Reforma Constitucional Alemã firmada ao final do ano de $2006^{70}$, que trouxe inéditas regras de compartilhamento de competências entre os entes federados, resultando no expressivo incremento das competências concorrentes, como adiante será pontuado.

Em outros termos, a tendência centrípeta deve-se limitar aos preceitos fundantes do federalismo, justamente para assegurar faixa de autonomia indevassável aos demais entres políticos e, assim, firmar mecanismos que impeçam a exacerbada e desconcertante hegemonia do ente central sobre os demais entres políticos.

Enfim, o que se deve ter como tônica para equacionar os princípios estruturantes, ou as normas de integração nacional entre os entes federados, são os valores estampados na Constituição da República, próprios da República, do regime representativo - os direitos políticos e a responsabilidade politica que 
extravasam o amálgama comum para todos os entes políticos e, como tal, de observância obrigatória - sujeito até mesmo a intervenção sobre o ente federado se desrespeitado tal mandamento (art. 34, VII, a, da Carta Magna de 1988). E nesses estreitos limites, é que se pode falar em regras de simetria constitucional, justamente para preservar o mínimo de coesão á instituições republicanas do Estado Federal e manter a autonomia dos demais entes federados.

Por fim, no âmbito federal, com relação ao aspecto na seção 6.3.2 intitulada "Antinomia e a taxonomia na análise dos conflitos" deve-se informar que isso já existe no Brasil no âmbito normativo nacional.

Diversos ministérios e secretarias federais além de citarem as normas da CNEN produzem suas próprias normas que geralmente diferem chegando a serem contrarias ou contraditórias, provocando conflitos de direito com difícil solução. Este tipo de conflito já ocorreu em vários países com um parque nacional nuclear bem maior que o brasileiro como a França, a Itália, entre outros.

Expor-se-á aqui a título de exemplo e a solução adotada pela Itália sob a égide do "Ente Nazionale Energie Alternative", tradução, "Entidade Nacional de Energias Altervativas" encarregada de estabelecer às normas nacionais, equivalente a CNEN. Convoca-se uma comissão representativa de cada ministério e secretaria interessadas na norma. Esta comisso é formada de dois representantes de cada ministério ou secretaria incluindo dois do "Ente Nacionale" e eles ficarão encarregados de formar uma redação de norma que se torne compatíveis dentro do contexto de cada ministério e secretaria. Esta norma terá caráter nacional e não poderá ser modificada por nenhum ministério ou secretaria.

\subsection{No âmbito estadual}

Inicialmente é necessário frisar que a diretriz histórica do federalismo atual procura conferir maior liberdade aos estados-membros para firmar sua auto legislação ${ }^{71}$ e autodeterminação conforme 0 art. 25 da CF/88, já as vedações e limitações aos estados merecem interpretação restrita, justamente por se tratar de exceção.

Esta constatação advém do mero cortejo de das limitações expressas e principiológicas firmadas na Carta de 1967/69 e da Carta vigente, pois ao compará-las nota-se maior desapego as condicionantes expressas. 
Anna Cândida da Cunha Ferraz ilustra a sistemática condicionante dos princípios estruturantes do federalismo na conjugação da competência legislativa dos estados-membros em cortejo com a coesão exigida pela Federação, nos seguintes termos:

\begin{abstract}
A limitação do Poder Constituinte Decorrente é da essência do próprio federalismo. Impossível conceber um Estado Federal em que as unidades federativas gozem da plenitude do poder; ou detenham soberania. As unidades de uma federação, os Estados-membros, já se disse, tem apenas autonomia constitucional limitada, ou, em outras palavras, dispõem de capacidade de auto-organização e têm competência normativa própria.

Por outro lado, essa limitação do Poder Constituinte Decorrente não pode ser tal, que sufoque os Estados-membros. A virtude fundamental do federalismo - a unidade nacional através da diversidade regional indica que para que o Estado Federal subsista, há um grau mínimo de autonomia constitucional das entidades federativas, o que implica dizer que, na linha desses graus máximo e mínimo, estão os pontos-limites das restrições da amplitude da ação do Poder Constituinte Decorrente ${ }^{72}$.
\end{abstract}

Prossegue a doutrinadora ${ }^{72}$ afirmando que é impossível fixar teoricamente, em termos ideais, os dois pontos-limites (entre o grau mínimo e o máximo de intervenção), de forma que a experiência constitucional recomenda que tais parâmetros sejam retirados do Poder Constituinte Originário, dos subsídios que a doutrina oferece em cortejo com a realidade constitucional, pois a essência do federalismo clama não somente pela técnica de repartição de poderes, como também pelo conjunto de valores essenciais a preservar.

As citadas condicionantes ao Poder Constituinte Decorrente têm implicações de ordem positiva e negativa. Essa última fixa um campo de proibição (de não contrariar seus preceitos), qual seja a necessidade de seguir as disposições da Carta Federal quando explicita comandos diretos, tanto porque fundamento último de validade da ordem jurídica nacional.

Como exemplo das limitações negativas da competência legislativa ${ }^{\text {LIII, }}$ pode-se mencionar entre outros o art. 19 da CF/88 que veda aos estados, Distrito

LIII As implicações positivas repercutem sobre a necessidade dos estados assimilarem modelos
padrões firmados pelo constituinte. Por sua vez, Manoel Gonçalves Ferreira Filho rotula a "pré-
ordenação institucional" os preceitos constitucionais que definem as regras da estrutura dos
órgãos estaduais, ou seja, que versem sobre a auto organização e auto governo dos estados, tal
como as regras de duração do mandato dos eleitos, e imunidades, remuneração, perda de
mandato etc.. Tais regras são firmadas diretamente ou por meio de extensão normativa aos
comandos lançados às instituições federais e suas extensão aos estados (art. 27 , $\S 10^{\circ}$ da CF/88).
Já quanto às determinações constitucionais formatam o instituto regrado, Ferreira Filho qualifica
tais regras como de "subordinação normativa" como nas determinações voltadas aos princípios da
Administração Pública, pois editadas para todos os entes federados. As regras de subordinação
normativa podem ser diretas, quando firmadas na própria CF/88, como imperativos imediatos à 
Federal e Municípios estabelecer qualquer atividade econômica que origina de atividades ou pesquisas nucleares, ressalvada na forma da lei, a colaboração de interesse público, como por exemplo, os aspectos relativos à poluição e aos rejeitos radioativos.

No que se refere aos rejeitos radioativos ${ }^{73}$ é importante se observar que não se utiliza das regras gerais na esfera federal para controlar sua emissão ao meio ambiente descrita na esfera federal, pois, desta forma, estaria se impedindo, por exemplo, a instalação de uma usina nuclear em determinado estado ou município. Assim, o que é feito é a elaboração de normas infraconstitucionais que dispõem sobre os meios de mitigação de eventual poluição, bem como suas restrições, como é o caso, por exemplo, do art. 153 da Constituição Estadual do Rio Grande do Norte ${ }^{\text {LIV }}$. Contudo, é importante destacar que estas normas não são proibições taxativas.

Além disso, há que observar uma regra primordial do princípio da defesa do meio ambiente é que a competência para se tratar de poluição é do foro do local do dano, conforme o art. 24, VIII da Constituição da República Federativa do Brasil de 1988 e art. 31, parágrafo único da Lei ํo. 10.308/01 ${ }^{\mathrm{LV}}$. Em outras palavras, busca-se acima de tudo, regionalizar as soluções, possibilitando que as mesmas sejam apresentadas por aqueles que mais diretamente serão afetados pelo problema.

Dessa forma, é possível verificar que os estados possuem regramentos próprios para alguns aspectos relativos à poluição e aos rejeitos radioativos ${ }^{\mathrm{LV} I}$,

Administração estadual; ou indiretas, quando se faz por meio de legislação nacional obrigatória para todos os estados ${ }^{91}$.

LIV “Art. 153. A lei estadual, observada a limitação imposta por lei federal, disporá sobre o depósito temporário ou permanente de resíduos de material atômico de qualquer origem no território do Estado",

LV “Art. 31. A responsabilidade civil por danos radiológicos pessoais, patrimoniais e ambientais causados por rejeitos nos depósitos provisórios ou durante o transporte do local do acidente para o depósito provisório e deste para o depósito final é da CNEN.

Parágrafo único. A responsabilidade civil pelos danos radiológicos causados por rejeitos armazenados em depósito provisório decorrente de falha na segurança física é do estado" ${ }^{\text {"93 }}$.

LVI No Brasil, a Lei №. 6.189/74 dispõe sobre operações com materiais nucleares, tratamento e eliminação de rejeitos, mas há ausência de disciplina sobre escolha de localização para armazenamento dos resíduos eliminados.

A inexistência de legislação federal acerca da destinação final dos rejeitos nucleares, fica aliada a dificuldades técnicas e principalmente políticas, já que todos têm consciência do problema mas não aceitam a deposição dos rejeitos em seus territórios (fenômeno conhecido como not in my backyard). 
desde que observados integralmente os princípios e as regras norteadoras dispostas no art. 23, VI, VII e parágrafo único da Carta Magna de 1988. Com isso, se torna possível a competência dos estados em estabelecer normas com a finalidade de que seja assegurada uma boa qualidade ambiental, já que os princípios fundamentais da República também devem ser observados ${ }^{\text {LVII}}$.

\subsection{No âmbito municipal}

O município é, portanto, pessoa jurídica de direito público interno, dotado de autonomia politica e administrativa, organizada através da Lei Orgânica do Município, diploma que dita os fundamentos e princípios diretrizes do modelo da organização municipal visada pelo munícipe, elaborada pela própria Câmara Municipal é o que enfatiza a autonomia politica do ente federado, concedida pela Carta de 1891 e em vigor até os dias atuais.

No que se refere a competência, este é privativa ou exclusiva sobre os assuntos de interesse local e implícita também conhecida como indireta quando se tratar de matéria suplementar a legislação federal e a estadual. Dessa forma, vê-se, pois, que o constituinte não limitou rigidamente a área de competência

Isto pode ser bem observado quando da análise de algumas Constituições Estaduais que dispõem sobre a matéria. Assim, como exemplo trar-se-á a Constituição do Piauí que em seu artigo 241 estabelece que "não aceitará depósitos de resíduos nucleares produzidos em outras unidades da federação" "89.

A Constituição de Goiás impõe, pelo artigo 131, parágrafo 2ํㅡㄹ a proibição de "instalação de usinas nucleares, bem como a produção, armazenamento e transporte de armas nucleares de qualquer tipo (...)". E ainda pelo parágrafo $1^{\circ}$ "resíduos radioativos, as embalagens de produtos tóxicos, 0 lixo hospitalar e os demais rejeitos perigosos deverão ter destino definidos em lei, respeitados os critérios científicos,94.

LVII Um grande exemplo que merece ser dado é a observância do princípio da participação federativa, em que a Lei $n^{\circ} .6 .803 / 80$, em seu art. $10, \S 2^{\circ}$ estatui que: "Caberá exclusivamente à União, ouvidos os Governos Estadual e Municipal interessados, aprovar a delimitação e autorizar a implantação de zonas de uso estritamente industrial que se destinem à localização de pólos petroquímicos, cloroquímicos, carboquímicos, bem como a instalações nucleares e outras definidas em lei" "95.

Dessa forma, segundo Paulo de Bessa, "este dispositivo parece introduzir uma consulta ao município, isto é, a tomada de um parecer prévio que não vincula a União. Assim, o município poderá opinar contra e a União decidir a favor. Contudo, da mesma forma, devido a competência concorrente da união, dos estados e dos municípios, a Federação não poderá ser quem na linha decisória profira a decisão. A pessoa de Direito Público interno que há de dizer a última palavra sobre a implantação e delimitações dos locais para a instalações dos pólos petroquímicos e instalações nucleares será o município. E ainda, consequentemente que a união tenha aprovado o projeto, os estados e os municípios conservam o Direito de desaprovar. Fora desse raciocínio jurídico será banir do texto da Carta Magna de 1988 mandamento constitucional com uma tradição de quase quinhentos anos de brasilidade - o municipalismo e sua autonomia", ${ }^{\text {. }}$. 
municipal, ao revés, utilizou-se de expediente elástico para albergar a legislação municipal, critério que se atualiza com os próprios rumos da sociedade.

Arremate-se que no âmbito da competência exclusiva (art. 30, I) o Município detém autonomia constitucional plena, observado os ditames da CF/88, para legislar sobre assuntos de interesse preponderantemente local, de sorte que não se submete aos condicionamentos da legislação federal ou estadual, porquanto essas serão inconstitucionais na medida em que tolherem o legislador municipal de sua autonomia legislativa preconizada constitucionalmente.

Já quanto ao uso de medidas provisórias, observamos que sua utilização é polêmica. Fiel à máxima do federalismo, qual seja, a consecução da unidade nacional através da diversidade regional, sem cercear o acidental, não se vislumbra óbice na sua utilização pelos Municípios, desde que respeitados aos cânones constitucionais então reproduzidos na Lei Orgânica dos Municípios.

Ora, se o ente central optou pelo seu uso, demais entes federados terão autonomia para sua instituição ou não, seja na Constituição Estadual, seja na Lei Orgânica. Interpretação contrária conspurca a autonomia própria do federalismo aspirado pelo constituinte aos entes federados.

Por derradeiro, resta frisar que a criatividade da legislação municipal deve ser melhor explorada na conjuntura nacional - e apoiada pela Jurisprudência constitucional apta a solidificar o federalismo tripartite - de sorte que os municípios possam usufruir com maior ênfase seus interesses e prerrogativas, sobretudo em cidades metropolitanas com desafios de auto organização.

Assim, quer no âmbito do tráfego, do meio ambiente ou do ordenamento territorial da cidade, propugna-se a utilização mais acentuada da auto organização da cidade, através de uma legislação, mais enfática que de fato expresse a prerrogativa municipal para melhor regulamentar o transporte de material radiativo em veículos automotores nas grandes cidades; a implantação de transporte coletivo movido á gás; a limitação de trânsito em áreas centrais da cidade; a recuperação de bairros através de incentivos fiscais e administrativos; a instalação de reatores e usinas nucleares; o descarte e o armazenamento do lixo radiativo e até mesmo o deslocamento de indústrias poluentes para regiões menos populosas em sintonia com a política habitacional. 
Dessa forma, diante do exposto, conclui-se que é preciso, entretanto, definir realmente a competência sobre cada atividade nuclear através da flexibilização e simplificação do processo normativo, principalmente no que se refere ao caráter econômico e ambiental, pois a legislação nuclear nacional encontra-se confusa em matéria de regulação, com a previsão de instrumentos regulatórios inadequados à nova realidade de um setor que tem-se expandido a cada dia, com a utilização de novas técnicas nucleares.

Parece que as autoridades atentaram para essa realidade com a publicação do Decreto $\mathrm{s} / \mathrm{n}$, de 2 de julho de $2008^{74}$, que determinou a constituição do Comitê de Desenvolvimento do Programa Nuclear Brasileiro, em que têm assento os mais diversos Ministérios e competências. Dessa forma, acredita-se que um novo tratamento será dado ao setor nuclear, com o advento de um novo arcabouço normativo, proporcionando uma nova estrutura regulatória unificada, adequada ao desenvolvimento seguro das atividades nucleares ${ }^{75}$. 


\section{CONCLUSÕES}

Ao longo do exame do federalismo no Brasil, consagrado pela Constituição de 1988, é possível extrais algumas conclusões que não esgotam, convém que se registre, toda a problemática examinada na pesquisa.

O federalismo é fenômeno histórico, político e jurídico de divisão de competências legislativas e administrativas entre os entes políticos do Estado. A CF/88 firma a forma de Estado, baseada na descentralização jurídica e política do poder no âmbito territorial desse Estado, ao conferir autonomia aos entes políticos e soberania ao Estado Federal.

O federalismo brasileiro, na Constituição da República Federativa do Brasil de 1988 se apresenta como um federalismo de equilíbrio, no qual as competências dos entes federados (União, estados, municípios e Distrito Federal) estão conjugadas de modo complexo, mediante o critério vertical e horizontal de repartição de competências. Estado federal é a República Federativa do Brasil que representa o todo, dotado de personalidade jurídica de Direito Internacional Público. Já as demais são dotados de autonomia e personalidade jurídica de Direito interno. $O$ federalismo faz da União uma figura de dias faces, que tanto age em nome próprio como em nome da Federação ao expressar sua normativa.

O objetivo do federalismo é a consecução e harmônica manutenção da unidade e diversidade entre as partes federadas, alcançadas pela efetiva distribuição de competências legislativas entre os entes federados na CF/88, o que enseja autonomia aos entes federados, a capacidade de auto organização pela sua própria legislação e administração, sem subordinação imediata aos demais entes federados. 
A CF/88 arrolou expressamente as atribuições materiais da União e suas competências legislativas privativas. Aos estados membros, o constituinte utilizou a técnica da competência remanescente não enumerada. Já os municípios receberam poderes estabelecidos indicativamente, quando presente 0 interesse local, tanto para legislar como administrar, bem como suplementar a legislação federal e estadual no que couber.

O Distrito Federal é também ente federado e congrega as competências próprias dos estados membros e as municipais. Contudo, a União reservou para si a tutela e a legislação sobre organização judiciária do Ministério Público, da Defensoria Pública, da polícia civil e militar, bem como do corpo de bombeiros.

Outra inovação positivada pela CF/88 é a competência concorrente, onde mais de um ente político atua de modo conjunto, tanto na competência administrativa como na seara legislativa. Por meio desta competência, a União estabelece normas gerais sobre o assunto, ao passo que os estados legislam em caráter complementar. Esse fenômeno ocorre, por exemplo, com os aspectos relativos ao meio ambiente, em que as regras permitem a delegação de competência entre União, estados e Municípios, principalmente quando o assunto se refere à poluição, sendo possível a intervenção das três esferas para que se impeça a proliferação de um mal.

A CF/88, por sua vez, estabeleceu de forma expressa que todo o controle acerca do assunto referente a atividades nucleares deve ser exercido pela União, devido à importância existente e à variedade de riscos que devem ser severamente controlados e observados, razão pela qual impede que ocorra qualquer abertura para o setor privado, onde o Estado perderia o controle absoluto, necessário em se tratando de riscos nucleares que, se não monitorados com extremo rigor, podem atingir grande parte da população.

Contudo, estas regras gerais não são utilizadas para determinadas competências materiais, como é o caso, por exemplo, do controle da poluição, pois se assim fosse feito, estaria se impedindo a instalação de uma usina nuclear em determinado estado ou município. E não é isso que se verifica na sociedade.

Assim, neste caso, há como já afirmado anteriormente, a insurgência dos conflitos legislativos, com a elaboração de normas infraconstitucionais 
estaduais e municipais que dispõe sobre os meios de mitigação de eventual poluição, bem como restrições, mas nunca proibições taxativas.

Outro ponto a ser observado no que se refere à competência material no Direito Nuclear, é o foro do local do possível dano ambiental causado, ou seja, visando regionalizar as melhores e imediatas soluções, possibilita a legislação que os danos e as reponsabilidades sejam apresentados por aqueles que mais diretamente serão afetados pelo problema: os municípios. Mas aliado a esta regra, deve estar sedimentado o conceito da hierarquia das normas, permitindo sim que estados e Municípios apresentem regramentos próprios para alguns aspectos relativos à atividade nuclear, como mencionado, desde que observados integralmente os princípios e as regras norteadoras dispostos na Constituição da República Federativa do Brasil de 1988.

Com isso, é possível que estados e municípios estabeleçam normas com a finalidade de que seja assegurada uma boa qualidade ambiental, já que os princípios fundamentais da República também devem ser observados, mas daí a admitir a inviabilização da atividade nuclear em alguns estados-Membros, seria desconsiderar a Política Nuclear hoje vigente no país, e que a duras penas conseguiu a posição atual, mesmo com tantas dificuldades ainda existentes. 


\section{FUTUROS TRABALHOS}

A tecnologia usada na implementação, execução, desenvolvimento e aperfeiçoamento da Energia nuclear é complexa e de vanguarda. Em virtude disto, os países que a detêm completamente são poucos. Com isso, um desenvolvimento amplo de Energia nuclear para a maioria dos países exige parcerias ou importações de diversos elementos.

Tudo isso faz pressupor a existência de uma legislação internacional sobre o assunto, Os países que compõem o órgão das Nações Unidas, ONU, possuem uma entidade conhecida como "Organismo Internacional de Energia Atômica", OIEA, que está encarregada tanto de um sistema legislativo recomendado aos países membros como um sistema de recomendações normativas para as instituições análogas pertencentes aos países membros. A partir desta abertura e relacionado com a presente pesquisa sugere-se os seguintes trabalhos que se consideram pertinentes e todos originais.

1-) Efetuar uma comparação entre a legislação brasileira e aquela recomendada pela OIEA, verificando tanto as partes concordantes como conflitantes e sugerir como redimir estas últimas. Dentro deste contexto, pode-se analisar se a legislação brasileira, em função do parque de aplicações da Energia nuclear presente e em futuro próximo esta condizente ou necessita de melhorias ou atualizações.

2-) Efetuar uma comparação da nossa legislação nuclear com aquela dos países que tem um grau elevado no parque da Energia nuclear como os Estados Unidos, França e outros. Este campo de pesquisa é muito vasto, uma vez que eles podem possuir estruturas governamentais muito diferentes e, portanto, diferirem amplamente com relação as competências de cada órgão. Deve-se lembrar que dentro da estrutura republicana tem-se o Estado de 
federação e confederação e o sistema presidencialista e parlamentarista e provavelmente entrelaçamento dentro da estrutura monárquica, atualmente vigente, os poderes do monarca e dos diferentes órgãos governamentais divergem em muitos aspectos. De todas as estruturas poder-se-á analisar, em princípio, que parte da legislação advém da estrutura governamental e que parte advém da opinião popular de cada país.

3-) Efetuar um trabalho análogo ao citado no item acima (2), mas agora com relação aos países que possuem um Estado de desenvolvimento no campo da Energia nuclear análoga ao Brasil e verificar se é possível usufruir-se de alguns aspectos não contemplados pela legislação brasileira.

Passando, agora do campo internacional para o campo nacional podese, também sugerir os seguintes desenvolvimentos:

a) A Associação Brasileira de Direito Nuclear, em 1980 publicou um compendio, no qual enumerou toda a legislação federal vigente no país até aquela data. Valeria a pena realizar um trabalho de atualização até a presente data mostrando todas as modificações e inovações. Para evitar que se torne uma mera compilação, ainda que a sua publicação seja muito importante, para dar-lhe uma conotação cientifica de pesquisa o realizador, fora da publicação poderia tecer comentários a respeito de se a atual legislação nuclear está pertinente, avançada demais e em que campos ou deixa a desejar e aonde. Neste caso podemos fornecer sugestões e portanto tornar-se uma pesquisa.

b) O tipo de estudo sugerido no item "a" poderia ser realizado a nível estadual para aqueles estados que possuem sua legislação própria incluindo também para eles uma pesquisa de adequacidade.

c) $O$ trabalho de pesquisa mencionado no item "b" poderia também ser realizado a nível municipal.

Os realizadores desses três tipos de pesquisa em seus comentários poderiam via internet, efetuar uma analise de opinião popular por meio de um questionário preparado para este fim. Isso enriqueceria sobremaneira o resultado dos comentários.

Por fim, uma ulterior pesquisa que poderia ser realizada é:

d) Construir um atlas de aplicações utilizando as radiações ionizantes em todos os estados da federação e verificar se mais estados e municípios, além dos atuais, necessitariam de legislação nuclear e em que campo. 


\section{GLOSSÁRIO}

Acidente: é quando a situação potencial que se torna real atinge a população e feri os seus limites de doses anuais primários e secundários, isto é $1 \mathrm{mSv}$ se for irradiação de corpo inteiro.

Competência: (Lat. competentia.) S.f. Poder concedido por lei a um funcionário, juiz ou tribunal para dar parecer e julgar certos litígios ou questões.

Competência horizontal: trata-se de uma rígida determinação do que cada Ente é competente, havendo a enumeração da competência da União e reserva de competência aos Estados e Municípios, havendo um fortalecimento da autonomia dos entes federativos.

Competência vertical: é a relação normativa entre as pessoas estatais, cabendo, à União, estabelecer normas gerais ( $\mathrm{CF} / 88$, art. 24, $\left.\S 1^{\circ}\right)$, e, aos Estadosmembros e ao Distrito Federal, exercer competência suplementar (CF/88, art. 24, $\S 2^{\circ}$ ) deferiu ao Estado-membro e ao Distrito Federal, em inexistindo lei federal sobre normas gerais, a possibilidade de exercer a competência legislativa plena, desde que para atender as suas peculiaridades (CF/88, art. 24 , § 3ํ).

Constituição: (Lat. constitutione.) S.f. Lei fundamental e suprema de um Estado; Carta Constitucional; Carta Magna, que contém normas para a formação dos poderes públicos que formam a própria estrutura do Estado. Comentário: A primeira Constituição do mundo, no sentido moderno e restrito da palavra, foi a magna carta que os barões e bispos ingleses impuseram ao rei João Sem-terra, 19.06.215. A Constituição, segundo J. J. Conotilho ${ }^{97}$, resume uma multiplicidade 
de princípios predominantes, tais como: princípios jurídicos fundamentais, princípios políticos constitucionalmente conformadores, princípios constitucionais positivos, princípio-garantia, "assegurando a cada cidadão e bem assim as limitações que em benefício dele a Constituição impõe aos poderes públicos"; princípios estruturantes e princípios concretos.

Dano: (Lat. damno.) S.m. Mal que se faz a alguém; prejuízo ou ofensa material ou moral, resultante da culpa extracontratual ou aquiliana que importa em responsabilidade civil; prejuízo causado por alguém a outrem, cujo patrimônio seja diminuído, inutilizado ou deteriorado; qualquer ato nocivo, prejudicial, produzido pelo delito.

Dano culposo: Aquele causado pela imperícia, negligência ou imprudência do agente.

Dano doloso: Aquele que é desejado, sendo provocado deliberadamente.

Decisão normativa: Parecer e poder normativo administrativo.

Decreto: (Lat. decretu.) S.m. Determinação de uma autoridade superior, geralmente chefe de Estado (CF/88, art. 84, IV).

Decreto legislativo: Lei aprovada pelo Legislativo, que dispensa aprovação (sanção) do Presidente da República.

Decreto-Lei: Lei oriunda do Executivo; forma totalmente exceptiva, inadmissível durante o funcionamento normal da representação popular no Congresso. No Brasil, admitiu-se em diversos períodos, entre os quais ressalta o de 1937 a 1945, Ditadura de Getúlio Vargas, e de 1964 a 1985, Governo Ditatorial Militar, épocas de governo constitucionalmente irregular, em que o Poder Legislativo foi exercido cumulativamente pelo chefe do Poder Executivo.

Direito: (Lat. directu.) Adj. Correto, não torto. S.m. O Direito, estudo das Leis; nesse sentido, corresponde a jus dos romanos: Jus civile, Jus gentium, Jus 
romanum, Jus publicum etc.; aquilo que está de acordo com o que é reto, evoluindo de acordo com a Lei, conjunto das Leis e a ciência que estuda as Leis; mesmo neste novo sentido, a palavra tem várias acepções, como diziam os romanos: Jus pluribus modis dicitur (a Justiça tem muitos modos de ser dita). $\mathrm{O}$ Direito pode ser objetivo e subjetivo; pode ser considerado como: ciência das normas obrigatórias que regulam a vida do homem em sociedade; Jurisprudência; complexo de normas não escritas, conhecidas como Direito Universal.

Direito Internacional Público: Complexo de normas e acordos que regulamentam os princípios doutrinários aceitos pelos Estados, as relações de amizade e prováveis conflitos porventura surgidos entre ambos, ou seja, seus Direitos e deveres; o mesmo que Direito das Gentes. Comentário: O Direito Internacional Público trata das questões de territórios, nacionalidade, a regulamentação dos mares e do espaço aéreo. A maioria das regras do Direito Internacional Público são estabelecidas pela sua constante repetição e pelos atos permutados entre dois ou mais Estados. Essas regras, quando firmadas em pactos e tratados, ou quando determinadas através de resoluções das organizações internacionais, como a ONU (Organização das Nações Unidas) e OEA (Organização dos Estados Americanos), podem ser transformadas em Leis, regulando atos e ações dos países signatários, ficando estes subordinados aos ditames das Leis por eles pactuadas.

Doutrina: (Lat. doctrina.) S.f. Conjunto de princípios, opiniões, ideias, juízos críticos, conceitos e reflexões teóricas que servem de base a um sistema que os autores expõem e defendem no ensino e interpretação das ciências; como Doutrina jurídica, é aquela formada pelos pareceres dos juristas, nas suas obras, artigos e arrazoados, que exercem real influência na interpretação das normas jurídicas e na apresentação de novos projetos de Lei.

Estado: (Lat. statu.) S.m. Modo de existir na sociedade; situação civil, social ou profissional; divisão administrativa de um país; sociedade politicamente organizada. 
Energia nuclear: é a energia que o núcleo do átomo possui, mantendo prótons e nêutrons juntos. Pode ser liberada por uma reação nuclear uma fissão ou por decaimento radioativo.

Exegese: (Gr. exégesis.) S.f. Explicação, comentário ou dissertação para esclarecimento de um texto de Lei ou outro; o mesmo que hermenêutica jurídica, no caso do exame das Leis.

Exposição: é o ato ou condição de estar submetido à Radiação ionizante.

Exposição anormal: é qualquer ocorrência não previsível com certeza virtual, mas tem uma previsão de que possa ocorrer, ainda que seja indesejável. Ela é expressa por uma probabilidade de ocorrência por ano e uma dose previsível de ocorrer.

Exposição normal: é aquela previsível de ocorrer com virtual certeza durante o trabalho normal da Instalação que opera com fonte de Radiação. Porém, ela também engloba as exposições anormais que tenham probabilidade previsível de ocorrência igual ou maior do que $10^{-2} \mathrm{a}^{-1}$. As exposições normais obrigatoriamente devem obedecer os padrões de radioproteção pertinentes que são: os limites de doses anuais básicos primários e secundários; restrições de dose; doses de Radiação autorizadas e otimizadas e, ainda os níveis de referência.

Exposição potencial: se elas se tornarem reais constituem-se no que se convencionou chamar de Incidente ou acidente nuclear ou radiológico dependendo se ela ocorreu em instalações do ciclo do combustível nuclear, incluindo os reatores, ou se ocorreu em instalações radiativas, isto é, demais instalações não incluídas no ciclo do combustível.

Ilícito: (Lat. illicitu.) Adj. Ato ou ação contrária às Leis ou à moral; que é proibido pelas normas do Direito, da justiça, da moral social, dos bons costumes e da ordem pública. 
Incidente: é quando a Exposição potencial que se torna real permanece confinada na área de propriedade da Instalação e, portanto, infringe unicamente os limites de dose primários e secundários anuais dos trabalhadores.

Incidir: (Lat. incidire.) V.t.d. Cair sobre; sobrevir; acontecer.

Inconstitucionalidade: S.f. Condição contrária aos parâmetros da Constituição. Comentário: Somente o Senado Federal pode suspender, no todo ou em parte, a execução de Lei declarada inconstitucional por decisão definitiva do STF. Também: "Compete ao STF, precipuamente, a guarda da Constituição, cabendoIhe processar e julgar, mediante recurso extraordinário, as causas decididas em única ou última instância, quando a decisão recorrida contrariar dispositivo da Constituição, declarar a Inconstitucionalidade de tratado ou Lei federal; julgar válida Lei ou ato de governo local contestado em face desta Constituição. Podem propor a ação de Inconstitucionalidade: o Presidente da República, a mesa do Senado Federal, da Câmara dos Deputados ou de Assembleia Legislativa; o Governador de Estado; o Procurador-Geral da República; o Conselho Federal da OAB; partido político com representação no Congresso Nacional; confederação sindical ou entidade de classe de âmbito nacional. Declarada a Inconstitucionalidade por omissão de medida para tornar efetiva norma constitucional, será dada ciência ao Poder competente para a adoção das providências necessárias e, em se tratando de órgão administrativo, para fazê-lo em trinta dias. Cabe aos Estados a instituição de representação de Inconstitucionalidade de Leis ou atos normativos estaduais ou municipais em face da Constituição Estadual, vedada a atribuição da legitimação para agir a um único órgão. O Ministério Público tem a função de, entre outras, promover a ação de Inconstitucionalidade ou representação para fins de intervenção da União e dos Estados, nos casos previstos na Constituição.

Instalação nuclear: é a Instalação na qual o material nuclear é produzido, processado, reprocessado, utilizado, manuseado ou estocado em quantidades apreciáveis, assim compreendidos reator nuclear; usina que utilize combustível para a produção de energia térmica ou elétrica para fins industriais; fabrica ou usina para a produção ou tratamento de materiais nucleares integrante do ciclo do 
combustível nuclear; usina de reprocessamento de combustível nuclear irradiado e deposito de materiais nucleares, não incluindo local de armazenamento temporário usado durante os transportes.

Instalação radiativa: é o local onde se produzem, utilizam, transportam ou armazenam fontes de Radiação; excetuam-se desta definição as instalações nucleares e os veículos transportadores de fontes de Radiação quando essas não são parte integrante dos mesmos.

Jurisprudência: (Lat. jurisprudentia.) S.f. Conjunto das soluções dadas pelos tribunais às questões de Direito, segundo Carlos Maximiliano; conjunto de decisões uniformes dos tribunais; autoridade dos casos julgados sucessivamente do mesmo modo; ciência do Direito e dos princípios de Direito seguidos num país, numa dada época ou em certa e determinada matéria legal; fonte secundária do Direito. Observação: Entre os antigos romanos era, na definição de Ulpianu, "divinarum atque humanorum rerum notitia, justi atque injusti scientia" (o conhecimento das coisas divinas e humanas, a ciência do justo e do injusto). Era, portanto, a própria ciência do Direito.

Legislação: (Lat. legislatione.) S.f. Conjunto de Leis; ciência das Leis; sistema legal de um Estado.

Lei: (Lat. lex.) S.f. Norma, regra, princípio constante, prescrição legal; domínio, poder, mando; regra de Direito ditada pela autoridade estatal e tornada obrigatória para manter, numa comunidade, a ordem e o desenvolvimento; norma pela qual o agente usa os meios necessários, reagindo e repelindo agressão a Direito seu ou de terceiro; "Lei é uma ordenação da razão para o bem comum, promulgada por aquele que tem o cuidado da comunidade" (São Tomás de Aquino); "preceito justo, comum e estável, suficientemente promulgado" (Suárez); "Relação necessária entre fenômenos, entre momentos de um processo ou entre Estados de um ser, e que thes expressa a natureza ou a essência"98; Segundo Vampré: "É o preceito escrito, geralmente obrigatório, promulgado e publicado em forma solene, pelo órgão competente do Estado"; Cunha Gonçalves diz que "Lei é uma norma ou um conjunto de normas elaboradas e votadas pelo órgão Legislativo do 
Estado, órgão que pode ser, ora a Assembleia Nacional, ora o governo com a autorização dessa Assembleia ou no exercício normal da função de publicar decretos-Leis, ou de um poder ditatorial ou revolucionário"; segundo Temístocles Cavalcanti, "a Lei, em sua expressão mais geral, é uma forma de que se revestem os atos do Poder Legislativo, manifestação da vontade popular, por meio de órgãos próprios, determinados a ditar as normas gerais por que se devem reger e disciplinar as relações entre os indivíduos e o Estado"; segundo Clóvis Beviláqua, "é a ordem, ou a regra geral obrigatória que, emanando de uma autoridade competente e reconhecida, é imposta coativamente à obediência de todos". Comentário: "As Leis são feitas para organizar a vida em sociedade; para regular a ação das pessoas; para dirimir os conflitos de interesses, os dissídios que surgem na vida prática: destinam-se, pois, a manter a paz, a harmonia entre os homens (...). Para que elas atinjam a sua finalidade, têm que ser aplicadas e é necessário que essa aplicação seja assegurada (...). Tal missão compete à justiça, representada pelos juízes e tribunais, que constituem o poder judiciário" 99 .

Material nuclear: são os elementos químicos nucleares ou subprodutos definidos pela Lei $\mathrm{n}^{\circ} .4 .118$ de 27 de agosto de 1962.

Material radioativo: é o material emissor de qualquer Radiação eletromagnética ou particulada, direta ou indiretamente ionizante.

Norma: S.f. Aquilo que se estabelece como fundamento ou termo para a execução de qualquer coisa; preceito legal, regulamento, modelo.

Norma jurídica: Preceito de Direito concretamente considerado, transformado em prescrição legal; método objetivo da vontade social, manifestada imperativamente a todos pelo Estado, podendo ser: dispositiva, quando apenas anuncia a regra jurídica; interpretativa, quando explica o significado

Programa Nuclear Brasileiro: é o conjunto de projetos e atividades relacionados com a utilização da Energia nuclear, segundo orientação, controle e supervisão do Governo Federal. 
Proteção: entende-se como Proteção aquele efetuada em condições normais de trabalho onde há o respeito aos padrões fixados para este propósito. A Proteção pode ser realizada na própria fonte, geralmente por blindagens adequadas, diz-se relativa à fonte. Pode também ser realizada no meio ambiente, isto é, o ambiente no qual a Radiação se difunde até alcançar o indivíduo. Neste caso, a Proteção é realizada suprimindo uma ou mais vias de transmissão do ambiente ou diminuindo o valor da Radiação no percurso para alcançar o indivíduo. Por fim, pode-se fornecer Proteção ao individuo fornecendo equipamentos de Proteção individial (EPI) radiológica, interpondo barreiras entre ele e o meio ambiente ou ainda por controle remoto.

Proteção física: é o conjunto de medidas destinadas a evitar ato de sabotagem contra material, equipamento e Instalação, a impedir a remoção não autorizada de material desviado, e a defender o patrimônio e a integridade física do pessoal de uma unidade operacional.

Radiação: é a energia que se propaga através da matéria ou do espaço em forma de onda ou partícula.

Radiação ionizante: é qualquer Radiação capaz de "arrancar" elétrons dos átomos, produzindo pares de íons em materiais biológicos.

Radioatividade: é o decaimento espontâneo ou desintegração de um núcleo atômico instável.

Radioisótopo: é o isótopo radioativo. O isótopo instável de um elemento que decai ou se desintegra, emitindo Radiação.

Radioproteção: é o conjunto de medidas legais, técnicas e administrativas que visa, a reduzir a Exposição de seres vivos à Radiação ionizante, a níveis tão pequenos quanto racionalmente exequível.

Rejeitos radioativos: é qualquer material resultante de atividades relacionadas à radionuclídeos (materiais radioativos) em quantidade superiores aos limites 
estabelecidos por normas da CNEN, para o qual a reutilização é imprópria ou não prevista. Comumente emprega-se a expressão lixo atômico como referência ao rejeito radioativo.

Responsabilidade civil: Compromisso de contestar, replicar, retorquir ou dar satisfação pelos próprios atos ou de outra pessoa, ou por uma coisa que lhe foi confiada. "É a capacidade de entendimento ético jurídico e determinação volitiva adequada, que constitui pressuposto penal necessário de punibilidade" ${ }^{\prime 98}$.

Segurança: é uma Proteção destinada a evitar, detectar e tomar as primeiras medidas em situações anormais de operação da fonte, isto é, destina-se a exposições potenciais. Estas são definidas como aquelas exposições que não são esperadas de serem recebidas com certeza, mas que podem resultar de um acidente em uma fonte ou devido a um evento ou sequencia de eventos com uma natureza probabilística, incluindo falhas de equipamento e erros operacionais (falhas humanas). A Segurança é considerada separadamente da Proteção, isto é, fonte, meio e indivíduo. No caso da Segurança a Proteção é realizada por meio do que convencionou chamar de "em profundidade", isto é, a colocação de múltiplas barreiras em distâncias diferentes entre a fonte e o indivíduo. Por exemplo, o reator de pesquisa IEA-R1 do IPEN tem como primeira barreira à piscina do reator, a segunda barreira são as paredes da piscina, como terceira barreira é o prédio do reator que é estanque, a quarta barreira é a portaria que dá acesso ao prédio do reator e laboratórios anexos e finalmente como quinta barreira a portaria geral do IPEN.

Segurança Nuclear: é o conjunto de medidas preventivas de caráter técnico incluídas no projeto, na construção, na manutenção e na operação de unidade operacional do Sistema de Proteção ao Programa Nuclear Brasileiro (SIPRON), destinadas a evitar a ocorrência de acidente ou atenuar o efeito deste.

Seguridade: abrange técnicas, teorias e práticas relacionadas aos sistemas que utilizam fonte de Radiação e de Proteção física das fontes de Radiação, fazendo com que estes atuem de forma segura. Entende-se como segurança física aquela que evita violações de patrimônio e intrusões ilícitas. 
Unidade operacional: é a unidade cuja atividade se relaciona com a produção, utilização, processamento, reprocessamento, manuseio, transporte ou estocagem de materiais de interesse para o Programa Nuclear Brasileiro (PNB).

Unidade de transporte: é o conjunto de meios de transporte, sob chefia única, quando utilizado em proveito de projeto, de atividade ou de Instalação nuclear. 


\section{REFERÊNCIAS BIBLIOGRÁFICAS}

\footnotetext{
${ }^{1}$ Verdugo, M.A. Incidencia del Consejo de Seguridad sobre el regimen juridico de las armas nucleares. E-Book, Bosch Editor, 2007, p. 9-12.

${ }^{2}$ Tennenbaum, J. Energia nuclear uma tecnologia feminina. $2^{\mathrm{a}}$ ed. Rio de Janeiro: Carpax Dei, 2007. p.23-38
}

${ }^{3}$ Coimbra, G.L. A história e o desenvolvimento da energia nuclear no Brasil. In: Nuclear Inter Jura'2001. Proceedings, 2001.p.48-50.

${ }^{4}$ Almeida, I.P.S. Avaliação de fatores que afetam a eficácia de órgãos reguladores: uma aplicação ao setor nuclear. Tese (Doutorado em Tecnologia Nuclear) - Universidade Federal do Rio de Janeiro, 2005. p. 36-40.

${ }^{5}$ Silva, V.A. Interpretação constitucional. São Paulo: Malheiros, 2005.p.54-67.

${ }^{6}$ Bercovici, G. Dilemas do estado federal brasileiro. Porto Alegre: Livraria do Advogado, 2004.p.73-75.

${ }^{7}$ Affonso, R. B. A federação no Brasil: impasses e perspectivas. Revista A Federação em perspectiva: ensaios selecionados. Fundap, 1995. p.27-30.

${ }^{8}$ Barbosa, J.A.M. Contribuição a legislação brasileira no setor de energia nuclear. Tese (Doutorado em Tecnologia Nuclear) - Instituto de Pesquisas Energéticas e Nucleares/Universidade de São Paulo, 2009. p.95.

${ }^{9}$ Machado, P.A.L. Direito Ambiental Brasileiro. 11 ed. São Paulo: Malheiros, 2003. p.57-63.

${ }^{10}$ Vianna, L.W. (Org.). A democracia e os três poderes no Brasil. Rio de Janeiro: IUPERJ, 2003. p.70-75.

${ }^{11}$ Assis, L.G.B. Processo legislativo e orçamento público: a função do controle do Parlamento. Tese (Doutorado em Direito) - Faculdade de Direito da Universidade de São Paulo, 2009. p. 4559.

${ }^{12}$ Vasques, D. Competências legislativas concorrentes: prática legislativa da União e dos Estadosmembros e jurisprudência do Supremo Tribunal Federal. Dissertação (Mestrado em Direito) Faculdade de Direito da Universidade de São Paulo, 2007. p. 49-55.

${ }^{13}$ Almeida, F.D.M. Competências na Constituição de 1988. 4ª ed. São Paulo: Atlas, 2007.p.2541. 
${ }^{14}$ Canotilho, J.J.G. Direito constitucional e teoria da Constituição. $4^{a}$ ed. Coimbra: Almedina, 2000. p.65-68.

${ }^{15}$ Assis, L.G.B. Processo legislativo e orçamento público: a função do controle do Parlamento. Tese (Doutorado em Direito) - Faculdade de Direito da Universidade de São Paulo, 2009. p.5557.

${ }^{16}$ Almeida, F.D.M. Competências na Constituição de 1988. $4^{\mathrm{a}}$ ed. São Paulo: Atlas, 2007. p.4551.

${ }^{17}$ Souto, M.V. Desestatização, privatização, concessões, terceirização e regulamentação. 4.ed. Rio de Janeiro: Lumen Juris, 2001.p.78-90.

${ }^{18}$ Ávila, H. Teoria dos Princípios: da definição à aplicação dos princípios jurídicos. $8^{\text {a }}$ ed. São Paulo: Malheiros, 2008. p. 45-46.

${ }^{19}$ Warat, L.A. Mitos e teorias na interpretação da lei. Porto Alegre: Síntese, 1979.p.12-17.

${ }^{20}$ Häberle, P. Hermenêutica constitucional: a sociedade aberta dos intérpretes da Constituição. Porto Alegre: Fabris, 2004.p.90-95.

${ }^{21}$ Motta, F.M. A função normativa da administração pública brasileira. Tese (Doutorado em Direito) - Faculdade de Direito da Universidade de São Paulo, 2007.p.54-67.

${ }^{22}$ Vieira júnior, R.J.A. O Supremo Tribunal Federal e o controle jurisdicional da atuação do poder legislativo: visão panorâmica e comentada da jurisprudência constitucional. Brasília: Senado Federal, 2007.p.34-65.

${ }^{23}$ Moraes, A. (Coord). Tratados internacionais da Constituição de 1988. In: Amaral, A.C. R. (Coord). Tratados internacionais na ordem jurídica brasileira. São Paulo: Lex editora, 2005. p.31-46.

${ }^{24}$ Tojal, S. Controle judicial da atividade normativa das agências reguladoras. In: Moraes, A (Coord). Agências Reguladoras. São Paulo: Atlas, 2002, p. 162-170.

${ }^{25}$ Ferraz, A.C.C. Mutação, reforma e revisão das normas constitucionais. In: Doutorado em Direito) - Faculdade de Direito da Universidade de São Paulo, 2008.p.67-78.

${ }^{25}$ Bobbio, Norberto. Teoria Geral da Política. Rio de Janeiro: Campus, 2000, p. 218.Cadernos de Direito Constitucional e Ciência política, São Paulo, v.2, n.5, p. 5-24, out/dez.1993.

${ }^{26}$ Martins, J.R. Tutela penal em decorrência das atividades nucleares. Tese (Doutorado em Direito) - Faculdade de Direito da Universidade de São Paulo, 2008.p.67-78.

${ }^{27}$ David, René. Os grandes sistemas do Direito contemporâneo. Trad. Hermínio A. Carvalho. 2. ed. Lisboa: Meridiano, 1972. p.57.

${ }^{28}$ Engelmann. Die Wiedergeburt der Rechtskultur in Italien durch die wissenschaftliche Lehre. Leipzig, 1939. p.16 e ss. apud Alves, José Carlos Moreira. Universidade, cultura e Direito romano. p. 48. Disponível em: http://www.revistas.usp.br/rfdusp/article/viewFile/67166/69776. Acesso em: 25 jan.2016.

${ }^{29}$ Carvalho Netto, Menelick de. A sanção no parlamento legislativo. Belo Horizonte: Del Rey, 1992. p. 26.

${ }^{30}$ Comparato, Fábio Konder. A afirmação histórica dos Direitos Humanos. $4^{\mathrm{a}}$ ed. São Paulo: Saraiva, 2006. p.90. 
${ }^{31}$ Morris, Clarence. et.al. Os grandes filósofos do Direito. Trad. Reinaldo Guarany. São Paulo: Martins Fontes, 2002. p.157.

32 Silva, José Afonso da. Processo constitucional de formação das leis. São Paulo: Saraiva, 2008. p. 79.

${ }^{33}$ Lastra, Arturo Pellet. El poder parlamentário: su origen, apogeo y conflictos. Buenos Aires: Abeledo Perrot, 1995. p.90.

${ }^{34}$ Leal, Victor Nunes. Coronelismo, enxada e voto: o município e o regime representativo no Brasil. $3^{\underline{a}}$ ed. Rio de Janeiro: Nova Fronteira, 1997. p. 81.

${ }^{35}$ Franco, Afonso Arinos de Melo. A Câmara dos Deputados: síntese histórica. Brasília: Câmara dos Deputados, 1976. p.15.

${ }^{36}$ Dallari, Dalmo. Constituição e evolução do estado brasileiro. In: Revista da Faculdade de Direito da Universidade de São Paulo. v. LXXII, 1977. p.325-334.

${ }^{37}$ Skidmore, Thomas E. Uma história do Brasil. 4ª ed. São Paulo: Paz e Terra, 2003. p.107.

${ }^{38}$ Castro, Araújo. A Constituição de 1937. Rio de Janeiro: Livraria Editora Freitas Bastos, 1938. p. 141.

${ }^{39}$ Maximiliano, Carlos. Comentários à Constituição Brasileira. $5^{\text {a }}$ ed. Rio de Janeiro: Freitas Bastos, 1954. 2.v. p.10.

${ }^{40}$ Franco, Afonso Arinos de Melo. A Câmara dos deputados: síntese histórica. São Paulo: Saraiva, 1960. p. 111.

${ }^{41}$ Mendonça, Marina Gusmão de. O demolidor de presidentes. São Paulo: Códex, 2002.p.266.

${ }^{42}$ Fausto, Boris. História do Brasil. 12 ed. São Paulo: Edusp, 2004. p.493.

${ }^{43}$ Santos, Wanderley Guilherme dos. Votos e partidos: almanaque de dados eleitorais - Brasil e outros países. Rio de Janeiro: FGV, 2002. p.13.

${ }^{44}$ Silva, José Afonso da. Curso de Direito constitucional positivo. 10 ed. São Paulo: Malheiros, 1995. p.496.

${ }^{45}$ Bastos, Celso Ribeiro. Curso de Direito constitucional. 21. ed. São Paulo: Saraiva, 1999. p. 357.

${ }^{46}$ Lenza, Pedro. Direito constitucional esquematizado. 18. ed. rev., atual. e ampl. São Paulo: Saraiva, 2014. p. $469-472$.

${ }^{47}$ Temer, Michel. Elementos do Direito Constitucional. 10ª ed. São Paulo: Malheiros, 1993. p. 77.

${ }^{48}$ Kelsen, Hans. Teoria Geral do Direito e do Estado. $2^{\text {a }}$ ed. Tradução de Luís Recaséns Siches e Justino de Azcárate. Barcelona: Bosch, 1934. p. 435.

${ }^{49}$ Almeida, Fernanda Dias Menezes de. Competências na Constituição de 1988. $4^{\text {a }}$ ed. São Paulo: Atlas, 2007. p.103.

${ }^{50}$ Ferraz, Anna Cândida da Cunha. Poder constituinte dos Estados-membros. São Paulo: Revistas dos Tribunais, 1979. p.150-151. 
${ }^{51}$ Ferraz Junior, Tércio Sampaio. Princípios Condicionantes do Poder Constituinte. Revista de Direito Público №.92, 1989. P. 35-42.

${ }^{52}$ Almeida, Fernanda Dias Menezes de. Competências na Constituição de 1988. $4^{\underline{a}}$ ed. São Paulo: Atlas, 2007.p.96.

${ }^{53}$ Rocha, Carmen Lúcia Antunes. República e Federação no Brasil. Belo Horizonte: Del Rey, 1997. P. 291-292

${ }^{54}$ Bercovici, Gilberto. Dilemas do Estado Federal Brasileiro. Porto Alegre: Livraria do Advogado, 2004. P. 59-60.

${ }^{55}$ Marques Neto, Floriano Azevedo. A nova regulamentação dos serviços públicos. Revista eletrônica de Direito Administrativo econômico, nº. 01, fev. 2005b, Salvador.

${ }^{56}$ Araújo, Luiz Alberto David; Nunes Junior, Vidal Serrano. Curso de Direito constitucional. 13 ed. São Paulo: Saraiva, 2009.p. 274-275.

${ }^{57}$ Antunes, Paulo de Bessa. Direito Ambiental. Rio de Janeiro: Lumen Juris, 1996. p.68.

${ }^{58}$ Brasil, Lei no. 6.189 de 16 de dezembro de 1974. Altera a Lei no 4.118, de 27 de agosto de 1962, e a Lei no 5.740 , de 1 de dezembro de 1971, que criaram, respectivamente, a Comissão Nacional de Energia Nuclear - CNEN e a Companhia Brasileira de Tecnologia Nuclear - CBTN, que passa a denominar-se Empresas Nucleares Brasileiras Sociedade Anônima - NUCLEBRÁS, e dá outras providências.

${ }^{59}$ Mendes, Gilmar Ferreira; Coelho, Inocêncio; Branco, Paulo G.. Curso de Direito constitucional. São Paulo: Saraiva, 2007. p. 49

${ }^{60}$ Barroso, Luis Roberto (Org). A nova interpretação constitucional: ponderação, Direitos fundamentais e relações privadas. Rio de Janeiro: Renovar, 2003. p. 29-30.

${ }^{61}$ Bonavides, Paulo. Curso de Direito Constitucional. 15 ${ }^{\mathrm{a}}$ ed. São Paulo: Malheiros, 2003. p. 131.

${ }^{62}$ Figueiredo Neto, Diogo. Competência concorrente limitada. O problema da conceituação das normas gerais. Revista de Informação Legislativa. Brasília, v. 25, n. 100, out./dez;1988. p. 149150.

${ }^{63}$ Araújo, Marcelo Labanca C. de. O condomínio legislativo. Dissertação (Mestrado em Direito Constitucional). Universidade Federal de Pernambuco, Recife, 2001, p. 111-112.

${ }^{64}$ Resek, José Francisco. Direito Internacional público. $7^{\text {a }}$ ed. São Paulo: Saraiva, 1998. p.1-3.

${ }^{65}$ Brasil. Constituição da República Federativa do Brasil. Art.173.

${ }^{66}$ Torres, Sílvia Faber. O Princípio da Subsidiariedade no Direito Público Contemporâneo. Rio de Janeiro: Renovar, 2001. p. 157-158.

${ }^{67}$ Grau, Eros Roberto. A Ordem Econômica na Constituição de 1988. 13a ed. São Paulo: Malheiros Editores, 2008. p. 147.

${ }^{68}$ Brasil, Lei no. 6.453 de 17 de outubro de 1977. Dispõe sobre a responsabilidade civil por danos nucleares e a responsabilidade criminal por atos relacionados com atividades nucleares e dá outras providências.

${ }^{69}$ Bastos, Celso Ribeiro; Martins, Ives Gandra. Comentários a Constituição do Brasil. São Paulo: Saraiva, 1993. 3.v. p. 321-323. 
70 Disponível em: http://pt.euronews.net/2006/06/03/reforma-do-federalismo-aprovada-pelobundestag/. Acesso em: 08 jul.2016.

${ }^{71}$ Lobo, Paulo Luiz Neto. Competência legislativa concorrente dos estados-membros na Constituição de 1988. Revista de Informação Legislação. Brasília, v.26. n. 101, jan./mar.1989.

${ }^{72}$ Ferraz, Anna Cândida da Cunha. União, Estados e municípios na Nova Constituição: enfoque jurídico-formal. A nova Constituição Paulista. São Paulo: Fundação Faria Lima/ Fundação de desenvolvimento Administrativo, 1989. p.54.

${ }^{73}$ Brasil, Lei no. Lei no. 10.308 de 20 de novembro de 2001. Dispõe sobre a seleção de locais, a construção, o licenciamento, a operação, a fiscalização, os custos, a indenização, a responsabilidade civil e as garantias referentes aos depósitos de rejeitos radioativos, e dá outras providências.

${ }^{74}$ Brasil, Decreto s/n de 02 de julho de 2008. Cria o Comitê de Desenvolvimento do Programa Nuclear Brasileiro.

${ }^{75}$ Amorim, Claudia Nóbrega de Andrade. Regime jurídico das atividades nucleares. Disponível em: https://www.agu.gov.br/page/download/index/id/1096549. Acesso em: 28 mar.2016.

${ }^{76}$ Sidou, J.M.O.. Dicionário Jurídico: acadêmia brasileira de letras jurídicas. $8^{\underline{a}}$ ed. Rio de Janeiro: Forense Universitária, 2003. p.98; 239.

${ }^{77}$ Nader, Paulo. Introdução ao Estudo do Direito. 21. ed., Rio de Janeiro: Forense, 2001, p. 81.

${ }^{78}$ Machado Neto, A. L. Compêndio de Introdução à Ciência do Direito. 5. ed. São Paulo: Saraiva, 1984, p. 202 apud DINIZ, Maria Helena. Compêndio de Introdução ao Estudo do Direito. 17. ed., à luz da Lei n. 10.406 /02, São Paulo: Saraiva, 2005, p. 294.

${ }^{79}$ Morris, Clarence. et.al. Os grandes filósofos do Direito. Trad. Reinaldo Guarany. São Paulo: Martins Fontes, 2002. p.157

${ }^{80}$ Carvalho, José Murilo de. D. Pedro II. São Paulo: Cia. das Letras, 2007. p.126.

${ }^{81}$ Lenza, Pedro. Direito constitucional esquematizado. 18. ed. rev., atual. e ampl. São Paulo: Saraiva, 2014. p. $469-472$.

${ }^{82}$ Brasil, Constituição da República Federativa do Brasil de 1988.

${ }^{83}$ Brasil, Supremo Tribunal Federal. Ação Direita de Inconstitucionalidade no. 97/RO. Relator: Ministro Moreira Alves. Brasília, 25 de junho de 1993. Brasília, 22 de outubro de 1993, v. 0257402, p. 00287. Disponível em:

http://redir.stf.jus.br/paginadorpub/paginador.jsp?docTP=AC\&docID=266192. Acesso em: 16 de jul. 2016.

${ }^{84}$ De Plácido e Silva. Vocabulário Jurídico. Rio de Janeiro: Forense, 2012.p.225.

${ }^{85}$ Disponível em: http//: www.stf.jus.br/jurisprudência. Acesso em: 05 ago.2016 as 16h35.

${ }^{86}$ Frois, Fernanda. O Direito Nuclear e os acidentes radiológicos. VI CGEN - Congresso Nacional de Energia Nuclear, 1996.

${ }^{87}$ Torres, Sílvia Faber. O Princípio da Subsidiariedade no Direito Público Contemporâneo. Rio de Janeiro: Renovar, 2001. p. 157-158. 
${ }^{88}$ Brasil, Lei no. 6.453 de 17 de outubro de 1977. Dispõe sobre a responsabilidade civil por danos nucleares e a responsabilidade criminal por atos relacionados com atividades nucleares e dá outras providências.

${ }^{89}$ Brasil, Lei no. 6.189 de 16 de dezembro de 1974. Altera a Lei ํo 4.118, de 27 de agosto de 1962, e a Lei no 5.740, de 1 de dezembro de 1971, que criaram, respectivamente, a Comissão Nacional de Energia Nuclear - CNEN e a Companhia Brasileira de Tecnologia Nuclear - CBTN, que passa a denominar-se Empresas Nucleares Brasileiras Sociedade Anônima - NUCLEBRÁS, e dá outras providências.

${ }^{90}$ Brasil, Dicionário Aurélio da Língua Portuguesa. Disponível em:

https://dicionariodoaurelio.com/. Acesso em: 17 abr. 2016.

${ }^{91}$ Ferreira Filho, Manoel Gonçalves. Comentários a Constituição Brasileira de 1988. São Paulo: Saraiva, 1990. 1.v. p.203.

${ }^{92}$ Brasil, Constituição Estadual do Rio Grande do Norte.

${ }^{93}$ Brasil, Lei no. 10.308 de 20 de novembro de 2001. Dispõe sobre a seleção de locais, a construção, o licenciamento, a operação, a fiscalização, os custos, a indenização, a responsabilidade civil e as garantias referentes aos depósitos de rejeitos radioativos, e dá outras providências.

${ }^{94}$ Brasil, Constituição Estadual de Goiás.

${ }^{95}$ Brasil, Lei no. 6.803 de 2 de julho de $\mathbf{1 9 8 0}$. Dispõe sobre as diretrizes básicas para o zoneamento industrial nas áreas críticas de poluição, e dá outras providências.

${ }^{96}$ Antunes, Paulo de Bessa. Federalismo e competências ambientais no Brasil. Rio de Janeiro: Lumen Juris, 2007. P. 225.

${ }^{97}$ Conotilho, J.J. Direito Constitucional. Coimbra: Liv. Almedina, 1981, v. II, p. 11 e 12.

${ }^{98}$ Ferreira, Aurélio Buarque de Holanda. Novo Dicionário Aurélio da Língua Portuguesa. 3. ed. Rio de Janeiro: Nova Fronteira, 1999.

${ }^{99}$ Lima, J. Franzen de. Curso de Direito civil brasileiro, § VII: interpretação das Leis. Rio de Janeiro: Forense,2006. v. 1, p. 109. 